Florida International University FIU Digital Commons

$10-31-2013$

\title{
Influence of Soil Biogeochemical Properties on the Invasiveness of Old World Climbing Fern (Lygodium microphyllum)
}

Pushpa Gautam Soti

psoti001@fiu.edu

DOI: $10.25148 /$ etd.FI13120201

Follow this and additional works at: https://digitalcommons.fiu.edu/etd

Part of the Plant Biology Commons, and the Terrestrial and Aquatic Ecology Commons

\section{Recommended Citation}

Soti, Pushpa Gautam, "Influence of Soil Biogeochemical Properties on the Invasiveness of Old World Climbing Fern (Lygodium microphyllum)" (2013). FIU Electronic Theses and Dissertations. 960.

https://digitalcommons.fiu.edu/etd/960 


\title{
FLORIDA INTERNATIONAL UNIVERSITY
}

Miami, Florida

\section{INFLUENCE OF SOIL BIOGEOCHEMICAL PROPERTIES ON THE INVASIVENESS OF OLD WORLD CLIMBING FERN (LYGODIUM MICROPHYLLUM)}

\author{
A dissertation submitted in partial fulfillment of \\ the requirements for the degree of \\ DOCTOR OF PHILOSOPHY \\ in \\ GEOSCIENCES \\ by \\ Pushpa Gautam Soti
}


To: Dean Kenneth G. Furton

College of Arts and Sciences

This dissertation, written by Pushpa Gautam Soti, and entitled Influence of Soil Biogeochemical Properties on the Invasiveness of Old World Climbing Fern (Lygodium microphyllum), having been approved in respect to style and intellectual content, is referred to you for judgment.

We have read this dissertation and recommend that it be approved.

Florentin Maurrasse

Joel Heinen

Michael Sukop

Suzanne Koptur

Krishnaswamy Jayachandran, Major Professor

Date of Defense: October 31, 2013

The dissertation of Pushpa Gautam Soti is approved.

$\begin{array}{r}\begin{array}{r}\text { Dean Kenneth G. Furton } \\ \text { College of Arts and Sciences }\end{array} \\ \hline \begin{array}{r}\text { Dean Lakshmi N. Reddi } \\ \text { University Graduate School }\end{array}\end{array}$

Florida International University, 2013 
(C) Copyright 2013 by Pushpa Gautam Soti

All rights reserved. 


\section{ACKNOWLEDGMENTS}

I am thankful to the Earth and Environment Department at Florida International University for giving me the opportunity to pursue graduate studies and providing the research facilities. I would like to express a heartfelt thank you to my advisor Dr. Krish Jayachandran, for his interest, advice, guidance and support during the study and encouraging kind words when I was in difficult situations. Many thanks to all my committee members Dr. Mike Sukop, Dr. Florentin Maurrasse, Dr. Joel Heinen and Dr. Suzanne Koptur for their consistent support and constructive criticism. Thanks to my collaborators, Dr. John Volin, Dr. Matthew Purcell, Dr. Kaouru Kitajima, for all the time and energy they put into helping me with my research and manuscripts. It was a great pleasure to work with you all.

I would like to thank Dr. Matthew Purcell, USDA ARS Australian Biological Control Laboratory, Cheryl Millett, Central Florida Nature Conservancy, for collecting the samples and shipping them overnight, free of cost. Thanks to Patricia L. Howell, Natural Areas Specialist, Broward County, and Jeffrey Bach Environmental Specialist, Jonathan Dickinson State Park, for their help in sample collection. Many thanks to Dr. Steven Oberbauer, Professor, Department of Biological Sciences, and Dr. Steward Reed, USDA, ARS for letting me use their equipment.

I would also like to acknowledge the University Graduate School of FIU for awarding the Doctoral Evidence Acquisition Fellowship. I would like to thank Dr. Kateel Shetty, Randy Juste, Seema Sha and Diane Pirie for their help in the lab. I extend my appreciation to statistical consultants at FIU for their help in verifying my methods and 
SAS codes. I am also thankful to the Agroecology lab, administrative staff, classmates and friends at FIU, it was fun to be around with you guys.

Finally and most dearly, I would like to thank my husband, Bimal Soti, my boys Bipul Soti and Alok Soti, my entire family and friends for cheering me up and standing by me in good time and bad. 


\begin{abstract}
OF THE DISSERTATION
INFLUENCE OF SOIL BIOGEOCHEMICAL PROPERTIES ON THE

INVASIVENESS OF OLD WORLD CLIMBING FERN (LYGODIUM
\end{abstract}

MICROPHYLLUM)

\author{
by \\ Pushpa Gautam Soti \\ Florida International University, 2013 \\ Miami, Florida \\ Professor Krishnaswamy Jayachandran, Major Professor
}

The state of Florida has one of the most severe exotic species invasion problems in the United States, but little is known about their influence on soil biogeochemistry. My dissertation research includes a cross-continental field study in Australia, Florida, and greenhouse and growth chamber experiments, focused on the soil-plant interactions of one of the most problematic weeds introduced in south Florida, Lygodium microphyllum (Old World climbing fern). Analysis of field samples from the ferns introduced and their native range indicate that $L$ microphyllum is highly dependent on arbuscular mycorrhizal fungi (AMF) for phosphorus uptake and biomass accumulation. Relationship with AMF is stronger in relatively dry conditions, which are commonly found in some Florida sites, compared to more common wet sites where the fern is found in its native Australia. In the field, L. microphyllum is found to thrive in a wide range of soil $\mathrm{pH}$, texture, and nutrient conditions, with strongly acidic soils in Australia and slightly acidic soils in Florida. Soils with pH 5.5 - 6.5 provide the most optimal growth conditions for L. microphyllum, and the growth declines significantly at soil $\mathrm{pH} 8.0$, indicating that further reduction 
could happen in more alkaline soils. Comparison of invaded and uninvaded soil characteristics demonstrates that L. microphyllum can change the belowground soil environment, with more conspicuous impact on nutrient-poor sandy soils, to its own benefit by enhancing the soil nutrient status. Additionally, the nitrogen concentration in the leaves, which has a significant influence in the relative growth rate and photosynthesis, was significantly higher in Florida plants compared to Australian plants. Given that L. microphyllum allocates up to $40 \%$ of the total biomass to rhizomes, which aid in rapid regeneration after burning, cutting or chemical spray, hence management techniques targeting the rhizomes look promising. Over all, my results reveal for the first time that soil $\mathrm{pH}$, texture, and AMF are major factors facilitating the invasive success of L. mcirophyllum. Finally, herbicide treatments targeting rhizomes will most likely become the widely used technique to control invasiveness of L. microphyllum in the future. However, a complete understanding of the soil ecosystem is necessary before adding any chemicals to the soil to achieve a successful long-term invasive species management strategy. 


\section{TABLE OF CONTENTS}

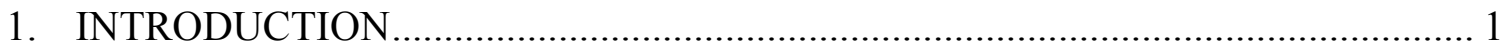

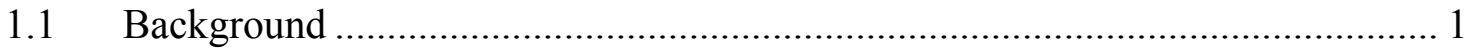

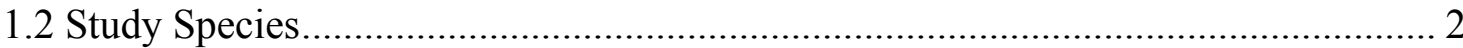

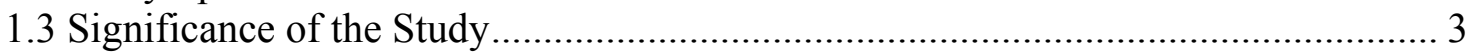

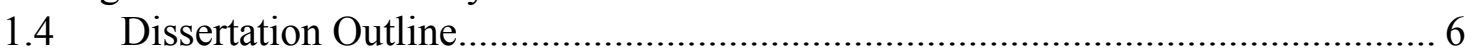

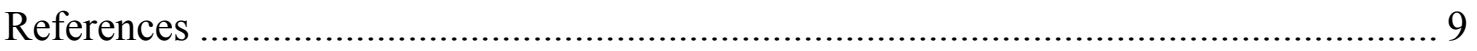

2. MYCORRHIZAL SYMBIOSIS AND LYGODIUM MICROPHYLLUM INVASION IN SOUTH FLORIDA - A BIOGEOGRAPHIC COMPARISON .............. 11

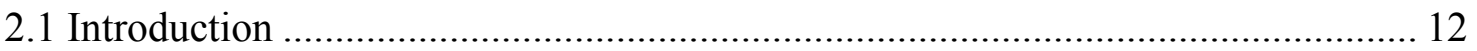

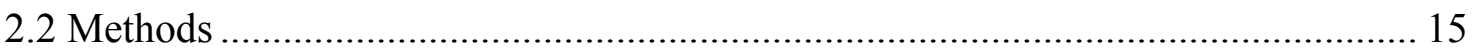

2.2.1 Experiment 1: Degree of mycorrhizal colonization in L. microphyllum........... 15

2.2.2 Experiment 2: Mycorrhizal dependency of L. microphyllum ……………....... 17

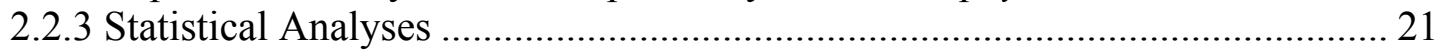

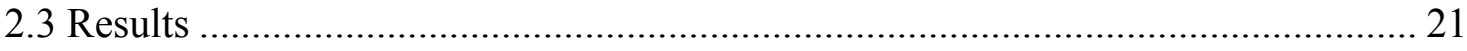

2.3.1 Degree of mycorrhizal colonization and influence of soil factors .................... 21

2.3.2 Mycorrhizal dependency ........................................................................ 26

2.4 Discussion and Conclusion............................................................................ 28

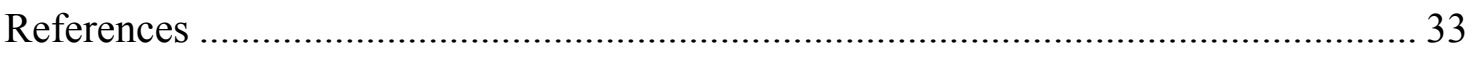

3. EFFECT OF SOIL $\mathrm{pH}$ ON GROWTH, NUTRIENT UPTAKE, AND MYCORRHIZAL COLONIZATION IN EXOTIC INVASIVE LYGODIUM

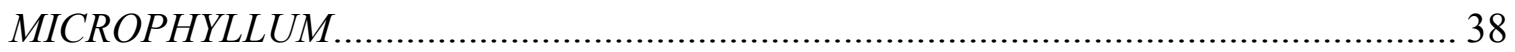

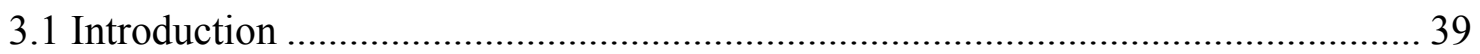

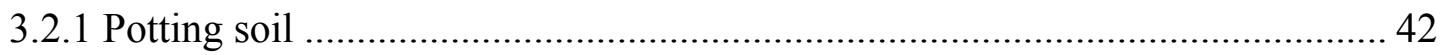

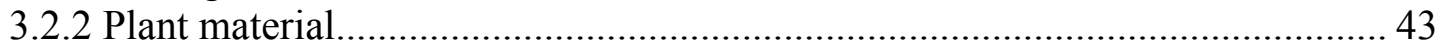

3.3.3 Harvest and plant nutrient analysis ............................................................ 44

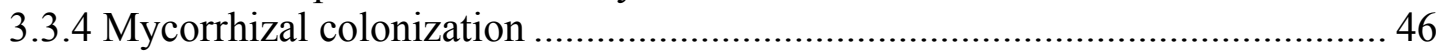

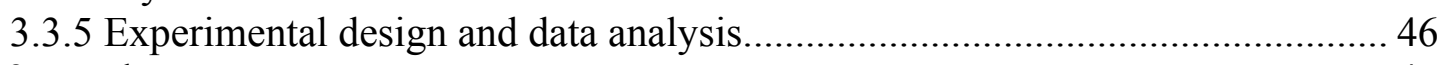

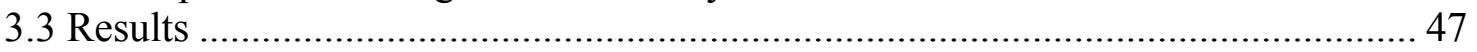

3.3.1 Element concentration and uptake ............................................................. 49

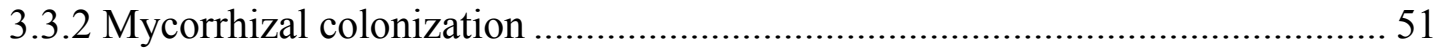

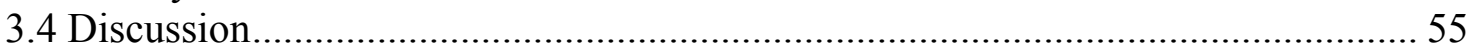

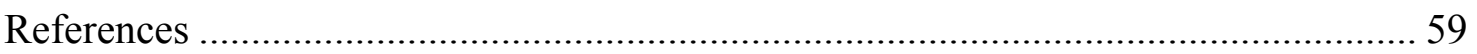

4. ALTERED SOIL BIOGEOCHEMICAL PROPERTIES BY EXOTIC INVASIVE OLD WORLD CLIMBING FERN (LYGODIUM MICROPHYLLUM) IN FLORIDA: IMPLICATIONS FOR MANAGEMENT AND RESTORATION …………………..... 64

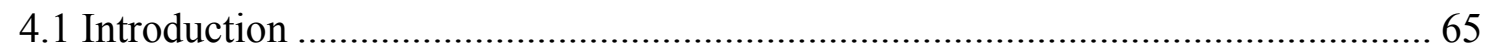

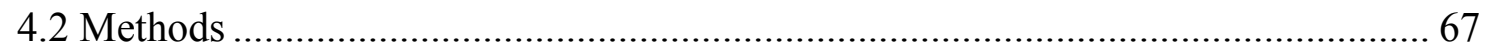

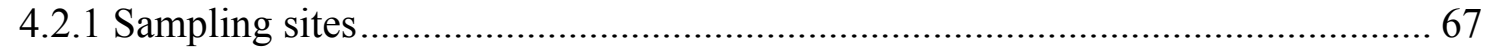




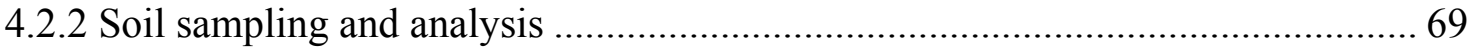

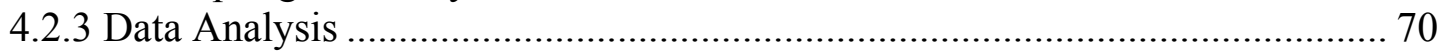

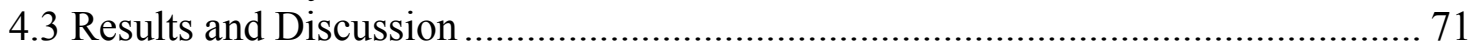

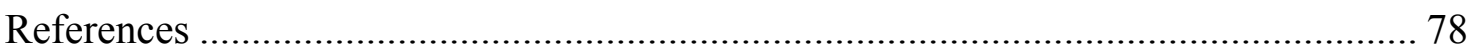

5. INFLUENCE OF SOIL BIOGEOCHEMICAL PROPERTIES ON EXOTIC INVASIVE LYGODIUM MICROPHYLLUM: A CROSS CONTINENT COMPARISON OF SOIL CHARACTERISTICS TO INVASION SUCCESS .................................... 81

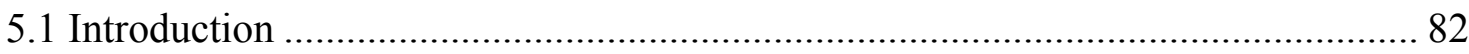

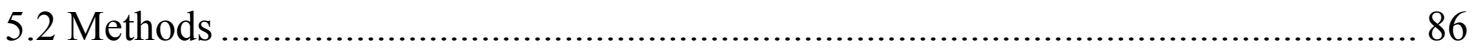

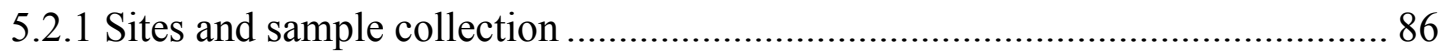

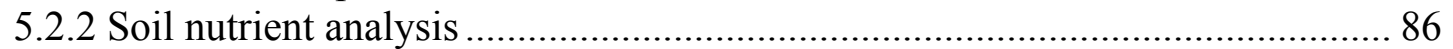

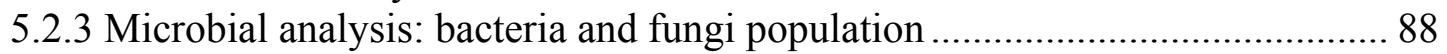

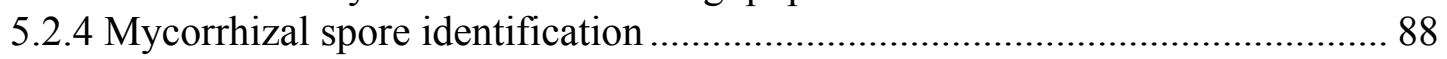

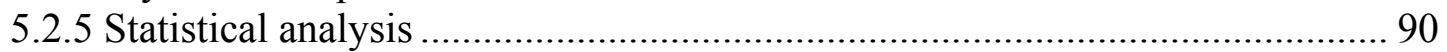

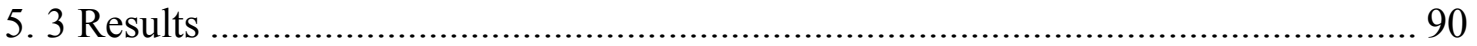

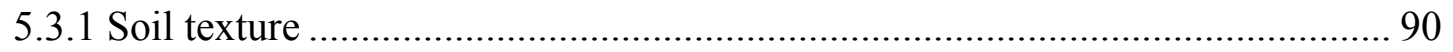

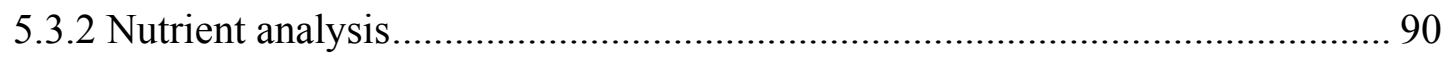

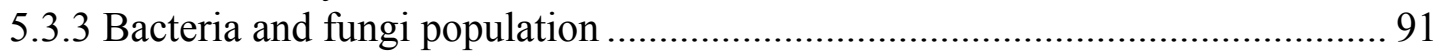

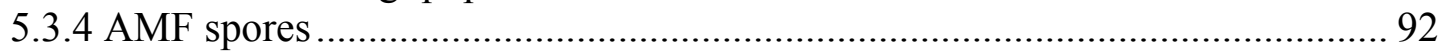

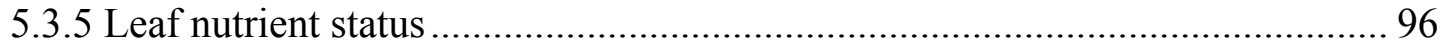

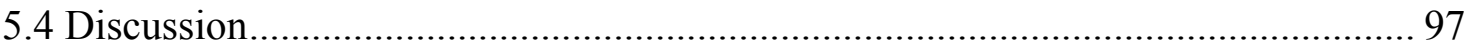

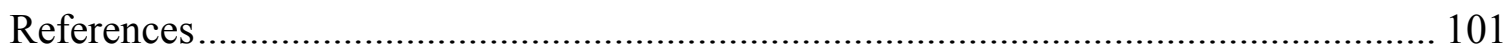

6. CONCLUSIONS AND RECOMMENDATIONS ........................................... 104

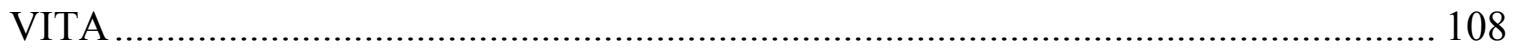




\section{LIST OF TABLES}

TABLE

PAGE

Table 2.1 Sampling site information with the number of AMF spores and mycorrhizal colonization.

Table 2.2 Effect of arbuscular mycorrhizal fungi (AMF) inoculation on plant growth parameters and on leaf content of biolimiting elements ( $\mathrm{P}$ and $\mathrm{N})$.

Table 3.1 Rates of application of $\mathrm{Ca}(\mathrm{OH})_{2}$ and elemental $\mathrm{S}$ for $\mathrm{pH}$ adjustment of the experimental soils

Table 3.2 Effect of soil $\mathrm{pH}$ on element concentration (mean \pm std. dev.) in the leaf tissue of L. microphyllum.....

Table 3.3 Correlation coefficients of plant growth parameters and leaf element concentration with the degree of mycorrhizal colonization.

Table 4.1 Site locations, vegetation, and site type.

Table 4.2 Comparison of the topsoil characteristics (means with standard deviations in

parentheses) at the three sites with and without L. microphyllum.

Table 4.3 Results of two-way analyses of variance (ANOVA) with degree of freedom (DF), F-value and probability levels for the effects of site, plant type and the interaction of the two on the soil characteristics.

Table 4.4 Pearson's correlation coefficients between the selected soil parameters with all sites pooled

Table 5.1 Sampling sites, dominant vegetation and date of sample collection for the two continents.

Table 5.2 Soil texture and mean \pm standard error of the means of total colony forming units (counts $\times 107$ ) of bacteria; (count $\times 10^{3}$ ) of fungi per gram of soil in the invaded and native sites. 


\section{LIST FIGURES}

FIGURE

PAGE

Figure 1.1 Native, introduced, and predicted distribution of Lygodium microphyllum (Adapted from Volin et al., 2009, with permission from Springer).

Figure 1.2 Increase in the distribution of Lygodium microphyllum in Florida from 1993 to 2010, data source: Florida Exotic Pest Plant Council (FLEPPC)...................................... 6

Figure 2.1 Means ( $\pm \mathrm{SE}$ ) of soil nutrients: a) total soil phosphorus (mg g-1); b) total soil nitrogen \%; c) total soil carbon (\%)...................................................................... 23

Figure 2.2 Arbuscular mycorrhizal fungal structures (a), vesicles and fungal hyphae (b), in root cortex region of South Florida Plants, vesicles and fungal hyphae in the root cortex region of Australian plants (c). 24

Figure 3.1 Mean ( $( \pm \mathrm{SE})$ final biomass (a); mean $( \pm \mathrm{SE})$ relative growth rate (RGR) (b); mean $( \pm \mathrm{SE})$ root mass ratio (RMR) (c) and mean $( \pm \mathrm{SE})$ rhizome mass ratio (RhiMR) (d), measured at the end of 60 days in four different soil $\mathrm{pH}$ levels. Similar letters represent no significant difference at $P<0.05$. 48

Figure 3.2 Mean value $( \pm \mathrm{SE}$ ) of degree of mycorrhizal colonization at different $\mathrm{pH}$ levels. Similar letters represent no significant difference at $p \leq 0.05$. 52

Figure 3.3 Mean $( \pm \mathrm{SE})$ value specific leaf area (SLA) at different $\mathrm{pH}$ levels. Similar letters represent no significant difference at $\mathrm{p} \leq 0.05$. 53

Figure 3.4Mean ( $\pm \mathrm{SE}$ ) value of area based photosynthesis (a), mass based photosynthesis (b) at different $\mathrm{pH}$ levels. Similar letters represent no significant difference at $\mathrm{p} \leq 0.05 .53$

Figure 3.5 Linear regression of leaf nitrogen concentration and (a) total biomass, (b) specific leaf area (SLA); (c) relative growth rate (RGR); (d) area based photosynthesis $\left(\mu \mathrm{mol} \mathrm{m} \mathrm{s}^{-1}\right)$ 54

Figure 5.1World soil $\mathrm{pH}$ map,data source ISRIC-Wise world dataset. 85

Figure 5. 2 AMF morphotypes extracted from the rhizosphere soil of L. microphyllum in the two continents. Glomus sp. spore (a, e, f); Gigaspora sp. with the bulbous sporangeneous cell ( $\mathrm{h}, \mathrm{j})$; Scutellospora sp. showing the germination shield (b, d, g, i). 93

Figure 5.3 Nutrient concentration in the leaves (Mean $\pm \mathrm{S}$ E) of L. microphyllum collected from different sites. For $\mathrm{N}$ and $\mathrm{P}$ separately, different letters indicate significant differences in leaf concentration of $\mathrm{N}$ and $\mathrm{P}(\mathrm{P}<005$; Tukey's test $)$. 96 


\section{ABBREVIATIONS AND ACRONYMS}

\section{ABBREVIATIONS/ \\ ACRONYMS}

$\mathrm{Al}$

AMF

C

$\mathrm{Ca}$

$\mathrm{Cu}$

CFU

DI

$\mathrm{Fe}$

FLEPPC

K

LMR

$\mathrm{Mg}$

$\mathrm{Mn}$

$\mathrm{N}$

$\mathrm{OM}$

$\mathrm{P}$

RPM

RGR

RhiMR

RMR

SLA

SMR

$\mathrm{Zn}$

\section{DESCRIPTION}

Aluminum

Arbuscular mycorrhizal fungi

Carbon

Calcium

Copper

Colony forming units

Deionized

Iron

Florida Exotic Pest Plant Council

Potassium

Leaf mass ratio

Magnesium

Manganese

Nitrogen

Organic matter

Phosphorus

Rounds per minute

Relative growth rate

Rhizome mass ratio

Root mass ratio

Specific leaf area

Stem mass ratio

Zinc 


\subsection{Background}

\section{INTRODUCTION}

Invasive species are among the major factors affecting the integrity and function of ecosystems worldwide (Reid and Miller 1989; Williamson 1996; Luken and Thieret 1997). Invasive species are characterized by their adaptability to various habitats, increased competitiveness, higher reproductive potential and lack of natural predators to limit their extensive growth. Along with economic loss, invasive species cause significant loss of ecosystem stability, functional complexity and biodiversity (Gordon 1998; Williams and West 2000) because the biological interactions in the rhizosphere play a significant role in plant growth, ecosystem productivity and vegetation dynamics (Brussaard et al., 2001). Individual species have been shown to affect a variety of components of the carbon (C) and nutrient cycles, including pools of aboveground and belowground $\mathrm{C}$, nitrogen $(\mathrm{N})$, and other elements; net primary productivity and plant growth rates; chemical quality and rates of litter fall; and nutrient and $\mathrm{C}$ mineralization rates (Tilman et al., 1997; Hooper and Vitousek 1998; van Breeman 1998; Hector et al., others 1999; Chapin et al., 2000). This body of evidence strongly suggests that when the species composition of a community changes because of the invasion and spread of an exotic species, there are likely to be consequent changes in nutrient cycling processes.

The state of Florida has one of the most severe invasive exotic species problems in the United States. According to Wunderlin (1998), non-native species make up 33\% of all the plants found growing out of cultivation in Florida, and the 
Florida Exotic Pest Plant Council (FLEPPC) considers 152 of these naturalized plants to be invasive to some degree as they are altering native plant communities by displacing native plant species, changing community structures or ecological functions or hybridizing with native plant species (Langeland and Hutchinson 2013).

\subsection{Study Species}

Lygodium microphyllum (Cav.) R. Br., native to Asia and Australia (Fig. 1.1) invades many freshwater and moist habitats in Florida, and is common in cypress swamp, pine flatlands, wet prairies, sawgrass marshes, mangrove communities, and Everglades tree islands (Pemberton and Ferriter, 1998). Lygodium microphyllum with its ability to form dense mats, spreads very rapidly and dominates both understory and overstory native wetland habitats. It has the ability to grow in varying hydrological (Gandiaga et al., 2009) and light gradients (Pemberton et al., 2002). Fire, which is not a very effective method (Maithana et al., 1986), is the most commonly used technique to control $L$. microphyllum. It is reported that has the ability to alter the fire ecology in the Everglades, prescribed burning which normally stop at the margins of flooded cypress sloughs, but in L. microphyllum infested areas enters the tree canopy through the mats of L. microphyllum (Ferriter et al., 2005) thus causing the loss of some canopy trees as well as a loss of native epiphytes and bromeliads residing on tree trunk (Roberts, 1996). Lygodium microphyllum spreads quickly in the South Florida's landscape because of its ability to reproduce through the three mating systems possible in a fern: intra- and intergametophytic selfing and out-crossing (Lott et al., 2003). Spores can germinate in six to 
seven days (Brown, 1984). Lygodium microphyllum is now spreading rapidly throughout Southern Florida (Fig. 1.2). By 1997 it had covered 15,800 hectares and by 1999 it spread to more than 43,000 hectares (Pemberton and Ferriter, 1998; Ferriter et al., 2005). According to a model developed by Volin et al., (2004), the landscape coverage of $L$. microphyllum infestations could exceed the current combined coverage of the top five invasive species by 2014. Volin et al., (2010) have suggested that the belowground microbial community can influence the establishment of L. microphyllum in south Florida and contribute to its invasiveness. Thus the role of belowground ecology in invasions by exotic plants cannot be overlooked and need to be addressed to achieve sustainable management of exotic invasive species in the Everglades.

\subsection{Significance of the Study}

The current management techniques: fire, herbicides, and mechanical removal, are inadequate and the prospect of developing a method that targets the rhizomes of $L$. microphyllum is compelling; however, the soil biogeochemical characteristics of $L$. microphyllum infested sites remain unexplored. Before we target the rhizomes, it is imperative to elucidate the soil characteristics of the sites (both infested and uninfested) to obtain baseline information. Additionally, it is also important to gain information of the soil characteristics of the native range where this plant has its origin and adapted habitat. Thus, I did a detailed cross continental study on the soil biogeochemical properties of the recipient habitat in Florida and native range in Australia. The results from my study will assist in better understanding of the complex feedbacks between exotic invasive plants, soil microbial community and soil elements. It will further provide 
opportunities to land managers and researchers to develop a successful integrated management technique. 


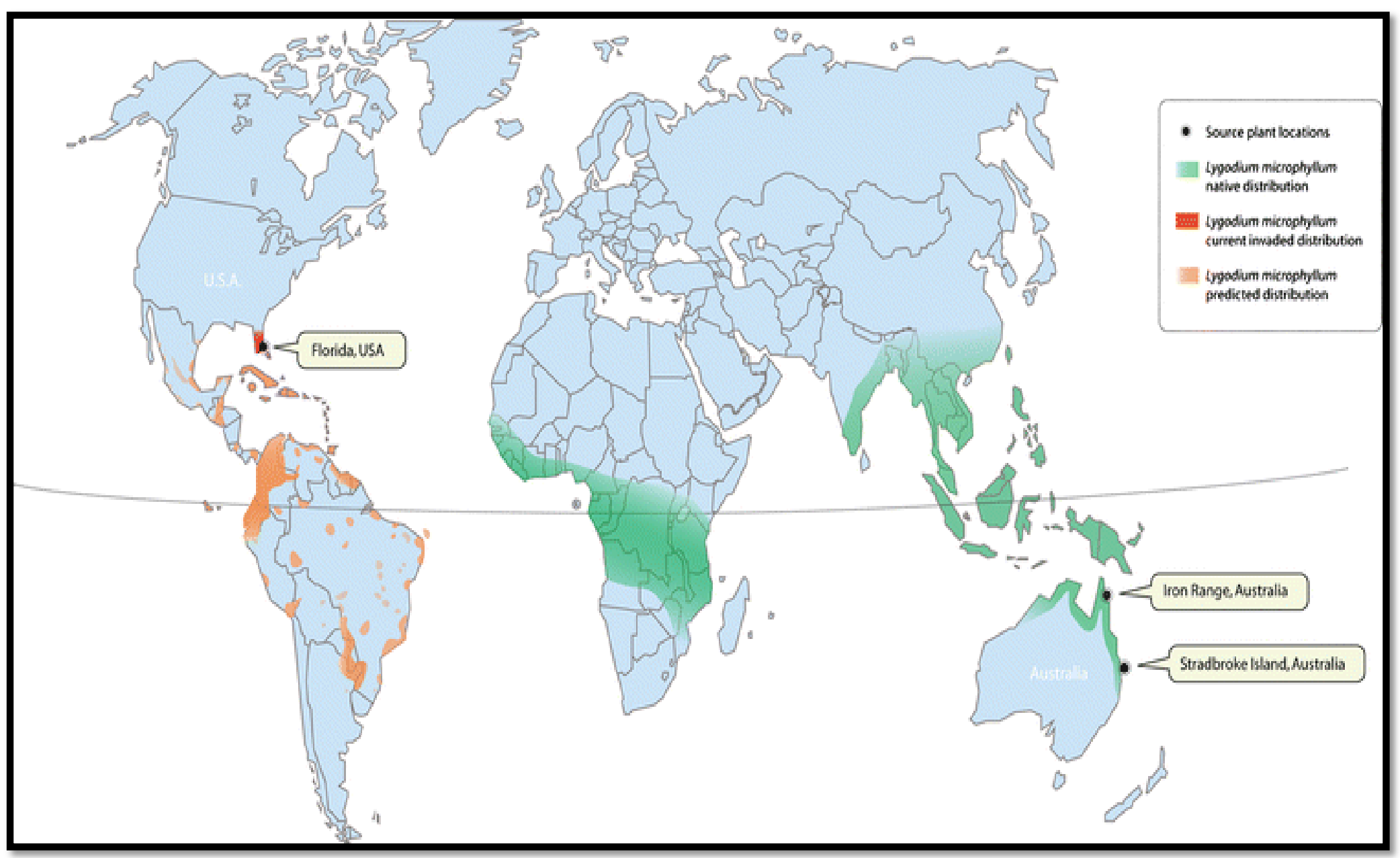

Figure 0.1 Native, introduced, and predicted distribution of Lygodium microphyllum (Adapted from Volin et al., 2009, with permission from Springer). 


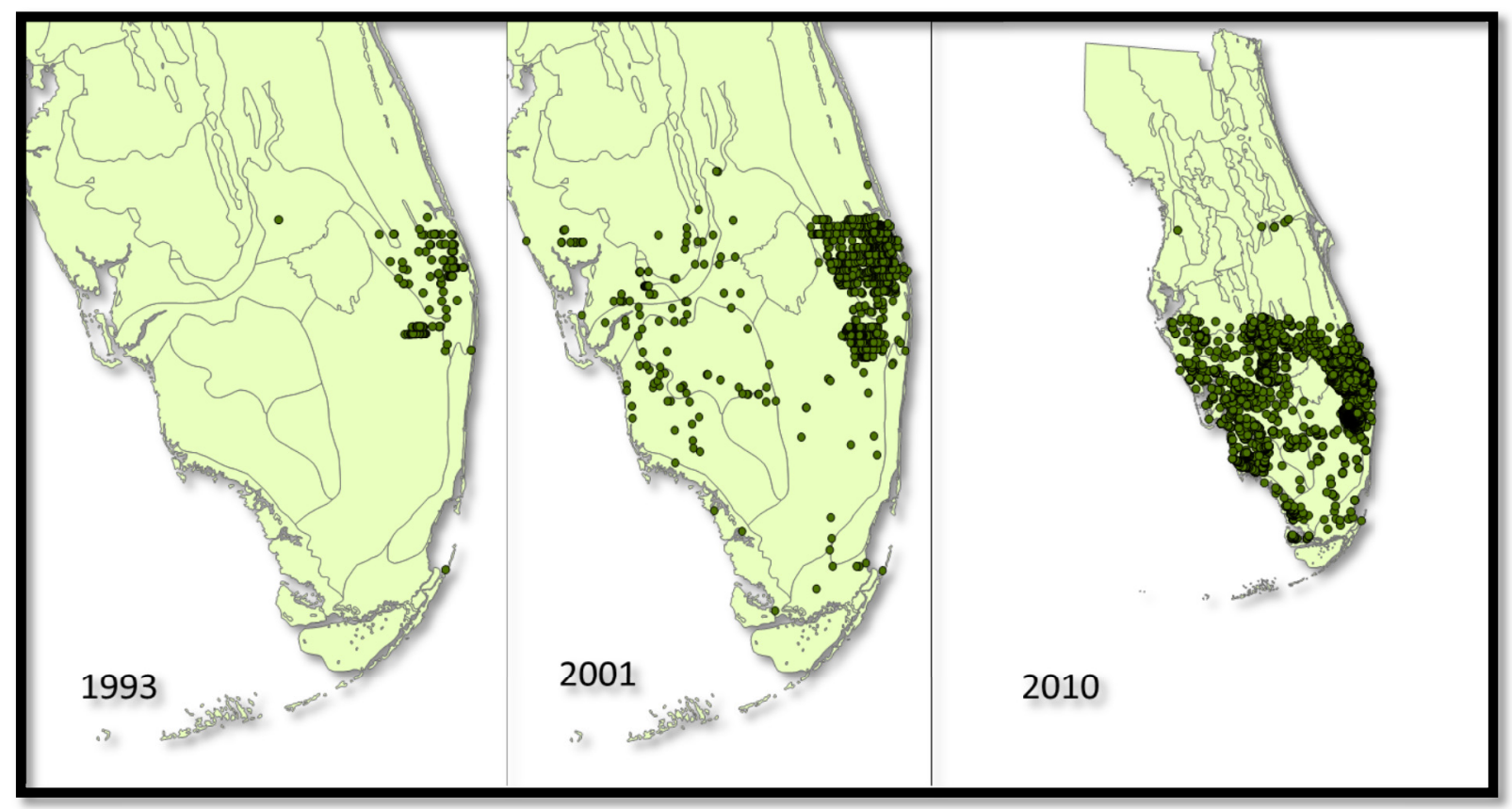

Figure 0.2 Increase in the distribution of Lygodium microphyllum in Florida from 1993 to 2010, data source: Florida Exotic Pest Plant Council (FLEPPC).

\subsection{Dissertation Outline}

My study combined two experimental approaches: i) cross continental field study to compare the growth environment faced by L. microphyllum in its native range in Australia and the recipient community in Florida; ii) growth rate experiment conducted in a greenhouse and a growth chamber to examine phenotypic plasticity and growth response of L. microphyllum with various soil treatments. The dissertation is organized in six chapters. The first chapter provides a basic introduction to the problem and focus of the study. Chapter 2, 3, 4 and 5 are independent chapters addressing the interaction of $L$. microphyllum with soil chemical, biological and physical parameters. Finally, chapter 6 presents the major findings of the dissertation presented in the previous four chapters. 
Additionally it includes the conclusion of the study, directions for future research, and recommendations towards a development of an integrated management technique to control L. microphyllum in the invaded regions of Florida.

In chapter two, analysis of field root and soil samples from the ferns introduced and native range as well as a seven-week growth chamber experiment were done to determine the level of mycorrhizal colonization in the roots of L. microphyllum and the dependency on mycorrhizal fungi for growth and phosphorus $(\mathrm{P})$ uptake. The field root samples showed that L. microphyllum was heavily colonized by arbuscular mycorrhizal fungi (AMF) in relatively dry conditions, which are commonly found in some Florida sites compared to more common wet sites where the fern is found in its native Australia. The results from the growth chamber experiment showed that the mycorrhizal treatment plants had significantly higher relative growth rate and biomass compared to the nonmycorrhizal plants. Similarly, L. microphyllum was highly dependent on the mycorrhizal fungi for growth and $\mathrm{P}$ uptake. Chapter two highlights the role of AMF in the vegetative reproduction and enhanced invasive success of L. microphyllum in south Florida natural areas.

Chapter three investigates the effects of soil $\mathrm{pH}$ on the growth, nutrient uptake and degree of mycorrhizal colonization of L. microphyllum. I conducted a 60 day greenhouse experiment by growing this plant in pots filled with $\mathrm{pH}$ adjusted soils to a range of 4.8 to 8.0. Lygodium microphyllum was able to survive and grow at all soil $\mathrm{pH}$ levels; however, final biomass, relative growth rate, photosynthesis, and specific leaf area were all significantly greater in soil $\mathrm{pH} 5.5$ - 6.5 compared to the other treatments. Correspondingly, leaf nitrogen concentration was also had a significant influence on 
these four plant parameters. Root colonization by mycorrhizal fungi was significantly higher in soil $\mathrm{pH}$ 5.5-7.5 than in lower or higher $\mathrm{pH}$ soil, and was significantly correlated with plant growth parameters as well as elemental concentration in the leaves. In its native Australia, L. microphyllum responds robustly following fire. Fire is also known to commonly raise soil $\mathrm{pH}$, and given the treatment response to soil $\mathrm{pH}$ in this study and the plant's known fire tolerance in its home range, this management option should likely be reconsidered.

In chapter four, I compared the soil characteristics six invaded and adjacent uninvaded plots in three different locations. The results from this study show that the fern can grow and thrive in a wide range of soil types and the impact on the soil was site specific with effects being more prominent in sites with low nutrient status. Additionally, there was significant difference in the soil nutrient status in the invaded and uninvaded sites. Sites with Old World climbing fern had significantly higher nutrient concentration with the corresponding differences in the soil organic matter. Overall my study highlights that this exotic pest plant can alter its belowground environment to its own benefit by enhancing the soil nutrient status with the added soil organic matter.

In chapter five, I conducted a cross continent comparison of soil characteristics associated with L. microphyllum. Here, I present evidence that the invasion by $L$. microphyllum in south Florida is not only facilitated by the soil microbial community but also by the soil chemical characteristics. My results indicate that aluminum, which is considered phytotoxic in acidic soil condition, was significantly higher in Australian soils compared to the Florida soils. I suggest that invasive plants not only escape from their natural herbivores but also the toxic soil environment in their native habitats and 
conclude that a successful management technique and the future invasion prediction model should consider the soil elemental status.

Finally in chapter six, the major findings of the dissertation presented in the previous four chapters are presented. Along with discussion on the conclusions, recommendations are presented for the development of a successful integrated management technique for L. microphyllum in Florida and the restoration of the previously invaded habitats.

\section{References}

Bowen, G.D. and A.D. Rovira. 1999. The rhizosphere and its management to improve plant growth. Adv. Agron. 66:1-102.

Coleman, D.C., E.P. Odum, and D.A. Crossley, Jr. 1992. Soil biology, soil ecology and global change. Biol. Fert. Soils 14:104-111.

Craighead, F.C. Sr. 1971. The Trees of South Florida, Vol. I: The Natural Environments and Their Succession, University of Miami Press, Coral Gables, Fla.

Davis, S.M., and Ogden J.C, 1994. Everglades: The ecosystem and restoration. St. Lucie Press, Delray Beach, FL, USA. p. 36-58.

Davis, J.H., Jr. 1943. The natural features of southern Florida, especially the vegetation of southern Florida. Q.J. Fla Acad. Sci., 25:1-28.

Helal, H.M., and D.R. Sauerbeck. 1989. Carbon turnover in the rhizosphere. Zeitschrift für flanzenernahrung und Bodenkunde 152: 211-216.

Langeland, K. A., \& Hutchinson, J. (2013). Natural area weeds: Old world climbing fern (Lygodium microphyllum).

Lynch, J.M. 1990. The Rhizosphere. Wiley-Interscience Publication. John Wiley \& Sons Ltd., Chichester, England. 
Olmstead, I. C., Loope L. L., and Rintz, R. E. 1980. A Survey and Baseline Analysis of Aspect of the Vegetation of Taylor Slough, Everglades National Park, Report T586, South Florida Research Center, National Park Service, U.S. Department of the Interior, Homestead, Fla.

Olmstead, I.C., Loope L. L., and Hilsenbeck C. E. 1981. Tropical Hardwood Hammocks of the Interior of Everglades National Park and Big Cypress National Preserve, Report T-604, South Florida Research Center, National Park Service, U.S. Department of the Interior, Homestead, Fla.

Reddy, K. R., Angelo, E.M.D. and Harris, W.G. 1999. Biogeochemistry of wetlands, In M.E. Sumner (ed.), Handbook of Soil Sciences. CRC, Boca Raton. p 89-119.

Reich, P.B., S.E. Hobbie, T. Lee, D.S. Ellsworth, J.B. West, D. Tilman, J.M.H. Knops, S. Naeem, and J.Trost. 2006. Nitrogen limitation constrains sustainability of ecosystem response to $\mathrm{CO}_{2}$. Nature 440:922-925.

Steward, K.K., and Ornes, W.H. 1983. Mineral nutrition of sawgrass (Cladium jamaicense Crantz) in relation to nutrient supply. Aquat. Bot, 16: 349-359.

Van Veen, J.A., E. Liljeroth, L.J.A. Lekkerkerk, and S.C. Van de Geijn. 1991. Carbon fluxes in plant soil systems at elevated atmospheric $\mathrm{CO}_{2}$. Ecol. Appl. 1:175-181.

Xu, Z., and C. Chen. 2006. Fingerprinting global climate change and forest management within rhizosphere carbon and nutrient cycling processes. Environ. Sci. Pollut. Res. 13: 293-298.

Zak, D.R., D.B. Ringelberg, K.S. Pregitzer, D.L. Randlett, D.C. White, and P.S. Curtis. 1996. Elevated atmospheric $\mathrm{CO}_{2}$ and feedback between carbon and nitrogen cycles. Plant Soil 151: 105-117. 


\section{MYCORRHIZAL SYMBIOSIS AND LYGODIUM MICROPHYLLUM INVASION IN SOUTH FLORIDA - A BIOGEOGRAPHIC COMPARISON}

Soti PG, Jayachandran K, Purcell M, Volin JC, and Kitajima K , (2013) Mycorrhizal Symbiosis and Lygodium microphyllum Invasion in South Florida- a Biogeographic Comparison. (In Review) Symbiosis.

Abstract

Lygodium microphyllum (Old World climbing fern) is one of the most problematic weeds in south Florida, invading numerous habitats from mangroves to pine flatwoods natural ecosystems. Much of the research efforts on L. microphyllum has been focused on reproductive potential, spore release, growth under different environmental conditions, belowground rhizome dormancy and survival strategies that describes its invasiveness. However, the role of an important mutualistic association with arbuscular mycorrhizal fungi (AMF) in the competitive ability and successful invasion of $L$. microphyllum by enhancing nutrient uptake has not been previously considered. Analysis of field root and soil samples from the ferns introduced and native range as well as a seven-week growth chamber experiment were done to determine the level of mycorrhizal colonization in the roots of L. microphyllum and the dependency on mycorrhizal fungi for growth and phosphorus $(\mathrm{P})$ uptake. The field root samples showed that L. microphyllum was heavily colonized by AMF in relatively dry conditions, which are commonly found on some Florida sites compared to wet sites where the fern is found in its native Australia. The results from the growth chamber experiment showed that the mycorrhizal treatment plants had significantly higher relative growth rate and biomass compared to the non-mycorrhizal plants. Similarly, L. microphyllum was highly dependent on the 
mycorrhizal fungi for growth and $\mathrm{P}$ uptake. My results suggest that AMF play a significant role in vegetative reproduction and likely enhance the invasiveness of $L$. microphyllum in south Florida natural areas.

Key words: arbuscular mycorrhizal fungi (AMF), inorganic phosphorus, relative growth rate (RGR), mycorrhizal dependency, exotic pest plant.

\subsection{Introduction}

Lygodium microphyllum (Old World Climbing Fern) is one of the most problematic weeds in south Florida. It invades many freshwater and moist habitats and is common in cypress swamp, pine flatlands, wet prairies, sawgrass marshes, mangrove communities, and the Everglades tree islands (Pemberton and Ferriter, 1998). L. microphyllum, with its ability to form dense mats, spreads very rapidly and dominates both understory and overstory native wetland habitats. It has the ability to grow in varying hydrological (Gandiaga et al. 2009), nutrient (Volin et al. 2010) and light gradients (Volin et al. 2004). It is estimated to occupy 183,080 acres across the South/Central Florida region (Ferriter and Pernas 2006) and a model developed by Volin et al. (2004) shows that, in the absence of aggressive control measures, L. microphyllum's infestations could exceed the current combined coverage of the top five most invasive species in Florida by 2014. Managing L. microphyllum has been a significant challenge for land resource managers and researchers because of its extensive rapid invasion in natural areas of south Florida. Much of the research work previously performed on $L$. microphyllum focuses on reproductive potential, spore release, belowground rhizome 
dormancy and survival strategies investigating its invasiveness (Lott et al. 2003). Volin et al. (2010) have suggested that the belowground microbial community can influence the establishment of L. microphyllum in south Florida and contribute to its invasiveness. Thus the role of belowground biota in invasions by exotic plants cannot be overlooked, in particular, the role of arbuscular mycorrhizal fungi (AMF) deserves consideration.

Most vascular plants form symbiotic associations with AMF, and many plants are highly dependent on this association for their growth and survival (Smith and Read 1997). Arbuscular mycorrhizal fungi are obligate symbionts of plants; approximately 95\% of all vascular plants can form AMF associations (Fitter and Moyersoen 1996). Read (1991) stated that the mycorrhizal association is the most ubiquitous and abundant form of terrestrial symbiosis, and AMF are considered the most common type of mycorrhizae which dominates grasslands, croplands, tropical forests, and desert communities. They occur naturally in most soils and their important ecosystem function is to assist in the acquisition of soil mineral nutrients (Dighton 2003). Arbuscular mycorrhizal fungi are known to benefit plants by improving plant phosphorus $(\mathrm{P})$ uptake (Fitter, 1990; Gao et al. 2007) and also potentially enhance defense against soil born pathogens (Azcón-Aguilar and Barea 1997). South Florida soils are poor in P because of the binding of $\mathrm{P}$ with $\mathrm{Ca}$ in alkaline soils and to certain extent $\mathrm{Al}$ or $\mathrm{Fe}$ in acidic soils. Arbuscular mycorrhizal fungi can facilitate P uptake by increasing 1) diffusion rate into plant roots; 2) $\mathrm{P}$ concentration at the root surface; and 3) the rate of $\mathrm{P}$ dissociation from the surface of soil particles (Bolan 1991). Elements other than P, such as N, Cu and Zn, also experience enhanced uptake through AMF (Gildon and Tinker 1983; Gao et al. 2007). It has been estimated that external hyphae of AMF can contribute up to $80 \%$ of the 
P, $10 \%$ of the N, $10 \%$ of the K, $25 \%$ of the $\mathrm{Zn}$, and $60 \%$ of the $\mathrm{Cu}$ absorbed by plants ( $\mathrm{Li}$ et al. 1991; Marschner and Dell 1994; DeLuca et al. 2002). Mycorrhizal fungi help overcome the nutrient deficiency by extending their external hyphae to areas of soil beyond the depletion zone and increasing the absorptive surface of the root. However, Smith and Read (1997) have reported that host plant species do not equally benefit from AMF and some plants acquire more nutrients from AMF than others. Furthermore if the symbiotic relationship is non-host specific competing plant species could be interconnected by AMF hyphal networks (Grime et al. 1987; Newman 1988) thus creating an imbalance in the nutrient distribution in the soil. This imbalance in nutrient distribution could interfere the competitive interaction between native and exotic species by promoting growth of the invasive species and inhibiting growth of the native plant species (Fumanal et al. 2006; Callaway et al. 2008).

Populations of AMF are highly influenced by the various environmental factors including climatic conditions, soil physico-chemical properties, age of the host plant species etc. In southeastern Queensland, Australia, the native range of L. microphyllum is climatically similar to the L. microphyllum invaded areas of south Florida (Volin et al. 2010) however the soil physico-chemical properties are significantly different in these two locations. Thus in my study, I characterized the root colonization by AMF in $L$. microphyllum under field conditions in both its native Australia and its introduced environment in Florida. I further explored the influence of AMF on the growth and biomass allocation strategy of $L$. microphyllum in growth chambers. The objectives of this study were to: 1) evaluate the mycorrhizal status of natural populations of $L$. microphyllum in both Australia and Florida; 2) determine the effect of AMF on the 
reproductive and biomass allocation strategy of L. microphyllum; and, 3) evaluate the dependency of L. microphyllum on AMF for growth and phosphorus uptake. Ihypothesized that the south Florida population of L. microphyllum would have a higher degree of mycorrhizal colonization compared to the Australian population because of the difference in soil characteristics. I also hypothesized that L. microphyllum is highly dependent on AMF for increased biomass accumulation and P uptake.

\subsection{Methods}

\subsubsection{Experiment 1: Degree of mycorrhizal colonization in L. microphyllum}

Roots and rhizosphere soil samples (for nutrient analysis and spore extraction) of wild L. microphyllum were collected from different locations in south Florida and Australia to assess the mycorrhizal fungal root colonization and presence of AMF spores. To estimate the AMF colonization, root samples were collected from fully grown adult plants from populations that were known to be at least five years old in both Australia and south Florida. The locations, sampling date and the dominant vegetation in each of the sites are given in Table 1 . Root tip samples were placed in $70 \%$ ethanol immediately until further processing following the method described in McGonigle et al. (1990). At least $10 \mathrm{~cm}$ of fine roots from multiple plants were collected at seven different locations. These roots were cut into $1.5 \mathrm{~cm}$ fragments, cleared in $15 \% \mathrm{KOH}$ at $70^{\circ} \mathrm{C}$ for 4 hours, rinsed twice with water, bleached with ammoniated $\mathrm{H}_{2} \mathrm{O}_{2}$, and acidified with $1 \mathrm{~N} \mathrm{HCl}$. Once the roots were cleared, staining was done using 0.05\% Trypan blue in acidic glycerol at $80^{\circ} \mathrm{C}$ for 20 minutes. The stained roots were examined with a dissecting microscope at 30-60 X magnification; the portions that showed the presence of 
mycorrhizal fungi were mounted on slides in lactic acid and further examined at 100-400 $\mathrm{X}$ magnification to analyze the presence of mycorrhizal structures (hyphae, vesicles, and arbuscules). At least 50 root fragments were selected randomly for each site and the percentage of colonization was estimated.

The wet sieving and decanting technique was used to enumerate the mycorrhizal spores in the soil (Gerdemann et al. 1963). The soil samples were mixed to homogeneity. Fifty grams of the soil sample were then mixed with water and passed through a series of sieves allowing heavy soil particles to settle for a few seconds. The sievate retained on the sieves was washed and centrifuged with water to remove floating organic debris and the supernatant was discarded. The pellet in the bottom was re-suspended in a $50 \%$ sucrose solution, and centrifuged for one minute at 2000 RPM to separate the spores from denser soil components. Immediately after centrifugation, spores in the sucrose supernatant were rinsed in a fine sieve to remove the sucrose. The spores were then washed into a filter paper for vacuum filtration. The spores on the filter paper were counted under a stereo microscope.

\section{Analysis of soil properties}

At each sampling site, six $1 \mathrm{~m}$ x $1 \mathrm{~m}$ plots were selected randomly and soil sample was collected from the $10-15 \mathrm{~cm}$ deep zone at all four corners and the center of each plot with a soil corer (core diameter: $18 \mathrm{~mm}$ ) and mixed homogeneously into one bulk sample for each plot. The samples were collected to a depth of 10-15 cm. The soil samples from south Florida were transported to the laboratory in a cooler; the Australian samples were stored at $4^{\circ} \mathrm{C}$ and were shipped overnight. The soil samples for the 
chemical and physical properties were air dried and passed through a $2 \mathrm{~mm}$ sieve. They were then ground to fine powder with a mortar and pestle, and stored at room temperature in air-tight containers for further analysis of nutrients. The soil $\mathrm{pH}$ was measured with a $\mathrm{pH}$ meter, (soil solution ratio 1:1 in water), texture was measured by the hydrometer method, percentage of carbon and nitrogen was measured with a TruSpec Carbon/Nitrogen Analyzer (Leco Corporation, USA), total organic matter was measured based on the standard loss on ignition method $\left(500^{\circ} \mathrm{C}, 5\right.$ hours; Storer 1984), for the measurement of total $\mathrm{P}$, soil samples $\left(0.25\right.$ grams, finely ground) were ashed $\left(500^{\circ} \mathrm{C}\right)$, digested in $2 \mathrm{ml} \mathrm{HCL}(6 \mathrm{~N})$ and $10 \mathrm{ml} \mathrm{HNO}_{3}$, and then analyzed with an UV spectrophotometer (Shimadzu Scientific Instruments, ) (total P and some other variables were not measured for samples collected in 2006).

\subsubsection{Experiment 2: Mycorrhizal dependency of L. microphyllum}

\section{Plant Material}

Experimental plants were grown from spores collected from an infestation in Jonathan Dickinson State Park, Florida, following the method used by Lott et al. (2003). The spores of L. microphyllum were disinfected with $1 \%$ bleach and transferred to Petri dishes that contained Parker-Thomson Medium. The plates were placed in an incubator set at $25-27^{\circ} \mathrm{C}$ for ten weeks and were watered with sterile DI water every week. After ten weeks, individual gametophytes were transferred to fresh Petri dishes. When the sporelings' roots and leaves developed, 50 plants were transplanted to small pots previously filled with sterile sand. These 50 plants were placed in a growth chamber for approximately four weeks. The plants were kept very moist, and were watered with half 
strength Hoagland's nutrient solution as needed. Plants were then transferred to $2.5 \mathrm{~L}$ pots filled with the top soil collected from a L. microphyllum infested site located in the Tree Tops County Park, Davie, Florida. The potting soil was sterilized in an autoclave to kill mycorrhizal fungal spores to ensure the experimental plants remained free of mycorrhizal fungi.

\section{Growth Chamber Experiment}

A seven-week growth chamber (Percival Scientific, with irradiance $=500 \mu \mathrm{mol}$ $\mathrm{m}^{-2} \mathrm{~s}^{-1}$, photoperiod $=12 \mathrm{~h}$ and temperature $27^{\circ} \mathrm{C}$ ) experiment was done to determine the mycorrhizal dependency of L. microphyllum. The experiment consisted of two treatments: mycorrhizal treatment and non-mycorrhizal treatment with eight replicate pots per treatment. In the mycorrhizal treatment plants received mycorrhizal inoculum; the top soil collected from the field directly under L. microphyllum while a systemic fungicide was added every three weeks in the non-mycorrhizal treatment plants to prevent any kind of mycorrhizal contamination during the experiment. The nonmycorrhizal plants received $50 \mathrm{ml}$ of microbial wash to provide similar microflora except the mycorrhizal fungi. The microbial wash was prepared by filtering the field soil slurry through a $25 \mu \mathrm{m}$ filter paper, which removed the mycorrhizal fungi spores in the soil but allowed the other soil microorganisms to pass through (Johnson 1993). Three hundred $\mathrm{mg}$ of the systemic fungicide Benomyl was applied in $100 \mathrm{ml}$ of water per pot $(50 \mathrm{mg} / \mathrm{kg}$ growth medium); this fungicide is reported to effectively reduce the mycorrhizal colonization in roots without significant impact on the plants (Fitter and Nichols 1988; Hetrick et al. 1992). Plants were watered to saturation once per week and received $250 \mathrm{ml}$ 
of half strength Hoagland's solution weekly, modified by the addition of phosphorus as inositol hexaphosphate (Marler et al. 1999). This form of phosphorus is not directly available to plants for uptake, and requires alteration in the soil by mycorrhizal fungi, soil microbes, or root exudates (DeLucia et al. 1997).

\section{Measurements}

Two harvests were conducted during this study: at time 0 (the transplanting day), and after 50 days. The allometric relationship between stem length and total mass $\left(\mathrm{R}^{2}=\right.$ 0.87 ) from the time 0 harvest was developed to estimate the initial plant mass of the experimental plants and to calculate the relative growth rate (RGR) (see Gandiaga et al. 2009). The RGR ( $\mathrm{mg} \mathrm{g}^{-1} \mathrm{~d}^{-1}$ ) was calculated for individual plants used for the experiment, where $\mathrm{RGR}=[\ln ($ final dry mass)-ln (initial dry mass) $] /$ days (Evans, 1972). After each harvest, roots, stem, and leaves (pinnae) were separated from each plant and the leaf area was measured with the leaf area meter to calculate the specific leaf area (SLA). The separated plant parts were oven-dried $\left(\right.$ at $70^{\circ} \mathrm{C}$ ) to constant mass and weighed to determine the leaf mass ratio (LMR), stem mass ratio (SMR), rhizome mass ratio (RhiMR), and root mass ratio (RMR); differences in the mean growth parameters between the treatments and relative growth rate (RGR). The roots were washed with water. Twenty $1-\mathrm{cm}$ root pieces were collected from each plant before drying to quantify the AMF colonization in the roots. Root and shoot dry mass were measured after ovendrying for one week at $65^{\circ} \mathrm{C}$. Leaf samples $(0.25$ grams, finely ground) were ashed $\left(500^{\circ} \mathrm{C}\right)$, digested in $2 \mathrm{ml} \mathrm{HCL}(6 \mathrm{~N})$ and $10 \mathrm{ml} \mathrm{HNO}_{3}$, and then analyzed with an $\mathrm{UV}$ spectrophotometer (Shimadzu Scientific Instruments, US) for total phosphorus (P) 
concentration. The percentage of carbon and nitrogen in the leaves was measured with a TruSpec Carbon/Nitrogen Analyzer (Leco Corporation, US) and the $\mathrm{C} / \mathrm{N}$ ratio was calculated. Dependency of shoot P uptake and growth of plants on AMF was calculated using the formulae from Plenchette et al. (1989), where $+\mathrm{M}$ represents inoculated plants and $-\mathrm{M}$, fungicide treated plants:

Dependency of P uptake $=\frac{\mathrm{P} \text { content }(+\mathrm{M})-\mathrm{P} \text { content }(-\mathrm{M})}{\mathrm{Pcontent}(+\mathrm{M})} \times 100$

Dependency of growth $=\frac{\text { Total dry mass }(+M)-\text { Total dry mass }(-M)}{\text { Total dry mass }(+M)} \times 100$ 


\subsubsection{Statistical Analyses}

Data for the soil and mycorrhizal colonization (Experiment 1) were analyzed with one-way analysis of variance (ANOVA) to compare the means of the $\mathrm{pH}$, total $\mathrm{P}$, total $\mathrm{N}$ and soil organic matter from different sites. Correlation analysis determined the association of soil $\mathrm{pH}$ and organic matter on the degree of mycorrhizal colonization.

For the green house experiment (Experiment 2), after the harvest at 50 days, regression analysis examined the influence of initial plant mass on RGR and its morphological, allocational and physiological determinants as it has been reported frequently (e.g., Mcconnaughay and Coleman 1999; Volin et al. 2002; Kruger \& Volin 2006). Regression analysis indicated that RGR was negatively correlated to initial plant mass $(\mathrm{p}<0.001)$. Additionally, RhMR and SLA at final harvest were all significantly related $(\mathrm{P}<0.05)$ to final plant mass. Therefore, each was normalized for variation in plant mass using analysis of covariance. All of the variables in mycorrhizal and nonmycorrhizal treatments were then compared with two-treatment t- test for significance at $\mathrm{p} \leq 0.05$. Regression analysis was also used to assess relationships between RGR and its principal determinants. All the parameters were analyzed with SAS Version 9.2 software.

\subsection{Results}

\subsubsection{Degree of mycorrhizal colonization and influence of soil factors}

A wide variety of different fungal structures such as extraradical hyphae, vesicles, and arbuscules were visible in root samples from all sites. The total percentage of roots colonized by arbuscular mycorrhizal fungi in the south Florida plants in some cases were up to three times that of the Australian plants (Table 1.1). In Florida, the range was from 
$31-79 \%$, while in Australia the range was much narrower, 27-29\%. Mycorrhizal spores were present in the rhizosphere soil samples from all sites; spore abundance was highest in Tree Tops Park in south Florida, while the lowest abundance of spores at Nudgee in Australia.

Tree Tops Park, the south Florida site had slightly higher total $\mathrm{P}$ in the soil but this difference was not significantly different (Fig. 1.1a). However there was a significant difference in the total $\mathrm{C}$ and $\mathrm{N}$ among the different sites (Fig. 1.1 a, b). Tree Tops Park in Florida and Logan in Australia had significantly higher percentage of C and N compared to the other sites. The south Florida soil samples were slightly acidic, ranging from 5.49 at Tree Tops Park to 6.22 at Jonathan Dickinson Park. However, the Australian soil samples were highly acidic ranging from 3.97 at Nudgee to 4.7 at Logan. Soil organic matter was significantly higher in the Tree Tops and Logan than at Jonathan Dickinson, Nudgee and Daintree (Table 2.1). 

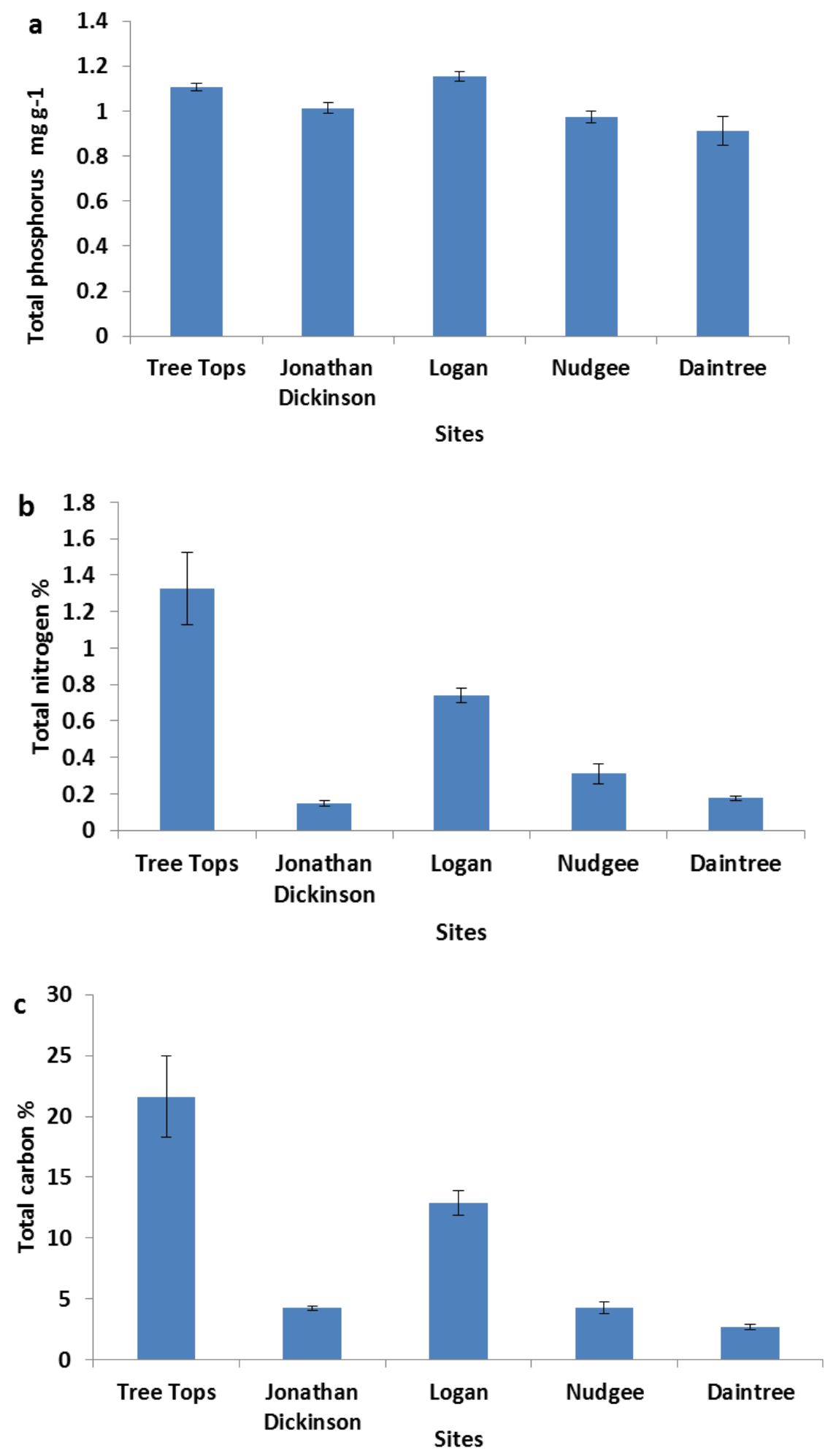

Figure 0.1 Means ( \pm SE) of soil nutrients: a) total soil phosphorus (mg g-1); b) total soil nitrogen $\%$; c) total soil carbon (\%). 

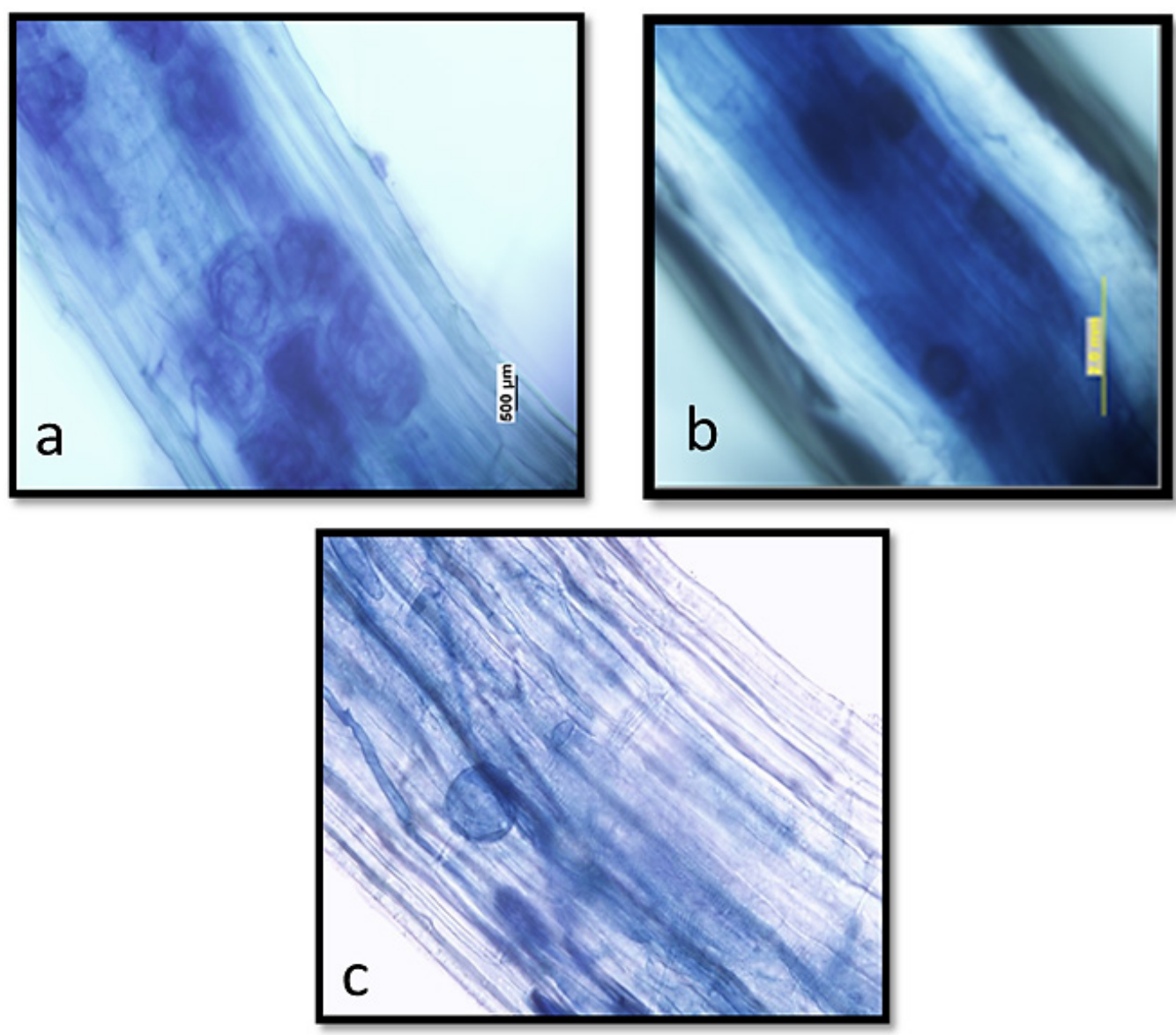

Figure 0.2 Arbuscular mycorrhizal fungal structures (a), vesicles and fungal hyphae (b), in root cortex region of South Florida Plants, vesicles and fungal hyphae in the root cortex region of Australian plants (c). 
Table 0.1 Sampling site information with the number of AMF spores and mycorrhizal colonization.

\begin{tabular}{|c|c|c|c|c|c|c|c|c|}
\hline Site & Coordinates & $\begin{array}{l}\text { Dominant } \\
\text { vegetation }\end{array}$ & $\begin{array}{c}\text { Soil } \\
\text { texture }\end{array}$ & $\mathrm{pH}$ & SOM \% & $\begin{array}{c}\text { No. of } \\
\text { spores/10g dry } \\
\text { soil }\end{array}$ & $\begin{array}{l}\text { Sampling } \\
\text { Date }\end{array}$ & $\begin{array}{l}\text { Deg. of colonization } \\
(\%)[\min -\max ]\end{array}$ \\
\hline Tree Tops Park, FL, US & $\begin{array}{c}26^{\circ} 4^{\prime} 0.04^{\prime \prime} \mathrm{N} \\
80^{\circ} 16^{\prime} 5.88^{\prime \prime} \mathrm{W}\end{array}$ & Royal fern & $\begin{array}{l}\text { Sandy } \\
\text { loam }\end{array}$ & 5.56 & $39.7 \pm 1.6$ & $29 \pm 7$ & Dec, 2010 & $\begin{array}{l}79 \pm 3.0 \\
{[65-85]}\end{array}$ \\
\hline $\begin{array}{c}\text { Jonathan Dickinson, FL, } \\
\text { US }\end{array}$ & $\begin{array}{l}27^{\circ} 0{ }^{\prime} 37.33^{\prime \prime} \mathrm{N} \\
80^{\circ} 7^{\prime} 20.28^{\prime \prime} \mathrm{W}\end{array}$ & Slush pine & Sand & 6.02 & $4.30 \pm 0.9$ & $19 \pm 5$ & Dec, 2010 & $\begin{array}{c}74 \pm 2.2 \\
{[67-88]}\end{array}$ \\
\hline $\begin{array}{c}\text { Big Cypress Seminole } \\
\text { Indian Reservation, FL, } \\
\text { US }\end{array}$ & $\begin{array}{l}\text { Approximately, } \\
26^{\circ} 17^{\prime} \mathrm{N} \\
80^{\circ} 54^{\prime} \mathrm{W}\end{array}$ & $\begin{array}{l}\text { Bald } \\
\text { cypress }\end{array}$ & Sand & 4.99 & $*$ & $*$ & $\begin{array}{l}\text { October, } \\
2006\end{array}$ & $\begin{array}{c}31 \pm 7.8 \\
{[16.0-49.5]}\end{array}$ \\
\hline $\begin{array}{l}\text { Daintree Ferry, } \\
\text { Queensland, AU }\end{array}$ & $\begin{array}{l}16^{\circ} 15^{\prime} 25.57^{\prime \prime S} \\
145^{\circ} 24^{\prime} 3.94^{\prime \prime} \mathrm{E}\end{array}$ & Drynaria & Silt loam & 4.43 & $8.07 \pm 1.2$ & $12 \pm 6$ & June, 2011 & $\begin{array}{c}27 \pm 1.4 \\
{[24-33]}\end{array}$ \\
\hline $\begin{array}{l}\text { Logan Reserve, } \\
\text { Queensland, AU }\end{array}$ & $\begin{array}{l}27^{\circ} 40^{\prime} 4.16^{\prime \prime} \mathrm{S} \\
153^{\circ} 16^{\prime} 0.44^{\prime \prime} \mathrm{E}\end{array}$ & $\begin{array}{l}\text { Bungwall } \\
\text { fern }\end{array}$ & $\begin{array}{l}\text { Sandy } \\
\text { clay loam }\end{array}$ & 4.55 & $35.5 \pm 2.9$ & $15 \pm 3$ & June, 2011 & $\begin{array}{c}28 \pm 1.3 \\
{[25-32]}\end{array}$ \\
\hline Nudgee, Queensland, AU & $\begin{array}{l}27^{\circ} 22^{\prime} 31.12^{\prime \prime S} \\
153^{\circ} 5^{\prime} 39.42^{\prime \prime} \mathrm{E}\end{array}$ & Melaleuca & Loam & 4.01 & $11.45 \pm 1.9$ & $10 \pm 5$ & June, 2011 & $\begin{array}{l}27 \pm 0.6 \\
{[25-29]}\end{array}$ \\
\hline $\begin{array}{c}\text { SE Brisbane, Queensland, } \\
\text { AU }\end{array}$ & $\begin{array}{l}27^{\circ} 40.36^{\prime} \mathrm{S} \\
153^{\circ} 16.60^{\prime} \mathrm{E}\end{array}$ & Melaleuca & $\begin{array}{l}\text { Sandy } \\
\text { loam }\end{array}$ & 5.55 & 6.83 & $*$ & $\begin{array}{l}\text { February, } \\
2006\end{array}$ & $\begin{array}{l}24.0 \pm 2.7(3) \\
{[19.5-28.9]}\end{array}$ \\
\hline $\begin{array}{l}\text { Near Amity Point, } \\
\text { Stradbroke Island, } \\
\text { Queensland, AU. }\end{array}$ & $\begin{array}{l}\text { Approximately, } \\
27.4^{\circ} \mathrm{S}, 153.4^{\circ} \mathrm{E}\end{array}$ & Melaleuca & Sand & * & $*$ & $*$ & $\begin{array}{l}\text { February, } \\
2006\end{array}$ & $\begin{array}{c}30.2 \pm 6.5(5) \\
{[7.4-44.7]}\end{array}$ \\
\hline
\end{tabular}

Note: Mean values \pm standard error, Soil organic matter $(\mathrm{SOM})$, number of samples $(\mathrm{N})$, * values not determined. 
Correlation analysis shows that the degree of colonization was signifi positively correlated with soil $\mathrm{pH}(\mathrm{r}=0.86, \mathrm{p}<0.001) ; \mathrm{N} \%(\mathrm{r}=0.45, \mathrm{p}=0.026)$; and ( $=0.43, \mathrm{p}=0.0177)$ while there was no significant correlation with soil organic me $=0.02, \mathrm{p}=0.35)$.

\subsubsection{Mycorrhizal dependency}

As expected, in the non-mycorrhizal treatment, benomyl application signifi suppressed the mycorrhizal colonization of L. microphyllum roots. After 50 days colonization rate was high in the mycorrhizal treatment $(>75 \%)$, but low $(<5 \%)$ non-mycorrhizal treatment (Fig. 2.2). Different fungal structures were observed i: plant roots including hyphae, vesicles as well as arbuscules.
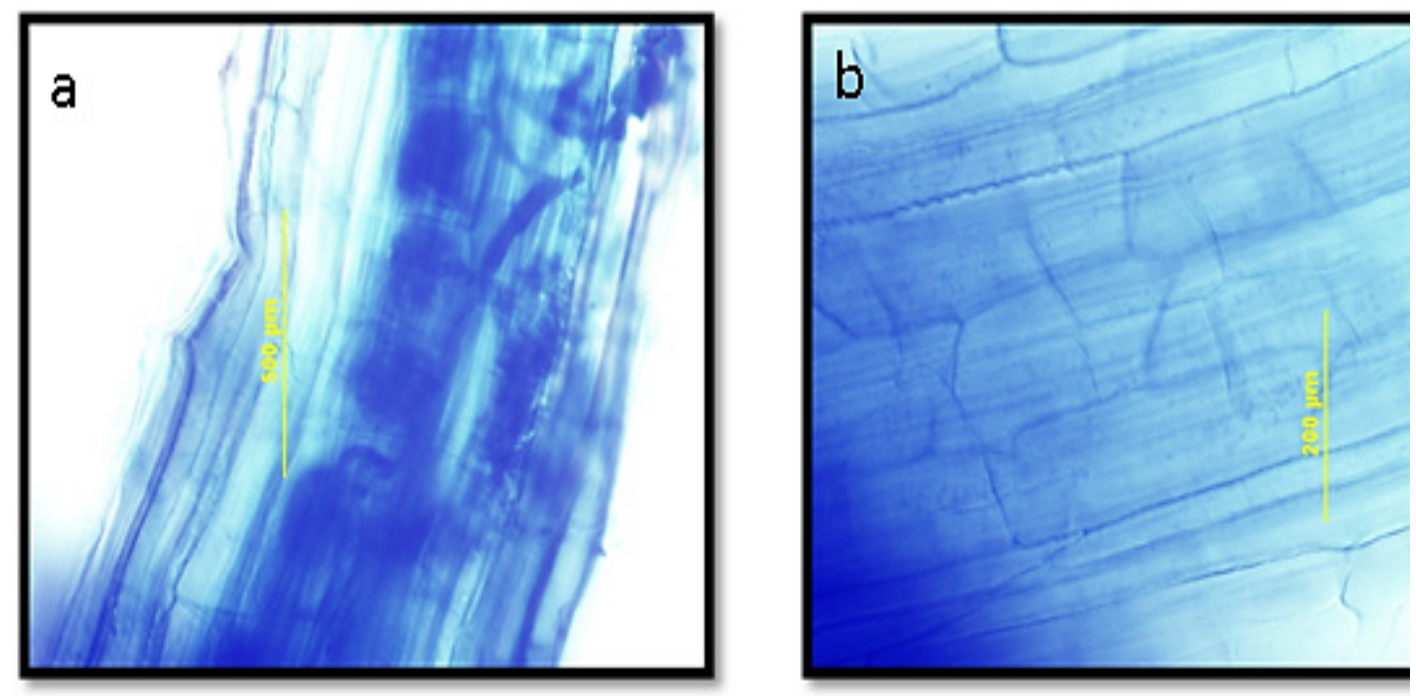

Figure 2.3 High colonization of the roots by arbuscular mycorrhizal fungi in the mycorrhizal treatment plants (a), no colonization in the non-mycorrhzial treatment $\mathrm{r}$ (b), at the end of 50 days. 
The mycorrhizal plants had greater total P uptake in shoots compared to the nonmycorrhizal plants. The mycorrhizal dependency index for growth was $67 \%$, and $64 \%$ for $\mathrm{P}$ uptake. Relative growth rate of mycorrhizal treated plants was $29 \%$ greater $(\mathrm{P}=0.01)$ than the RGR of the non-mycorrhizal plants (Table 2). Correspondingly, the mean biomass of the L. microphyllum plants inoculated with mycorrhizal fungi was also significantly greater (by 66\%) $(\mathrm{P}=0.001)$ than the non-mycorrhizal plants (Table 2).

There was no significant difference in SMR $(\mathrm{P}=0.15)$ or LMR $(\mathrm{P}=0.99)$ between the two treatments (Table 2.2). On the other hand, allocation to rhizomes (RhiMR) $(\mathrm{P}=0.001)$ was significantly different between treatments, resulting in greater rhizome allocation for mycorrhizal plants compared to untreated plants. In contrast, mycorrhizal plants tended to allocate less to roots than non-mycorrhizal plants $(\mathrm{P}=0.08)$.

The mycorrhizal treatment increased the leaf area of the plants nearly four-fold $(\mathrm{P}=0.0001)$ and SLA was significantly greater $(\mathrm{P}=0.003)(24 \%)$ in the presence of mycorrhizal fungi compared to non-mycorrhizal plants. There was no significant difference $(\mathrm{P}=0.83)$ in the average $\mathrm{P}$ concentration in the leaves of the mycorrhizal and non-mycorrhizal plants. However, the total P per plant $(3,291 \mu \mathrm{g})$ of the mycorrhizal plants was significantly higher $(\mathrm{P}=0.0001)$ than the non-mycorrhizal plants. 
Table 0.2 Effect of arbuscular mycorrhizal fungi (AMF) inoculation on plant growth parameters and on leaf content of biolimiting elements ( $\mathrm{P}$ and $\mathrm{N})$.

\begin{tabular}{lccc}
\hline Variable & Mycorrhizal & Non-mycorrhizal & P value \\
\hline Final biomass $(\mathrm{g})$ & $1.99 \pm 0.37$ & $0.68 \pm 0.17$ & 0.0001 \\
RGR mg g ${ }^{-1} \mathrm{day}^{-1}$ & $75.13 \pm 0.01$ & $53.88 \pm 0.01$ & 0.000 \\
SMR & $0.17 \pm 0.03$ & $0.20 \pm 0.05$ & 0.15 \\
RMR & $0.18 \pm 0.05$ & $0.24 \pm 0.08$ & 0.08 \\
RhiMR & $0.24 \pm 0.04$ & $0.14 \pm 0.04$ & 0.001 \\
LMR & $0.42 \pm 0.02$ & $0.42 \pm 0.02$ & 0.99 \\
SLA & $505 \pm 64$ & $383.6 \pm 85$ & 0.003 \\
Leaf area $\left(\mathrm{cm}^{2}\right)$ & $414 \pm 112$ & $109.7 \pm 40.7$ & 0.0001 \\
Total P per plant $(\mu \mathrm{g})$ & $3,291 \pm 615$ & $1,129 \pm 279$ & 0.0001 \\
C/N ratio & $1.7 \pm 0.1$ & $1.6 \pm 0.1$ & 0.21 \\
\end{tabular}

Note: mean values ( $\pm \mathrm{SD}$ ) of the study variables: relative growth rate $(\mathrm{RGR})$, stem mass ratio (SMR), root mass ratio ( $R M R$ ), rhizome mass ratio (RhiMR), leaf mass ratio (LMR), specific leaf area (SLA) after growing 7 weeks in a growth chamber: analyzed by (two sample t test, $\mathrm{p}<0.05$ ).

\subsection{Discussion and Conclusion}

The results of this study suggest that L. micorphyllum likely has a strong symbiotic relationship with mycorrhizal fungi, and the degree of mycorrhizal colonization is generally higher in the invaded regions of south Florida than in the plant's native range in Australia. Detailed information on the mycorrhizal status of the coexisting species is not available but the high degree of mycorrhizal colonization may assist in 
absorption and competition for nutrients in the fern's introduced environment, especially on sandy sites with low water holding capacity. This could in turn provide a competitive advantage over native Florida plants. However, others have found that that many invasive plants do not associate with mycorrhizal fungi (see Pringle et al. 2009). Plants such as Alliaria petiolata, Centaurea diffusa, etc. have been found to use alternative mechanisms to disrupt existing symbiotic relationships by secreting lethal biochemicals in the introduced range, resulting in the reduced growth and competitiveness of native plants (Callway and Aschehoug 2000; Callaway et al. 2008).

My results show that soil $\mathrm{pH}$ is positively correlated with mycorrhizal colonization, indicating that the low soil $\mathrm{pH}$ of the Australian soil may influence the degree of mycorrhizal colonization and the number of spores associated with $L$. microphyllum, other research have shown species-specific responses of AMF to soil $\mathrm{pH}$ (Wang et al. 1985; Porter et al. 1987; Gemma et al. 1989). It is widely reported that abundance of mycorrhizal fungi declines in response to $\mathrm{N}$ and $\mathrm{P}$ fertilization (see Treseder 2004). In contrast, My results indicate a positive correlation between mycorrhizal colonization and soil nitrogen. Similar results have also been reported by (Persson \& Ahlstrom 1991; Heijne et al. 1992). I did not determine the mycorrhizal fungal species in my study but there is substantial variation in the environmental effects on different mycorrhizal fungal species, this variation could explain in part the contradictory results seen in my study. Likewise, there was a significantly positive correlation between the root mycorrhizal status and soil $\mathrm{C} \%$, this result supports the existing assumption that mycorrhizal fungi have a significant contribution to soil carbon storage (Treseder and Allen 2000). 
Interestingly, the two sites in Florida with high AMF colonization appear to be drier than the four Australian sites and one Florida Big Cypress Seminole Indian Reservation site. These latter sites are characterized by periodic inundation that may or may not occur on an annual basis, while the two dry Florida sites are not inundated for any appreciable amount of time. Relationship between flooding and AMF colonization seen in my study could explain in part the lowered growth rate of L. microphyllum in flooded conditions compared to the drought and field conditions seen by Gandiaga et al. (2009). Additionally, Rickerl et al. (1994); Stevens and Peterson (1996); and Miller (2000) have found a strong relationship between mychorrizal colonization and site hydrology, and this potential relationship for L. microphyllum needs to be explored further.

We found that L. microphyllum can attain high RGR under suitable environmental conditions. A high RGR for invasive species has been reported for many different species (Burns 2004; James and Drenovsky 2007; Soti and Volin 2010). From an ecological perspective, high RGR can lead to the rapid occupation of a large space, which could be advantageous for exotic invasive plants (Grime and Hunt 1975). In my study, RGR in $L$. microphyllum was highly enhanced by the presence of mycorrhizal fungi. Mycorrhizal plants produced almost three times more biomass than non-mycorrhizal plants. Increased growth and development in mycorrhizal plants compared to non-mycorrhizal plants has also been found in several different species (Gupta and Janardhanan 1991; Smith and Read 1997; Guadarrama et al. 2004; Liu et al. 2005; Pezzani et al. 2006). On the other hand, Philip et al. (2001) observed that colonization by AMF of Lythrum salicaria decreased plant biomass both aboveground and belowground. Likewise Botham et al. 
(2009) observed that the AMF inoculated Fragaria virginiana plants showed no difference in biomass accumulation and growth rate compared to control plants.

The mycorrhizal treatment plants had significantly higher SLA compared to the non-mycorrhizal plants. The difference in the SLA between the two treatments could lead to higher RGR in the mycorrhizal plants. Although we did not measure photosynthesis in our study, Gandiaga et al. (2009) found that SLA together with photosynthesis were the major determinants of growth in L. microphyllum plants grown under different hydrological conditions. Other studies, using different species, have also found that mycorrhizal plants had higher leaf area, leaf area ratio and SLA compared with control plants (Waschkies et al. 1994; Caglar and Bayram, 2006; Vega-Frutis et al. 2011).

The enhanced ability of a plant to take up phosphorus from low $\mathrm{P}$ soils is considered to be the major contributing factor for mycorrhizal dependency (Hall 1975; Smith \& Read 1997). Increased P uptake by the extraradical mycelia of mycorrhizal fungi in the roots may allow L. microphyllum to absorb more nutrients leading to larger shoots and more extensive roots, compared to non-mycorrhizal plants. This relationship would potentially convey a competitive growth advantage in the fern's introduced range in Florida as this region is conspicuous for its P-limiting growth environment (McCormic et al. 1999). Previous research has shown that AMF increase plant uptake of phosphate (Bolan 1991), micronutrients (Burkert and Robson 1994), nitrogen (Barea et al. 1991), and act as antagonists against some plant pathogens (Duponnois et al. 2005). Moreover, it has been demonstrated that plants inoculated with AMF utilize more soluble phosphate from rock phosphate than non-inoculated plants (Antunes and Cardoso 1991). The 
current study supports these results since the mean P uptake per plant was significantly greater in the mycorrhizal plants than in the non-mycorrhizal plants.

In conclusion, it is clear that L. microphyllum can form a very strong symbiotic relationship with AMF in its introduced environment in Florida. It is likely that this relationship is strongly influenced by site hydrological conditions, but this hypothesis will need to be tested in future research, especially when the Florida Everglades is undergoing a major hydrological shift as an effort for restoration. The enhanced mycorrhizal fungi are also likely responsible for the greater $\mathrm{P}$ uptake and biomass accumulation in the control study. Symbiotic relationships such as found in my study, are highly beneficial, and likely enhance the aggressive growth characteristic of this exotic pest plant in its de novo environment. Further field experiments are necessary to better evaluate the potential role of mycorrhizal fungi in the growth of this highly invasive species in south Florida natural areas.

\section{Acknowledgements}

This research was supported by the Dissertation Evidence Acquisition Fellowship, to Pushpa Soti from the Graduate School, Florida International University. Helpful comments on the manuscript were made by, Suzanne Koptur, Michael Sukop and Florentin Maurrasse. 


\section{References}

Antunes V, E Cardoso 1991 Growth and nutrient status of citrus plants as influenced by mycorrhiza and phosphorus application. Plant Soil ;131:11-19.

Azcón-Aguilar, C., \& Barea, J. M. (1997). Arbuscular mycorrhizas and biological control of soil-borne plant pathogens-an overview of the mechanisms involved. Mycorrhiza; $6: 457-464$.

Barea, J.M., 1991 Vesicular-arbuscular mycorrhizae as modifier of soil fertility. Adv. Soil Sci. 15, 1-40.

Bolan N 1991 A critical-review on the role of mycorrhizal fungi in the uptake of phosphorus by plants. Plant Soil ;134:189-207.

Botham R, CL Collin, T Ashman 2009 Plant-mycorrhizal fungus interactions affect the expression of inbreeding depression in wild strawberry. Int.J.Plant Sci. ;170:143-150.

Burkert B, A Robson 1994 Zn-65 uptake in subterranean clover (Trifolium-Subterraneum L) by 3 vesicular-arbuscular mycorrhizal fungi in a Root-Free Sandy Soil. Soil Biology \& Biochemistry; 26:1117-1124.

Burns J 2004 A comparison of invasive and non-invasive dayflowers (Commelinaceae) across experimental nutrient and water gradients. Divers. Distrib.; 10:387-397.

Caglar S, A Bayram 2006 Effects of vesicular-arbuscular mycorrhizal (VAM) fungi on the leaf nutritional status of four grapevine rootstocks. European Journal of Horticultural Science ;71:109-113.

Callaway RM, D Cipollini, K Barto, GC Thelen, SG Hallett, D Prati, K Stinson, J Klironomos 2008 Novel weapons: invasive plant suppresses fungal mutualists in America but not in its native Europe. Ecology; 89:1043-1055.

Callaway R, E Aschehoug 2000 Invasive plants versus their new and old neighbors: A mechanism for exotic invasion. Science; 290:521-523.

DeLucia E H, R. M. Callaway, E. M. Thomas, and W. H. Schlesinger. 1997 Mechanisms of $\mathrm{P}$ acquisition for pon- derosa pine under different climatic regimes. Annals of Botany 79:111-120.

DeLuca T, O Zackrisson, M Nilsson, A Sellstedt 2002 Quantifying nitrogen-fixation in feather moss carpets of boreal forests. Nature; 419:917-920.

Dighton, J. 2003. Fungi in ecosystem processes. New York, NY. Marcel Dekker, Inc. 
Duponnois R, A Colombet, V Hien, J Thioulouse 2005 The mycorrhizal fungus Glomus intraradices and rock phosphate amendment influence plant growth and microbial activity in the rhizosphere of Acacia holosericea. Soil Biology \& Biochemistry;37:14601468.

Evans GC 1972 The Quantitative Analysis of Plant Growth. Blackwell Scientific Publications, Oxford.

Fitter A 1990 The role and ecological significance of vesicular-arbuscular mycorrhizas in temperate ecosystems. Agriculture Ecosystems \& Environment; 29:137-151.

Fitter A, B Moyersoen 1996 Evolutionary trends in root-microbe symbioses.

Philosophical Transactions of the Royal Society of London Series B-Biological Sciences ;351:1367-1375.

Ferriter A and T Pernas 2006 An explosion in slow motion: tracking the spread of Lygodium microphyllum in Florida. Wildland Weeds 9, 7-9.

Fumanal B, C Plenchette, B Chauvel, F Bretagnolle 2006 Which role can arbuscular mycorrhizal fungi play in the facilitation of Ambrosia artemisiifolia L. invasion in France? Mycorrhiza ;17:25-35.

Gandiaga S, JC Volin, EL Kruger, K Kitajima 2009 Effects of hydrology on the growth and physiology of an invasive exotic, Lygodium microphyllum (Old World climbing fern). Weed Res. ;49:283-290.

Gao, X., Kuyper, T. W., Zou, C., Zhang, F., \& Hoffland, E. 2007 Mycorrhizal responsiveness of aerobic rice genotypes is negatively correlated with their zinc uptake when nonmycorrhizal. Plant and soil; 290:283-291.

Gemma JN, Koske RE, Carreiro M (1989) Seasonal dynamics of selected species of VAmycorrhizal fungi in a sand dune. Mycol Res 92:317-321

Gerdemann, J.W. and T.H. Nicolson, 1963. Spores of mycorrhizal Endogone species extracted from soil by wet-sieving and decanting. Trans. Br. Mycol. Soc., 46: 235-244

Gildon A, P Tinker 1983 Interactions of vesicular arbuscular mycorrhizal infections and heavy-metals in plants 2. the effects of infection on uptake of copper. New Phytol.; 95:263-268.

Grime JP and R Hunt 1975. Relative growth-rate: its range and adaptive significance in a local flora. J Ecol 63:393-422

Grime, J.P., Mackey, J.M.L., Hillier, S.H. \& Read, D.J. 1987 Floristic diversity in a model system using experimental microcosms. Nature, 328, 420-422. 
Guadarrama P, J Alvarez-Sanchez, A Estrada-Torres 2004 Phosphorus dependence in seedlings of a tropical pioneer tree: The role of arbuscular mycorrhizae. J.Plant Nutr; 27:2159-2174.

Hall I. R. 1975 Endomycorrhizas of Metrosideros umbellate and Weinmannia racemosa. New Zealand Journal of Botany, 13.463-72

Hetrick B, G Wilson, T Todd 1992 Relationships of mycorrhizal symbiosis, rooting strategy, and phenology among tallgrass prairie forbs. Canadian Journal of Botany-Revue Canadienne De Botanique ;70:1521-1528.

Heijne B, Hofstra JJ, Heil GW, Van Dam D, Bobbink R. 1992. Effect of the air pollution component an-imonium sulphate on the VAM infection of three heathland species. Plant and Soil;144: 1-12.

James JJ, RE Drenovsky 2007 A basis for relative growth rate differences between native and invasive forb seedlings. Rangeland Ecology \& Management ;60:395-400.

Johnson N 1993 Can Fertilization of Soil Select Less Mutualistic Mycorrhizae. Ecol.Appl. ;3:749-757.

Kruger, E.L. and J.C. Volin. 2006. Reexamining the empirical relation between plant growth and leaf photosynthesis. Functional Plant Biology ;33:421-429.

Li X, E George, H Marschner 1991 Extension of the phosphorus depletion zone in vamycorrhizal white clover in a Calcareous Soil. Plant Soil ;136:41-48.

Liu, Y., Y. G. Zhu, B. D. Chen, P. Christie, and X. L. Li. 2005 Influence of the arbuscular mycorrhizal fungus Glomus mosseae on uptake of arsenate by the As hyperaccumulator fern Pteris vittata L. Mycorrhiza ;3: 187-192.

Lott, MS, JC Volin, RW Pemberton and DF Austin. 2003. The reproductive biology of Lygodiummicrophyllum and L. japonicum (Schizaeaceae) and its implications for invasive potential. American Journal of Botany; 90:1144-1152.

Marler M, C Zabinski, R Callaway 1999 Mycorrhizae indirectly enhance competitive effects of an invasive forb on a native bunchgrass. Ecology ;80:1180-1186.

Marschner H, B Dell 1994 Nutrient-Uptake in Mycorrhizal Symbiosis. Plant Soil ;159:89-102.

McCormic P, Newman, S Miao, R Reddy, D Gawlik, C. Fitz, T. Fontaine, and D. Marley 1999 Ecological needs of the Everglades. Chapter 3 in G. Redfield, editor. Everglades Interim Report. South Florida Water Management District, West Palm Beach, FL. 
McConnaughay K, J Coleman 1999 Biomass allocation in plants: Ontogeny or optimality? A test along three resource gradients. Ecology ;80:2581-2593.

McGonigle TP, Miller MH, Evans DG, Fairchild GL, Swan JA. 1990. A new method which gives an objective measure of colonization of roots by vesicular-arbuscular mycorrhizal fungi. New Phytologist ;115: 495-501.

Miller S, R Sharitz 2000 Manipulation of flooding and arbuscular mycorrhiza formation influences growth and nutrition of two semiaquatic grass species. Funct. Ecol.; 14:738748.

Newman, E.I. (1988) Mycorrhizal links between plants: their functioning and ecological significance. Advances in Ecological Research ;18: 243-270.

Persson H, Ahlstrom K. 1991. The effect of forest liming on fine-root growth. Water Air Soil Pollution 54: 365-375

Pemberton R, A Ferriter 1998 Old World climbing fern (Lygodium microphyllum), a dangerous invasive weed in Florida. Am.Fern J. ;88:165-175.

Pezzani F, C Montana, R Guevara 2006 Associations between arbuscular mycorrhizal fungi and grasses in the successional context of a two-phase mosaic in the Chihuahuan Desert. Mycorrhiza ;16:285-295.

Philip L, U Posluszny, J Klironomos 2001 The influence of mycorrhizal colonization on the vegetative growth and sexual reproductive potential of Lythrum salicaria L. Canadian Journal of Botany-Revue Canadienne De Botanique; 79:381-388.

Porter W, A Robson, L Abbott 1987 Field Survey of the Distribution of Vesicular Arbuscular Mycorrhizal Fungi in Relation to Soil-Ph. J. Appl. Ecol.; 24:659-662.

Pringle A, JD Bever, M Gardes, JL Parrent, MC Rillig, JN Klironomos 2009 Mycorrhizal symbioses and plant invasions. Annual Review of Ecology Evolution and Systematics; 40:699-715.

Read D 1991 Mycorrhizas in Ecosystems. Experientia; 47:376-391.

Rickerl D, F Sancho, S Ananth 1994 Vesicular-Arbuscular Endomycorrhizal Colonization of Wetland Plants. J.Environ.Qual.; 23:913-916.

Rillig, M C, Wright, S. F., Nichols, K. A., Schmidt, W. F., \& Torn, M. S. 2001 Large contribution of arbuscular mycorrhizal fungi to soil carbon pools in tropical forest soils. Plant and Soil, 233(2): 167-177. 
Soti PG, JC Volin 2010 Does water hyacinth (Eichhornia crassipes) compensate for simulated defoliation? Implications for effective biocontrol. Biological Control; 54:3540 .

Stevens K, R Peterson 1996 The effect of a water gradient on the vesicular-arbuscular mycorrhizal status of Lythrum salicaria L (purple loosestrife). Mycorrhiza; 6:99-104.

Storer D 1984 A simple high sample volume ashing procedure for determination of soil organic-matter. Commun.Soil Sci.Plant Anal.; 15:759-772.

Treseder, KK, \& Allen, M. F. 2000 Mycorrhizal fungi have a potential role in soil carbon storage under elevated $\mathrm{CO}_{2}$ and nitrogen deposition. New Phytologist, 147(1): 189-200.

Treseder, K K. 2004 A meta-analysis of mycorrhizal responses to nitrogen, phosphorus, and atmospheric $\mathrm{CO}_{2}$ in field studies. New Phytologist, 164(2): 347-355.

Volin J, M Lott, J Muss, D Owen 2004 Predicting rapid invasion of the Florida Everglades by old world climbing fern (Lygodium microphyllum). Divers.Distrib.; 10:439-446.

Volin JC, EL Kruger, VC Volin, MF Tobin, K Kitajima 2010 Does release from natural belowground enemies help explain the invasiveness of Lygodium microphyllum? A crosscontinental comparison. Plant Ecol.; 208:223-234.

Waschkies C, A Schropp, H Marschner 1994 Relations between grapevine replant disease and root colonization of grapevine (Vitis $\mathrm{sp}$ ) by fluorescent pseudomonads and endomycorrhizal fungi. Plant Soil; 162:219-227. 


\title{
EFFECT OF SOIL pH ON GROWTH, NUTRIENT UPTAKE, AND MYCORRHIZAL COLONIZATION IN EXOTIC INVASIVE LYGODIUM MICROPHYLLUM
}

Soti Pushpa G., K Jayachandran, S Koptur, and JC Volin (2013) Effect of soil pH on growth, nutrient uptake, and mycorrhizal colonization in exotic invasive Lygodium microphyllum (In Review) Biological Invasions.

\begin{abstract}
Lygodium microphyllum is an invasive exotic plant species taking over many sites in freshwater and moist habitats in Florida. Managing it has been a significant challenge for land resource managers and researchers because of its extensive rapid invasion. To assess the effects of soil $\mathrm{pH}$ on growth, nutrient uptake and mycorrhizal colonization in the roots of L. microphyllum, we conducted a 60-day greenhouse experiment by growing the fern in pots filled with $\mathrm{pH}$ adjusted soils to a range from 4.5 to 8.0. Lygodium microphyllum was able to survive and grow at all soil $\mathrm{pH}$ levels; however, final biomass, relative growth rate, photosynthesis and specific leaf area were all significantly greater in soil $\mathrm{pH} 5.5$ - 6.5 compared to other treatments. Correspondingly, nitrogen concentration was also significantly related to these four plant parameters. Root colonization by mycorrhizal fungi was significantly higher in soil $\mathrm{pH}$ 5.5-7.5 and lowest for plants growing in 4.5 or 8.0 , and was significantly correlated with plant growth parameters as well as elemental concentration in the leaves. In its native Australia, L. microphyllum responds robustly following fire. Fire increases soil $\mathrm{pH}$, and given the treatment response to soil $\mathrm{pH}$ in my study, increased $\mathrm{pH}$ may help partially explain L. microphyllum's response to burning. Recently, fire has been used as a potential management control option in its introduced range in Florida, given the results of this study and the plants
\end{abstract}


known fire tolerance in its home range, this management option should be reconsidered.

Key words: element toxicity, invasive species management, plant-soil interactions, relative growth rate.

\subsection{Introduction}

Soil $\mathrm{pH}$ is an important factor for plant growth, as it affects nutrient availability, nutrient toxicity, and has a direct effect on the protoplasm of plant root cells (Rorison 1980; Alam et al. 1999). It also affects the abundance and activity of the soil organisms (from microorganisms to arthropods) responsible for the transformations of nutrients (De Boer and Kowalchuk, 2001; Nicol et al. 2008). Since most mineral nutrients are readily available to plants when soil $\mathrm{pH}$ is near neutral $(\mathrm{pH}=7.0)$, species richness is high in such neutral soils, declining in both acidic and alkaline soils (Grime 1973; Gould and Walker 1999; Pausas and Austin 2001). Soil pH further influences the fate of chemicals, nutrients, and pesticides/herbicides added to the soil (Liu et al. 2001). Past research has shown that the species diversity is low in most acidic soils (Dupre et al. 2002) as essential nutrients (such as calcium, magnesium, potassium, phosphorus, and molybdenum) exist in unavailable forms to plants causing nutrient deficiency (Larcher 1980). Likewise, because to the inhibition of nitrification processes, nitrite, which can be toxic to plant and microorganisms, accumulates in acidic soils (Black 1968; Shen et al. 2003). In strongly acidic soils, certain ions $\left(\mathrm{Al}^{3+}, \mathrm{Cu}^{2+}, \mathrm{Fe}^{3+}, \mathrm{Mn}^{2+}\right)$ rise to levels toxic for the majority of plants (Foy 1984; Kinraide 1993). Additionally, acidic soils have high cation exchange capacity, and promote leaching of nutrients resulting in soil unfavorable for plant growth (Johnson 2002). At the other extreme, alkaline soils tend to be deficient in iron, 
manganese and phosphate (Marschner 1986; Tyler 1999). Marschner (1986) suggest that in alkaline soils, boron can rise to phytotoxic concentrations.

Plants differ enormously in their degree of tolerance to changes in soil characteristics $(\mathrm{pH}$, moisture content, etc.): some have a narrow tolerance for one variable but a wide tolerance for others (Hill \& Ramsay 1977). Weedy species collected from different climate zones show large growth differences when planted in soils with $\mathrm{pH}$ ranging from 4.8 to 6.4 (Buchanan et al.1975). Stephenson \& Rechcigl (1991) found that many weedy species grew significantly better when soil $\mathrm{pH}$ increased from 4.5 to 5.4 , with good growth maintained at $\mathrm{pH}$ of 5.5 and above. Since invasive species have an affinity for disturbed areas, can reproduce sexually as well as asexually and yield a high number of seeds, they have a greater ability to adapt to changing conditions, potentially displacing native species through competitive exclusion (Baker 1974; Mooney and Cleland 2001; Prentis et al. 2008).

Lygodium microphyllum is an invasive exotic plant species taking over many sites in freshwater and moist habitats in Florida. It has the ability to grow in varying hydrological (Gandiaga et al. 2009), nutrient (Volin et al. 2010), and light conditions (Volin et al. 2004). Analysis of soil samples from both its native range and invaded region have shown that although $L$. microphyllum grows in highly acidic soils in its native range in Australia, it has adapted to thriving in close-to-neutral soils in Florida (Chapter 2). The roots of L. microphyllum are heavily colonized by mycorrhizal fungi that absorb nutrients, specifically P; biomass accumulation in mycorrhizal plants was almost three times that of non-mycorrhizal plants (Chapter 2). Furthermore, the level of mycorrhizal colonization was related with the soil $\mathrm{pH}$ : a higher degree of mycorrhizal 
colonization is present in plants from the slightly acidic soils in the invaded regions compared with those from the highly acidic soil in the native regions (Chapter 2). Since mycorrhizal fungi have strong associations with L. microphyllum, supporting nutrient uptake in both its invaded regions as well as in the native regions (Chapter 2), the response of mycorrhizal fungi to variation in soil $\mathrm{pH}$ should be considered, especially if the manipulation of soil $\mathrm{pH}$ is integrated in the management plan for this invasive pest plant.

The aim of this study was to compare the degree of mycorrhizal colonization, nutrient uptake, biomass accumulation, and growth rate of L. microphyllum at different soil $\mathrm{pH}$ levels. Since the existing chemical control method is not very efficient in controlling L. microphyllum, this information may be useful in developing an integrated weed management technique. I hypothesized that plant growth and mycorrhizal colonization will be highest in slightly acidic soils with growth highly reduced (or the plants not surviving) in alkaline soils. I predicted that changing the soil $\mathrm{pH}$ can reduce the competitive ability of L. microphyllum. 


\subsection{Methods}

To test the hypothesis, I undertook a greenhouse experiment to investigate the effects of soil $\mathrm{pH}$ on various aspects of growth of L. microphyllum. Plants were maintained in pots in the Florida International University greenhouses until they began to sporulate, at which time the experiment was concluded.

\subsubsection{Potting soil}

Soil from plots in Tree Tops County Park at Davie, Florida was collected for this study; this site was not yet invaded by L. microphyllum. Soil was then passed through a 2 $\mathrm{mm}$ sieve and air dried in room temperature. Quartz sand was added to this soil to form a 1:1 soil/sand ratio. A sub-sample of the soil was analyzed to determine the initial soil characteristics. The soil $\mathrm{pH}$ was measured with a $\mathrm{pH}$ meter, (soil solution ratio 1:2 in water), texture was measured by the hydrometer method, total organic matter was measured on the basis of standard loss on ignition method $\left(500^{\circ} \mathrm{C}, 5\right.$ hours; Storer 1984). To generate a soil neutralization curve (Kellog et al. 1957), $150 \mathrm{~g}$ of air dried soil samples were placed in $120 \mathrm{ml}$ plastic containers and mixed with $\mathrm{Ca}(\mathrm{OH})_{2}$ at rates 0,1 ,

2, 3, 4, 5, 6, 7, $8 \mathrm{Mg} \mathrm{Ha}^{-1}$, elemental $\mathrm{S}$ was added at rates $0.35,0.40,0.450 .50,0.55$ and $0.60 \mathrm{Mg} \mathrm{Ha}^{-1}$, with 5 replicates for each treatment. These soil samples were watered with DI water and incubated for 28 days and the soil $\mathrm{pH}$ was measured (soil solution ratio 1:2 in water). The amount of lime or sulfur required to raise the experimental soil $\mathrm{pH}$ to the desired level was determined based on the regression equation resulting from $\mathrm{pH}$ measurement of the incubated soils. The rate of $\mathrm{Ca}(\mathrm{OH})_{2}$ and $\mathrm{S}$ added is given in Table 3.1 . 
The soil was sandy loam with organic matter $37 \%, 1.10 \mathrm{mg} / \mathrm{g}$ total $\mathrm{P}, 1.2 \%$ total $\mathrm{N}$ and $\mathrm{pH} 5.5 \pm 0.2$. The soil was divided into 5 subsamples and elemental sulfur was added to lower the $\mathrm{pH}$ to 4.5 in one set; no treatment was done in the 5.5 pots; and $\mathrm{Ca}(\mathrm{OH})_{2}$ was added to increase the $\mathrm{pH}$ to $6.5,7.5$ and 8.0. The soil samples with elemental sodium or $\mathrm{Ca}(\mathrm{OH})_{2}$ were thoroughly mixed, added to the pots and watered with DI water. The soils were allowed to equilibrate for eight weeks with frequent mixing. Soil $\mathrm{pH}$ was measured weekly and after eight weeks all the $\mathrm{pH}$ measurements were within \pm 0.3 of the targeted $\mathrm{pH}$ value and remained constant throughout the experiment time (measured every week in 1:2 water).

Table 0.1 Rates of application of $\mathrm{Ca}(\mathrm{OH})_{2}$ and elemental $\mathrm{S}$ for $\mathrm{pH}$ adjustment of the experimental soils

\begin{tabular}{ccc}
\hline Soil original $\mathrm{pH}$ & Final $\mathrm{pH}$ & $\begin{array}{c}\text { Rates of S or } \mathrm{Ca}(\mathrm{OH})_{2} \\
\text { Application }\left(\mathrm{Mg} \mathrm{Ha}^{-1}\right)\end{array}$ \\
\hline 4.5 & 0.522 \\
5.5 & 5.5 & 0.000 \\
& 6.5 & 2.215 \\
& 7.5 & 4.255 \\
& 8.0 & 5.275 \\
\hline
\end{tabular}

\subsubsection{Plant material}

Experimental plants were grown from spores following the method used by Lott et al. (2003). Spores of L. microphyllum were disinfected with $1 \%$ bleach and transferred 
to Petri dishes that contained Parker-Thomson Medium. The plates were placed in an incubator set at $25-27^{\circ} \mathrm{C}$ for ten weeks and were watered with sterile DI water every week. After ten weeks, individual gametophytes were transferred to fresh Petri dishes. When the sporelings' roots and leaves developed, 60 plants were transplanted to small pots previously filled with sterile sand. These 60 plants were placed in a growth chamber for approximately four weeks. The plants were kept moist, and were watered with half strength Hoagland's nutrient solution as needed. Plants were then transferred to $2.5 \mathrm{~L}$ pots filled $\mathrm{pH}$ modified soil. The plants were grown in the green house for 60 days. Plants were watered to saturation biweekly and received $250 \mathrm{ml}$ of half strength Hoagland's solution weekly. Before the plants were harvested, photosynthesis was measured using a Li-Cor 6400 Portable Photosynthesis System (Li-Cor Biosciences) on two fully grown leaves per plant in all the treatments. Measurements were taken at leaf temperatures ranging from $34^{\circ} \mathrm{C}$ to $38^{\circ} \mathrm{C}, \mathrm{CO}_{2}$ concentration of $400 \mu \mathrm{mol} \mathrm{mol}{ }^{-1}$ and photosynthetic photon flux was at $600 \mu \mathrm{mol} \mathrm{m} \mathrm{m}^{-2}$.

\subsubsection{Harvest and plant nutrient analysis}

Two harvests were conducted during this study: at time 0 (the beginning of the treatment/transplant date), and after 60 days. The allometric relationship between stem length and total mass $\left(\mathrm{R}^{2}=0.92\right)$ from the initial harvest was developed to estimate the initial plant mass of the experimental plants and to calculate the relative growth rate (RGR) (see Gandiaga et al. 2009). The RGR (mg g ${ }^{-1} \mathrm{~d}^{-1}$ ) was calculated for each individual plant used for the experiment, where RGR $=[\ln$ (final dry mass)-ln (initial dry mass)]/days (Evans 1972). After each harvest, individual plants' roots, stem, and leaves 
(pinnae) were separated and leaf area was measured with a leaf area meter to calculate the specific leaf area (SLA). The separated plant parts were oven-dried (one week at $65^{\circ} \mathrm{C}$ ) to constant mass and weighed to determine the leaf mass ratio (LMR), stem (rachis) mass ratio (SMR), rhizome mass ratio (RhiMR), and root mass ratio (RMR); and relative growth rate (RGR).

The aboveground parts of the plants (shoot tissue) were analyzed for nutrient content. The oven dried tissues were carefully ground by hand using a mortar and a pestle. Samples underwent acid digestion using Method 3050B (USEPA 1996), summarized here: One gram of finely ground plant tissue sample was transferred to a large glass tube and mixed with $10 \mathrm{ml}$ of $30 \% \mathrm{HNO}_{3}$. The tubes were covered with a vapor recovery system and heated to $95 \pm 5^{\circ} \mathrm{C}$ and refluxed for 10 minutes without boiling under the hood in a heating block maintained with a Partlow Mic 6000 Profile Process Controller. After cooling to $40^{\circ} \mathrm{C}, 5 \mathrm{ml}$ of concentrated $\mathrm{HNO}_{3}$ was added and the sample was heated again until no brown fumes were emitted. After cooling to $40^{\circ} \mathrm{C}, 2 \mathrm{ml}$ of DI water and $3 \mathrm{ml}$ of $30 \% \mathrm{H}_{2} \mathrm{O}_{2}$ was added and heated until the effervescence subsided. The samples were cooled and diluted to $100 \mathrm{ml}$ with DI water, centrifuged at $2000 \mathrm{rpm}$ for 10 minutes and filtered with Whatman No. 41 filter paper and analyzed with an ICP-MS at USDA ARS, Homestead, Florida. 


\subsubsection{Mycorrhizal colonization}

Before drying, forty-five $1.5 \mathrm{~cm}$ root fragments were collected from each plant, and the colonization of AMF was quantified following a modified method described by McGoingle et al. (1990). Roots were cleared in $15 \% \mathrm{KOH}$ at $70^{\circ} \mathrm{C}$ for 4 hours, rinsed twice with water, bleached with ammoniated $\mathrm{H}_{2} \mathrm{O}_{2}$, and acidified with $1 \mathrm{~N} \mathrm{HCl}$. Staining was done using Trypan blue in acidic glycerol at $80^{\circ} \mathrm{C}$ for 20 minutes. The stained roots were examined with a dissecting microscope at 30-60 X magnification; the portions that showed the presence of mycorrhizal fungi were mounted on slides in lactic acid and examined at 100-400 X magnification.

\subsubsection{Experimental design and data analysis}

The experimental design was a randomized complete block with five $\mathrm{pH}$ treatments and six replicates. It was a single factor experiment investigating the effects of $\mathrm{pH}$ on plant growth, nutrient accumulation and level of mycorrhizal colonization. After the harvest at 60 days, regression analysis examined the influence of initial plant mass on RGR and its morphological, allocational and physiological determinants (e.g., Mcconnaughay and Coleman 1999; Volin et al. 2002; Kruger and Volin 2006). Regression analysis indicated that RGR was negatively correlated to the natural $\log (\ln )$ of initial plant mass $(\mathrm{p}<0.001)$. Additionally, RMR final harvest was significantly related $(\mathrm{P}<0.05)$ to final plant mass. Therefore, variation in plant mass was normalized using analysis of covariance. All of the variables in the four $\mathrm{pH}$ treatments were then compared with one-way ANOVA for significance at $\mathrm{p} \leq 0.05$. Correlation analysis between total biomass, RGR SLA, and leaf concentration of $\mathrm{Al}, \mathrm{Ca}, \mathrm{P}, \mathrm{N}$, and Fe were conducted to 
determine the effects of leaf elemental status on plant growth. Regression analysis analyzed the relationship between the plant growth parameters and $\mathrm{N}$ concentration in the leaves. Regression analysis examined the relationship between RGR and its determinants. All analyses were performed with SAS Version 9.2 software (SAS Institute 2009).

\subsection{Results}

A significant effect of soil $\mathrm{pH}$ was visible on L. microphyllum growth, nutrient uptake, and degree of mycorrhizal colonization in its roots, despite the small sample size $(\mathrm{n}=6)$ and short duration (60 days) of this experiment (Fig. 3.1a \& b, Table 3.2, Fig. 3.2). Relative growth rate and biomass allocation patterns were significantly different among the $\mathrm{pH}$ treatments (Fig. 3.1b). The growth of L. microphyllum was significantly greater in pH 5.5 and 6.5 compared to the strongly acidic and alkaline soils (Fig. 3.3). Total final plant mass was greatest in plants grown in soil with $\mathrm{pH} 5.5$ and 6.5 and these were more than twice the biomass of plants grown in $\mathrm{pH} 8.0$ (Fig. 3.1a). Correspondingly, this significant pattern was found for RGR, which increased with increasing soil $\mathrm{pH}$ from 4.5 to 5.5 , remained unchanged at 6.5 , and gradually declined with increasing soil $\mathrm{pH}$, with lowest RGR at soil pH 8.0 (Fig. 3.1b).

Surprisingly, biomass allocation to the above ground parts was not influenced by soil $\mathrm{pH}$ (data not shown). There was, however, significant difference in biomass allocation to the belowground parts. Plants growing in soil $\mathrm{pH} 4.5$ had significantly 

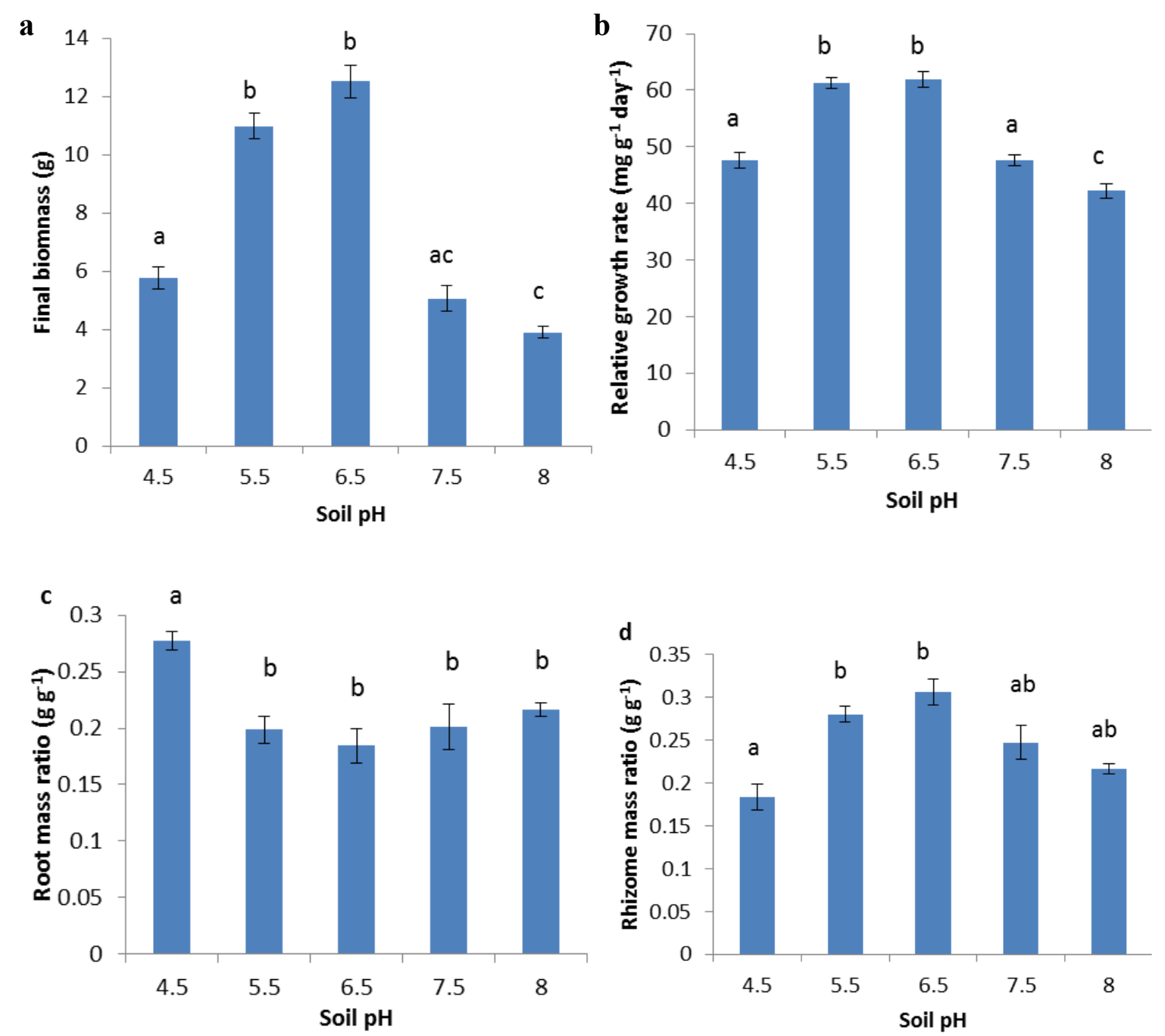

Figure 0.1 Mean $( \pm \mathrm{SE})$ final biomass $(\mathrm{a})$; mean $( \pm \mathrm{SE})$ relative growth rate $(\mathrm{RGR})(\mathrm{b})$; mean $( \pm \mathrm{SE})$ root mass ratio $(\mathrm{RMR})(\mathrm{c})$ and mean $( \pm \mathrm{SE})$ rhizome mass ratio (RhiMR) $(\mathrm{d})$, measured at the end of 60 days in four different soil $\mathrm{pH}$ levels. Similar letters represent no significant difference at $P<0.05$. 
higher biomass allocation to the roots compared to the other plants (Fig. 3.1c), while plants grown in soil $\mathrm{pH} 4.5$ had significantly lower biomass allocation to the rhizomes compared the plants grown in soil pH 5.5 and 6.5 , though not significantly different from $\mathrm{pH} 7.5$ and 8.0. Plants in soil $\mathrm{pH} 5.5$ and 6.5 had significantly higher SLA than the other plants (Fig. 3.3). The influence of soil $\mathrm{pH}$ also was strongly reflected in the photosynthetic rates, which showed the same response as SLA. In other words, plants grown in $\mathrm{pH} 5.5$ and 6.5 had significantly higher area based photosynthetic rates than plants grown in lower or higher $\mathrm{pH}$ soils, but there were no significant differences among the remaining three treatments (Fig. 3.4a). As a result of higher SLA and area based photosynthesis, mass based photosynthesis was also higher in plants grown in $\mathrm{pH} 5.5$ and 6.5 (Fig. 3.4b).

\subsubsection{Element concentration and uptake}

Soil $\mathrm{pH}$ significantly affected the concentrations of $\mathrm{Al}, \mathrm{Ca}, \mathrm{Fe}$, and $\mathrm{N}$ in the leaf tissue of L. microphyllum (Table 3.2), while it did not have any influence on the leaf concentration of $\mathrm{P}, \mathrm{K}, \mathrm{Mg}, \mathrm{Mn}$, and $\mathrm{Zn}$. Plants grown in soil $\mathrm{pH} 4.5$ had significantly higher concentration of $\mathrm{Al}$ and $\mathrm{Fe}$ and significantly lower concentrations of N. Similarly plants grown in $\mathrm{pH} 8.0$ had significantly high concentration of $\mathrm{Ca}$. There was a strong relationship between biomass $(p<0.0001), \quad$ RGR $\quad(p<0.0001)$, SLA $\quad(p<0.0001)$ photosynthesis $(\mathrm{p}<0.0001))$ and RhiMR $(\mathrm{p}<0.0001)$ and leaf concentration of $\mathrm{N}$ when all the treatments were pooled (Fig. 3.5). However, there were no significant correlations between the plant growth parameters and leaf concentration of $\mathrm{Al}, \mathrm{Ca}, \mathrm{Fe}, \mathrm{Mg}, \mathrm{Mn}, \mathrm{P}$, and Zn. 
Table 0.2 Effect of soil $\mathrm{pH}$ on element concentration (mean \pm std. dev.) in the leaf tissue of L. microphyllum

\begin{tabular}{|c|c|c|c|c|c|c|c|c|c|c|}
\hline \multirow{3}{*}{$\begin{array}{l}\text { Element } \\
\mathrm{Al}\end{array}$} & \multicolumn{10}{|c|}{ Concentration $\mathrm{mg} \mathrm{g}^{-1}$} \\
\hline & \multicolumn{2}{|c|}{$\mathrm{pH} 4.5$} & \multicolumn{2}{|c|}{$\mathrm{pH} 5.5$} & \multicolumn{2}{|c|}{ pH 6.5} & \multicolumn{2}{|c|}{$\mathrm{pH} 7.5$} & \multicolumn{2}{|c|}{ pH 8.5} \\
\hline & 0.19 & $\pm 0.02 \mathrm{a}$ & 0.14 & $\pm 0.01 \mathrm{~b}$ & 0.14 & $\pm 0.03 \mathrm{~b}$ & 0.12 & $\pm 0.02 b$ & 0.13 & $\pm 0.02 \mathrm{~b}$ \\
\hline $\mathrm{Ca}$ & 5.44 & $\pm 0.40 \mathrm{a}$ & 5.53 & $\pm 0.33 \mathrm{a}$ & 5.53 & $\pm 0.99 \mathrm{a}$ & 5.52 & $\pm 0.48 \mathrm{a}$ & 7.01 & $\pm 0.5 \mathrm{~b}$ \\
\hline $\mathrm{Fe}$ & 0.18 & $\pm 0.05 \mathrm{a}$ & 0.15 & $\pm 0.03 \mathrm{ab}$ & 0.12 & $\pm 0.01 \mathrm{~b}$ & 0.13 & $\pm 0.02 \mathrm{~b}$ & 0.13 & $\pm 0.01 \mathrm{~b}$ \\
\hline K & 22.01 & $\pm 2.1 \mathrm{a}$ & 21.75 & $\pm 4.56 \mathrm{a}$ & 21.1 & $\pm 4.9 \mathrm{a}$ & 21.16 & $\pm 4.39 \mathrm{a}$ & 23.9 & $\pm 3.0 \mathrm{a}$ \\
\hline $\mathrm{Mg}$ & 2.05 & $\pm 0.29 \mathrm{a}$ & 2.08 & $\pm 0.45 \mathrm{a}$ & 2.13 & $\pm 0.4 \mathrm{a}$ & 1.98 & $\pm 0.14 \mathrm{a}$ & 2.12 & $\pm 0.29 \mathrm{a}$ \\
\hline $\mathrm{Mn}$ & 0.11 & $\pm 0.01 \mathrm{a}$ & 0.10 & $\pm 0.01 \mathrm{a}$ & 0.09 & $\pm 0.05 \mathrm{a}$ & 0.08 & $\pm 0.01 \mathrm{a}$ & 0.08 & $\pm 0.01 \mathrm{a}$ \\
\hline $\mathrm{P}$ & 3.72 & $\pm 0.30 \mathrm{a}$ & 4.25 & $\pm 0.53 \mathrm{a}$ & 3.73 & $\pm 0.85 \mathrm{a}$ & 3.78 & $\pm 0.54 \mathrm{a}$ & 3.46 & $\pm 0.28 \mathrm{a}$ \\
\hline $\mathrm{N}$ & 1.94 & $\pm 0.32 \mathrm{a}$ & 3.34 & $\pm 0.31 \mathrm{~b}$ & 3.35 & $\pm 0.26 \mathrm{~b}$ & 2.83 & $\pm 0.18 \mathrm{c}$ & 1.99 & $\pm 0.23 \mathrm{a}$ \\
\hline $\mathrm{Zn}$ & 0.09 & $\pm 0.01 \mathrm{a}$ & 0.09 & $\pm 0.01 \mathrm{a}$ & 0.07 & $\pm 0.02 \mathrm{a}$ & 0.07 & $\pm 0.01 \mathrm{a}$ & 0.08 & $\pm 0.02 \mathrm{a}$ \\
\hline
\end{tabular}

Values in a row followed by the same letter are not significantly different at $\mathrm{p} \leq 0.05$. 
Table 0.2 Comparison of the topsoil characteristics (means with standard deviations in parentheses) at the three sites with and without L. microphyllum.

\begin{tabular}{|c|c|c|c|c|c|c|c|c|c|c|c|}
\hline Site & & $\begin{array}{l}\mathrm{Al} \\
(\mathrm{mg} / \mathrm{g})\end{array}$ & $\begin{array}{l}\mathrm{C} \\
(\%)\end{array}$ & $\begin{array}{l}\mathrm{Ca} \\
(\mathrm{mg} / \mathrm{g})\end{array}$ & $\begin{array}{l}\mathrm{N} \\
(\%)\end{array}$ & $\begin{array}{l}P \\
(\mathrm{mg} / \mathrm{g})\end{array}$ & $\begin{array}{l}\mathrm{Zn} \\
(\mu \mathrm{g} / \mathrm{g})\end{array}$ & $\begin{array}{l}\text { OM } \\
(\%)\end{array}$ & $\begin{array}{l}\mathrm{pH} \\
\left(\mathrm{H}_{2} \mathrm{O}\right)\end{array}$ & TBC & TFC \\
\hline \multirow[t]{3}{*}{ Central FL } & Native & $\begin{array}{l}2.62 \\
(0.64)\end{array}$ & $\begin{array}{l}2.18 \\
(0.50)\end{array}$ & $\begin{array}{l}0.68 \\
(0.34)\end{array}$ & $\begin{array}{l}0.04 \\
(0.11)\end{array}$ & $\begin{array}{l}0.67 \\
(0.10)\end{array}$ & $\begin{array}{l}21.46 \\
(9.94)\end{array}$ & $\begin{array}{l}5.18 \\
(0.80)\end{array}$ & $\begin{array}{l}4.95 \\
(0.45)\end{array}$ & $\begin{array}{l}152.5 \\
(16.42)\end{array}$ & $\begin{array}{l}61.16 \\
(9.82)\end{array}$ \\
\hline & Invasive & $\begin{array}{l}5.07 \\
(0.68)\end{array}$ & $\begin{array}{l}4.03 \\
(0.84)\end{array}$ & $\begin{array}{l}0.41 \\
(0.13)\end{array}$ & $\begin{array}{l}0.195 \\
(0.27)\end{array}$ & $\begin{array}{l}1.03 \\
(0.26)\end{array}$ & $\begin{array}{l}15.93 \\
(8.25)\end{array}$ & $\begin{array}{l}8.65 \\
(1.09)\end{array}$ & $\begin{array}{l}5.78 \\
(0.12)\end{array}$ & $\begin{array}{l}138.33 \\
(10.78)\end{array}$ & $\begin{array}{l}88.83 \\
(3.31)\end{array}$ \\
\hline & P Level $^{\mathrm{a}}$ & $* *$ & $* *$ & $*$ & ns & $* *$ & ns & $* *$ & $* *$ & ns & $* *$ \\
\hline \multirow[t]{3}{*}{$\begin{array}{l}\text { Jonathan } \\
\text { Dickinson }\end{array}$} & Native & $\begin{array}{l}0.43 \\
(0.07)\end{array}$ & $\begin{array}{l}3.13 \\
(1.10)\end{array}$ & $\begin{array}{l}1.19 \\
(0.21)\end{array}$ & $\begin{array}{l}0.26 \\
(0.08)\end{array}$ & $\begin{array}{l}1.02 \\
(0.06)\end{array}$ & $\begin{array}{l}7.24 \\
(1.26)\end{array}$ & $\begin{array}{l}1.08 \\
(0.41)\end{array}$ & $\begin{array}{l}6.36 \\
(0.09)\end{array}$ & $\begin{array}{l}57.33 \\
(7.25)\end{array}$ & $\begin{array}{l}33.5 \\
(4.84)\end{array}$ \\
\hline & Invasive & $\begin{array}{l}0.93 \\
(0.30)\end{array}$ & $\begin{array}{l}7.02 \\
(1.88)\end{array}$ & $\begin{array}{l}3.35 \\
(1.77)\end{array}$ & $\begin{array}{l}0.44 \\
(0.12)\end{array}$ & $\begin{array}{l}1.15 \\
(0.09)\end{array}$ & $\begin{array}{l}8.77 \\
(1.86)\end{array}$ & $\begin{array}{l}4.32 \\
(0.90)\end{array}$ & $\begin{array}{l}6.57 \\
(0.1)\end{array}$ & $\begin{array}{l}39 \\
(4.28)\end{array}$ & $\begin{array}{l}46.66 \\
(7.76)\end{array}$ \\
\hline & P Level $^{\mathrm{a}}$ & $*$ & $* *$ & * & $* *$ & $*$ & ns & $* *$ & $*$ & $* *$ & $*$ \\
\hline \multirow[t]{3}{*}{ Tree Tops } & Native & $\begin{array}{l}1.62 \\
(0.14)\end{array}$ & $\begin{array}{l}16.55 \\
(3.02)\end{array}$ & $\begin{array}{l}9.11 \\
(1.15)\end{array}$ & $\begin{array}{l}1.31 \\
(0.40)\end{array}$ & $\begin{array}{l}1.11 \\
(0.04)\end{array}$ & $\begin{array}{l}17.48 \\
(5.17)\end{array}$ & $\begin{array}{l}36.75 \\
(0.10)\end{array}$ & $\begin{array}{l}5.54 \\
(0.04)\end{array}$ & $\begin{array}{l}282.5 \\
(11.07)\end{array}$ & $\begin{array}{l}51.66 \\
(5.68)\end{array}$ \\
\hline & Invasive & $\begin{array}{l}1.88 \\
(0.25)\end{array}$ & $\begin{array}{l}22.43 \\
(4.15)\end{array}$ & $\begin{array}{l}17.21 \\
(6.30)\end{array}$ & $\begin{array}{l}1.27 \\
(0.17)\end{array}$ & $\begin{array}{l}1.22 \\
(0.16)\end{array}$ & $\begin{array}{l}23.21 \\
(4.53)\end{array}$ & $\begin{array}{l}44.42 \\
(2.71)\end{array}$ & $\begin{array}{l}5.60 \\
(0.06)\end{array}$ & $\begin{array}{l}143.66 \\
(13)\end{array}$ & $\begin{array}{l}73.83 \\
(12.27)\end{array}$ \\
\hline & P Level $^{\mathrm{a}}$ & $*$ & $*$ & $*$ & ns & ns & $*$ & $* *$ & ns & $* * *$ & $* *$ \\
\hline
\end{tabular}

${ }^{\mathrm{a}}$ Significance for paired t-test, ns: not significant; Probability levels: $*$ : $\mathrm{P}<0.05 ; * * \mathrm{P}<0.01 ; * * * \mathrm{P}<0.0001$. OM: soil organic matter; TBC: total bacterial count (count $\mathrm{x} 10^{7}$ ); TFC: total fungal count (count $\mathrm{x} 10^{3}$ ). 
Table 0.3 Results of two-way analyses of variance (ANOVA) with degree of freedom (DF), F-value and probability levels for the effects of site, plant type and the interaction of the two on the soil characteristics.

\begin{tabular}{|c|c|c|c|c|c|c|c|c|c|c|c|c|c|c|}
\hline Source & DF & $\mathrm{Al}$ & $\mathrm{C}$ & $\mathrm{Ca}$ & $\mathrm{Cu}$ & $\mathrm{Fe}$ & $\mathrm{K}$ & $\mathrm{Mg}$ & $\mathrm{Mn}$ & $\mathrm{N}$ & $\mathrm{P}$ & OM & $\mathrm{Zn}$ & $\mathrm{pH}$ \\
\hline Site & 2 & $\begin{array}{c}195.3 \\
* * *\end{array}$ & $\begin{array}{c}179.89 \\
* * *\end{array}$ & $\begin{array}{c}75.91 \\
* * *\end{array}$ & $\begin{array}{c}46.87 \\
* * *\end{array}$ & $\begin{array}{l}19.5 \\
* * *\end{array}$ & $\begin{array}{c}10.09 \\
* * *\end{array}$ & $\begin{array}{c}28.59 \\
* * *\end{array}$ & $\begin{array}{c}3.47 \\
*\end{array}$ & $\begin{array}{c}99.65 \\
* * *\end{array}$ & $\begin{array}{c}16.78 \\
* * *\end{array}$ & $\begin{array}{c}2132.23 \\
* * *\end{array}$ & $\begin{array}{c}14.73 \\
* * *\end{array}$ & $\begin{array}{c}102.88 \\
* * *\end{array}$ \\
\hline Plant & 1 & $\begin{array}{c}65.24 \\
* * *\end{array}$ & $\begin{array}{c}25.33 \\
* * *\end{array}$ & $\begin{array}{c}13.52 \\
* *\end{array}$ & $\begin{array}{c}0.14 \\
\mathrm{~ns}\end{array}$ & $\begin{array}{c}2.55 \\
\mathrm{~ns}\end{array}$ & $\begin{array}{c}14.74 \\
* * *\end{array}$ & $\begin{array}{c}12.16 \\
* *\end{array}$ & $\begin{array}{c}2.54 \\
\mathrm{~ns}\end{array}$ & $\begin{array}{l}1.9 \\
\mathrm{~ns}\end{array}$ & $\begin{array}{c}19.04 \\
* * *\end{array}$ & $\begin{array}{c}85.22 \\
* * *\end{array}$ & $\begin{array}{c}0.08 \\
\mathrm{~ns}\end{array}$ & $\begin{array}{c}30.13 \\
* * *\end{array}$ \\
\hline $\begin{array}{l}\text { Site } \times \\
\text { Plant }\end{array}$ & 2 & $\begin{array}{c}27.05 \\
* * *\end{array}$ & $\begin{array}{c}2.29 \\
\mathrm{~ns}\end{array}$ & $\begin{array}{c}7.53 \\
* *\end{array}$ & 0.52 & $\begin{array}{c}0.55 \\
\mathrm{~ns}\end{array}$ & 0.83 & $\begin{array}{c}4.19 \\
*\end{array}$ & $\begin{array}{c}3.31 \\
\mathrm{~ns}\end{array}$ & 0.94 & 2.8 & $\begin{array}{c}7.68 \\
* *\end{array}$ & $\begin{array}{c}2.66 \\
\mathrm{~ns}\end{array}$ & $\begin{array}{c}12.29 \\
* * *\end{array}$ \\
\hline
\end{tabular}

\begin{tabular}{cccc}
\hline Source & DF & TBC & TFC \\
\hline Site & 2 & 660.62 & 60.40 \\
& & $* * *$ & $* * *$ \\
Plant & 1 & 235.15 & 63.65 \\
& & $* * *$ & $* * *$ \\
Site X & 2 & 120.48 & 2.58 \\
Plant & & $* * *$ & $\mathrm{~ns}$ \\
\hline
\end{tabular}

Probability levels: *: $\mathrm{P}<0.05$; ** $\mathrm{P}<0.01$; ${ }^{* *} \mathrm{P}<0.0001 . \mathrm{OM}$ : soil organic matter; TBC: total bacterial count; TFC: total fungal count. 


\subsubsection{Mycorrhizal colonization}

As expected, soil $\mathrm{pH}$ also had a significant effect on the degree of mycorrhizal colonization (Fig. 2). The degree of colonization was highest at $\mathrm{pH} 5.5$ with no significant difference at $\mathrm{pH} 6.5$ and 7.5, while the degree of colonization was significantly lower at both $\mathrm{pH} 4.5$ and $\mathrm{pH}$ 8.0. There was no significant difference in the mycorrhizal structures such as vesicles, arbuscules, and hyphae among the four soil $\mathrm{pH}$ levels (data not shown).

When the $\mathrm{pH}$ treatments were analyzed independently there was no strong correlation between the root colonization by mycorrhizal fungi and plant growth parameters or the leaf concentration of elements. However when the samples were pooled there was a strong correlation between the degree of mycorrhizal colonization and plant growth parameters as well as the leaf element status (Table 3.3). Additionally, there was a significant correlation between the degree of mycorrhizal colonization and element uptake by L. microphyllum. 


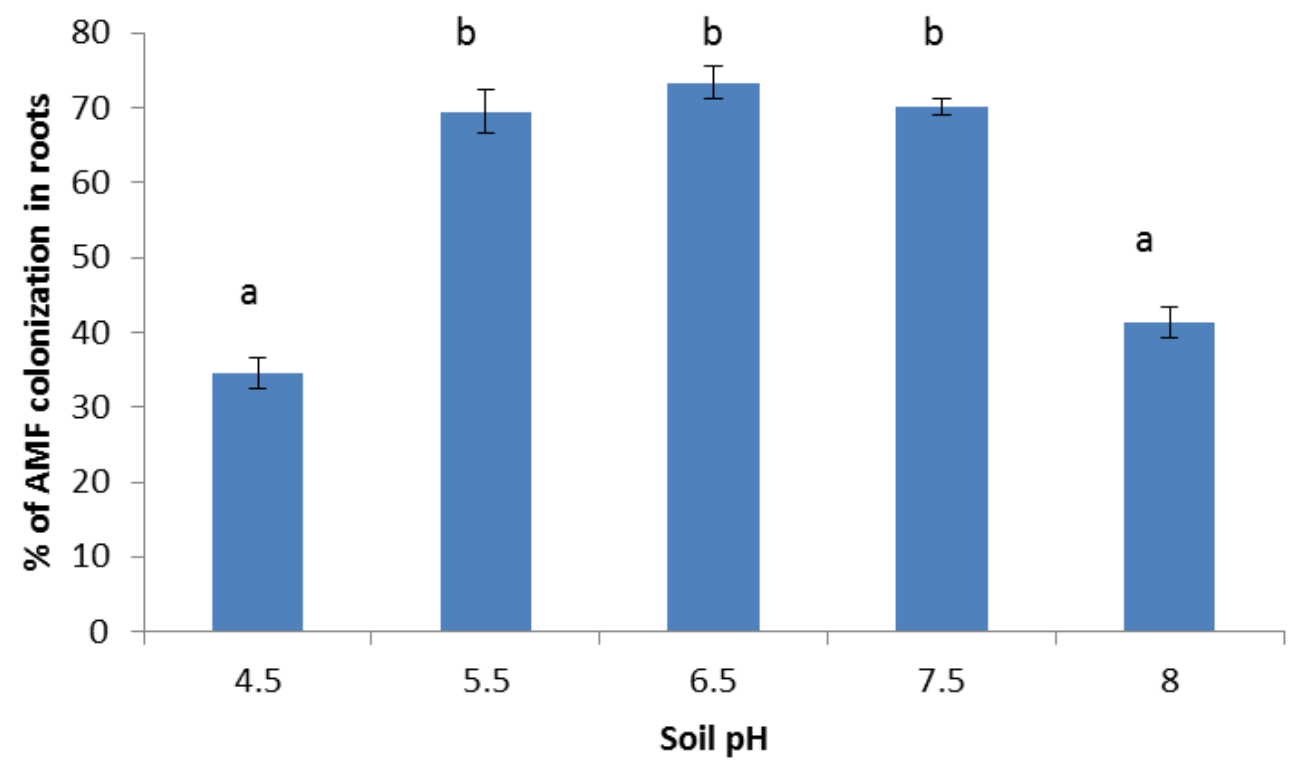

Figure 0.2 Mean value ( $\pm \mathrm{SE}$ ) of degree of mycorrhizal colonization at different $\mathrm{pH}$ levels. Similar letters represent no significant difference at $p \leq 0.05$.

Table 0.3 Correlation coefficients of plant growth parameters and leaf element concentration with the degree of mycorrhizal colonization.

\begin{tabular}{ccc}
\hline Parameter & $\begin{array}{c}\text { Pearson Correlation } \\
\text { Coefficients }\end{array}$ & P value \\
\hline Biomass & 0.64 & 0.0002 \\
RGR & 0.65 & $<.0001$ \\
SLA & 0.67 & $<.0001$ \\
RhiMR & 0.78 & $<.0001$ \\
RMR & -0.65 & 0.0001 \\
Photosynthesis & 0.64 & 0.0001 \\
Al & -0.43 & 0.0191 \\
Fe & -0.45 & 0.0136 \\
N & 0.87 & $<.0001$ \\
\hline
\end{tabular}




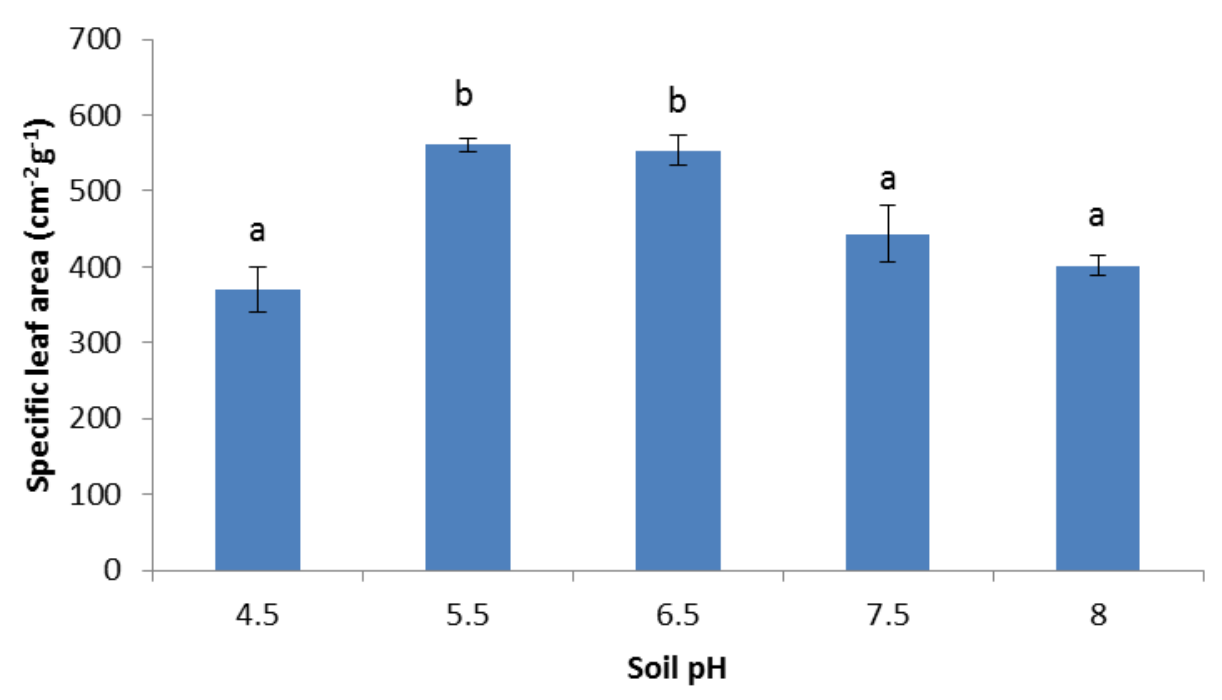

Figure 0.3 Mean $( \pm \mathrm{SE})$ value specific leaf area (SLA) at different $\mathrm{pH}$ levels. Similar letters represent no significant difference at $\mathrm{p} \leq 0.05$.
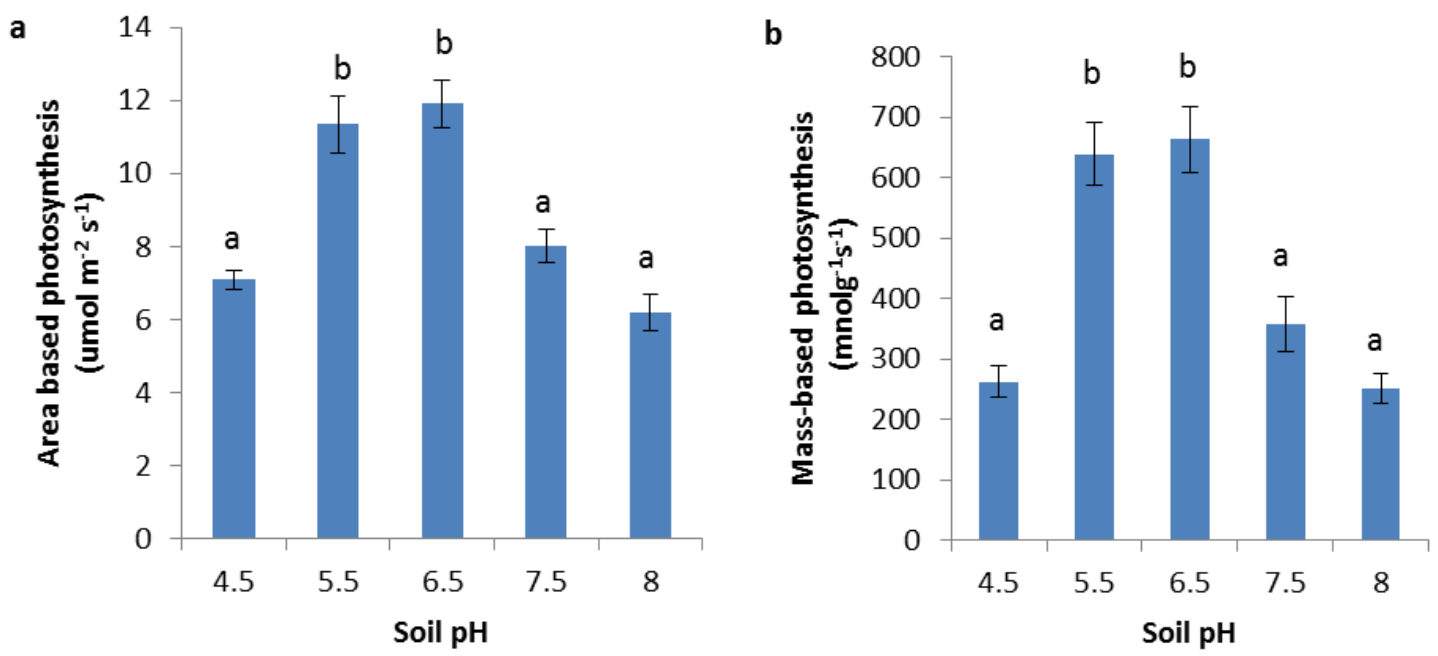

Figure 0.4 Mean $( \pm \mathrm{SE})$ value of area based photosynthesis (a), mass based photosynthesis (b) at different $\mathrm{pH}$ levels. Similar letters represent no significant difference at $\mathrm{p} \leq 0.05$. 

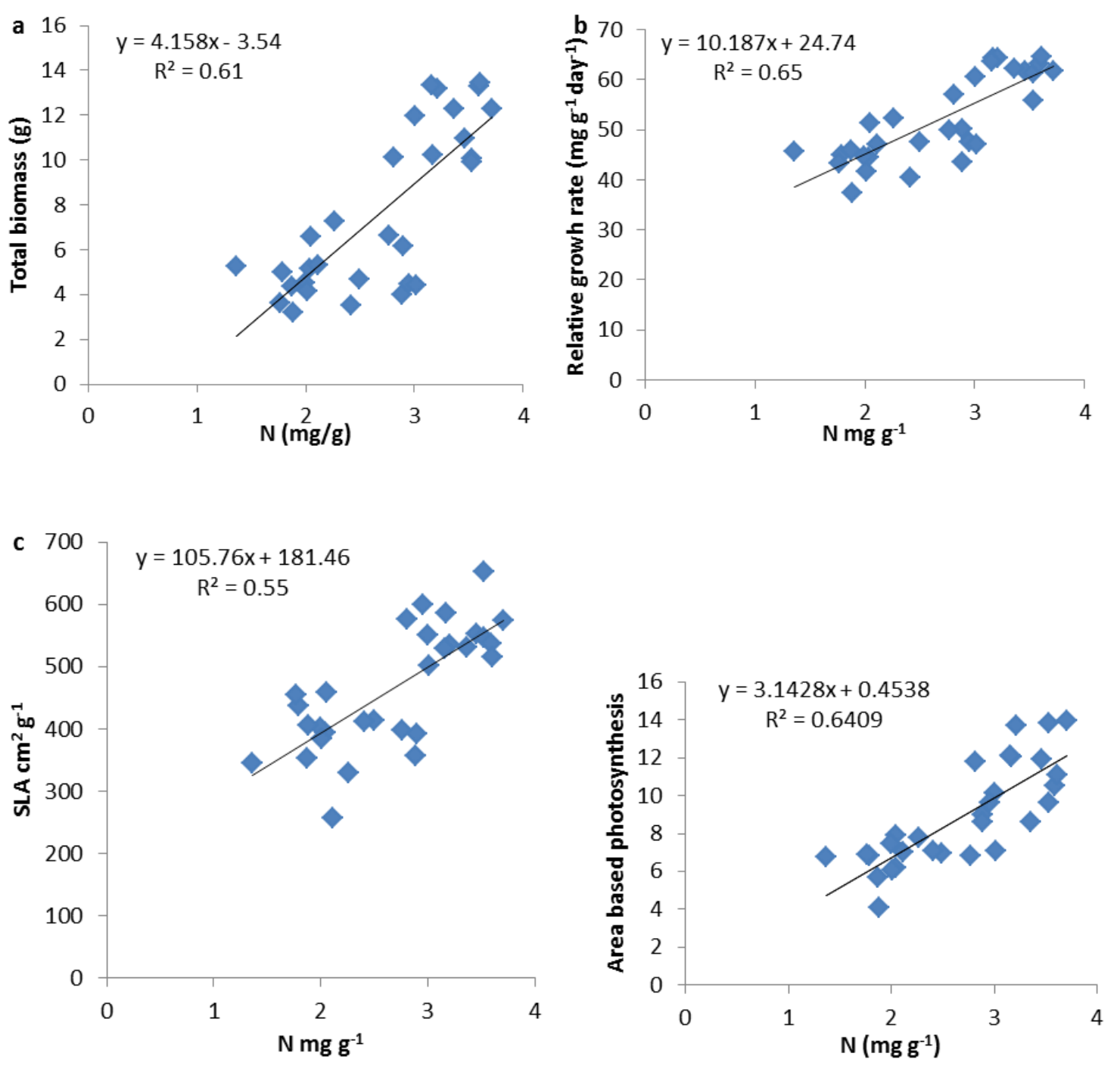

Figure 0.5 Linear regression of leaf nitrogen concentration and (a) total biomass, (b) specific leaf area (SLA); (c) relative growth rate (RGR); (d) area based photosynthesis $\left(\mu \mathrm{mol} \mathrm{m} \mathrm{s}^{-1}\right)$ 


\subsection{Discussion}

Different soil $\mathrm{pH}$ levels were selected to include a wide range of soil $\mathrm{pH}$ where $L$. microphyllum has been reported to grow in its native range in Australia and the invaded regions in Florida. At soil $\mathrm{pH} 4.5$ and 8.0 the plants were noticeably smaller and grew less vigorously compared to the other treatments. Soil $\mathrm{pH} 5.5$ and 6.5 provided the most favorable conditions for the nutrient uptake, growth and biomass accumulation. This result was expected for L. microphyllum because extensive growth occurs in slightly acidic soils of Florida. Few other ferns in Florida have also been reported to prefer soil $\mathrm{pH}$ close to 6.0; field study by Van Loan (2006) showed that Lygodium japonicum, another pest plant species in Florida, was present in sites with soil $\mathrm{pH}$ 6.0. Similarly, Mathur (1980) reported that the fern Rumohra adiantiformis requires soil $\mathrm{pH}$ between 5.5 and 6.0 for optimal growth. However, as opposed to my expectation the plants grown in alkaline soils survived, maintained a fair growth rate and produced fertile fronds.

Past research has shown that invasive species have a higher tolerance to low soil $\mathrm{pH}$ and have superior ability to assimilate nutrients (Thompson et al. 1987; Emery and Perry 1995). In its native range in Australia, L. microphyllum grows in highly acidic soils (soil $\mathrm{pH}$ range 3.9-4.7) (Chapter 2), this adaptive capability of L. microphyllum to acidic soils was visible in my study. Contrary to my expectation plants grown in soil $\mathrm{pH} 8.0$ maintained a fair growth rate, but the decline in the RGR was visible with the increasing soil $\mathrm{pH}$ thus further increasing the soil $\mathrm{pH}$ could provide a desired outcome, although its potential negative impact on native flora (both plants and microorganisms) would need to be assessed. The high RGR of plants grown in soil $\mathrm{pH} 5.5$ and 6.5 plants corresponded to the higher mass-based photosynthesis, which resulted from the increased SLA as well as 
area-based photosynthesis. My results indicate that variation in RGR was explained by the variation in photosynthetic capacity of L. microphyllum and SLA.

My results show that the biomass allocation to the belowground structures was different across the different $\mathrm{pH}$ treatments. An unexpected result was that plants grown in strongly acidic soils allocated the highest biomass to the roots compared to the other plants at the cost of biomass allocation to the rhizomes. The higher biomass allocation to the roots in acidic soils contradict the common assumption that Al toxicity in acidic soil causes a significant reduction in root growth by inhibiting cell division in the root apical meristem (Farid 1991; Ryan et al. 1993; Crawford \& Wilkens 1998) resulting in reduced water and nutrient uptake. Abhramhamsen (1983) suggested that certain plant species have the ability to translocate the Al absorbed from roots to other parts of plant to avoid Al toxicity, element concentration in the roots were not measured in my study but this may be one explanation for the extensive root growth in the plants in soil $\mathrm{pH} 4.5$ and would need to be substantiated in future research. Additionally, there is a possibility of root exudates secretion by L. microphyllum as a defense mechanism to Al toxicity. The ability to avoid Al toxicity in acidic soils could in part explain the extensive growth of $L$. microphyllum in the sand mine spoils with toxic levels of Al and Fe in central Florida (Soti, pers. obser.). The $\mathrm{pH}$ of soil in direct contact with the roots was not possible to measure without disturbing the plants so I do not know if the L. microphyllum plants had any influence on the soil in direct contact with the roots.

Another possibility is that extensive root growth is necessary for the acquisition of water and nutrients for plants; in my study water was not a limiting factor, but nutrients could have been limiting resource for plants growing in acidic soil. Schindelbeck and 
Riha (1988) and Kidd \& Proctor (2001), have found that decrease in soil $\mathrm{pH}$ caused an increased biomass allocation to roots; Bates et al. (2002) found that when the soil $\mathrm{pH}$ was lower than 4.4 the root: shoot ratio increased in Vitis labruscana L. plants. Phenotypic plasticity is one of the key characteristic of invasive plants which allows them to adapt to a wide range of habitat types (Claridge \& Franklin, 2002). Previous studies have shown that L. microphyllum is extremely plastic in its ability to respond to myriad environmental conditions, including plasticity in reproduction, physiology, allocation, and morphology (see: Lott et al. 2003, Gandiaga et al. 2009, Volin et al. 2004, 2010 and 2013). In the present study, my results show that $L$. microphyllum adapts to low nutrient conditions in acidic soil by increasing biomass allocation to the roots. Phenotypic plasticity in response to environmental conditions has been reported in Melaleuca quinquenervia, a flowering tree which shares habitat with L. microphyllum in its native range in Australia and is invasive in most of the regions in south Florida, where $97 \%$ of its variation was accounted for soil pH (Kaufman \& Smouse, 2001).

Soil $\mathrm{pH}$ had a significant effect on the element uptake by L. microphyllum. Higher concentration of $\mathrm{Al}$ in the leaves of plants growing in acidic soils did not substantially alter the growth parameters of L. microphyllum. It is reported that $\mathrm{Al}$ and Mn toxicity occur in soil when the $\mathrm{pH}$ is below 4.8 (Slattery et al. 1999), but $L$, microphyllum plants grown in strongly acidic soils did not show any sign of toxicity. Marschner (1995) suggested that $\mathrm{N}$ acts as growth regulator itself and is tied into plant growth allocation by direct involvement with plant growth regulators as well. In my study, the major element influencing plant growth was N. Its concentration was significantly higher in the plants grown in soil $\mathrm{pH} 5.5$ and 6.5 , and strongly correlated with the RGR, photosynthesis, 
RhiMR, and SLA. A positive correlation between leaf N concentration and RGR, SLA, and photosynthetic capacity have reported for a wide range of plants (Poorter et al. 1990; Grime, 1991; Poorter and Bergkotte 1992; Reich et al. 1994; Nielsen et al. 1996; Cornelissen et al. 1997; Reich et al. 1998). Phosphorus is reported to form insoluble compounds under high soil $\mathrm{pH}$ conditions, causing $\mathrm{P}$ deficiency in plants (Shen et al. 2011). In my study there was no significant difference in the leaf concentration of $P$ among the various soil $\mathrm{pH}$ treatments; this could have been in part influenced by arbuscular mycorrhizal fungi (AMF). Root colonization by AMF colonization is reported to be most positive when the soil is P-limited (Hoeksema et al. 2010), but in my study the plants were not limited by nutrients. However, AMF did have a significant effect on the $\mathrm{P}$ accumulation in the leaves of L. microphyllum.

L. microphyllum is reported to have most of the traits of an aggressive invader, including its reproductive characteristics, and its lack of a significant pathogens or herbivores in its introduced range. My results show that L. microphyllum can maintain a fair growth rate over a wide range of soil $\mathrm{pH}$, indicating a continuing threat to most uninvaded sites. Soil $\mathrm{pH}$ levels 5.5- 6.5 were optimal for rapid growth and biomass accumulation.

Burning and application of herbicides are the most commonly used methods to control L. microphyllum. Loveless (1959) found that burning raises the soil $\mathrm{pH}$ in tree islands of the northern Everglades. Furthermore, the fate of the chemical herbicides used to control L. microphyllum and other exotic invasive species depends upon soil $\mathrm{pH}$. I found that increasing soil $\mathrm{pH}$ from highly acidic to near-neutral $\mathrm{pH}$ provides a more favorable condition for L. microphyllum growth. Prescribed burning, which causes a 
temporary increase in soil $\mathrm{pH}$, is a widely used method to control L. microphyllum, but my study shows that L. microphyllum could be benefitting from the slight increase in soil $\mathrm{pH}$ resulting from fire as well as the release of nutrients that are associated with burning. In my study, L. microphyllum had highest growth at neutral soil $\mathrm{pH}$ and began to show a significant decrease at a soil $\mathrm{pH}$ of 8.0 , likely further growth reductions would happen in even more alkaline soils. Thus, raising soil $\mathrm{pH}$ may be a possible management option to explore in the future, but increasing the soil $\mathrm{pH}$ would need to be studied carefully for its potential adverse effects to native flora as well, including both native plants and soil microorganisms.

\section{Acknowledgements}

I thank Steven Oberbauer, Department of Biological Sciences, Florida International University and Stewart T Reed, USDA, ARS, Miami, Florida for their help in analyzing the samples. This research was supported by the Dissertation Evidence Acquisition Fellowship, to Pushpa Soti from the Graduate School, Florida International University.

\section{References}

Abrahamsen G (1983) Sulphur pollution: $\mathrm{Ca}, \mathrm{Mg}$ and $\mathrm{Al}$ in soil and soil water and possible effects on forest trees. In: Effects of accumulation of air pollutants in forest ecosystems. Springer, pp 207-218

Alam SM, Naqvi SSM, Ansari R (1999) Impact of soil $\mathrm{pH}$ on nutrient uptake by crop plants. Handbook of Plant and Crop Stress:51-60

Baker HG (1974) The evolution of weeds. Annu Rev Ecol Syst 5:1-24

Bates TR, Dunst RM, Taft T, Vercant M (2002) The vegetative response of 'Concord' 
grapevines to soil pH. HortScience 37:890-893

Black CA (1968) Soil-plant relationships. Soil-plant relationships.

Buchanan G, Hoveland C, Harris M (1975) Response of weeds to soil pH. Weed Sci:473477

Cornelissen JHC, Werger MJA, CastroDiez P, vanRheenen JWA, Rowland AP (1997)

Foliar nutrients in relation to growth, allocation and leaf traits in seedlings of a wide range of woody plant species and types. Oecologia 111:460-469

Crawford SA, Wilkens S (1998) Effect of aluminium on root elongation in two Australian perennial grasses. Aust J Plant Physiol 25:165-171

De Boer W, Kowalchuk G (2001) Nitrification in acid soils: micro-organisms and mechanisms. Soil Biol Biochem 33:853-866

Dupre C, Wessberg C, Diekmann M (2002) Species richness in deciduous forests: Effects of species pools and environmental variables. Journal of Vegetation Science 13:505-516

Emery SL, Perry JA (1996) Decomposition rates and phosphorus concentrations of purple Loosestrife (Lythrum salicaria) and cattail (Typha spp) in fourteen Minnesota wetlands. Hydrobiologia 323:129-138

Foy CD (1992) Soil chemical factors limiting plant root growth. In: Limitations to plant root growth. Springer, pp 97-149

Gandiaga S, Volin JC, Kruger EL, Kitajima K (2009) Effects of hydrology on the growth and physiology of an invasive exotic, Lygodium microphyllum (Old World climbing fern). Weed Res 49:283-290

Gould WA, Walker MD (1999) Plant communities and landscape diversity along a Canadian arctic river. Journal of Vegetation Science 10:537-548

Green N, Graham S, Schenck N (1976) The influence of $\mathrm{pH}$ on the germination of vesicular-arbuscular mycorrhizal spores. Mycologia 68:929-934

Grime JP (1973) Competitive exclusion in herbaceous vegetation. Nature 242:344-347

Hildebrandt U, Regvar M, Bothe H (2007) Arbuscular mycorrhiza and heavy metal tolerance. Phytochemistry 68:139-146

Hill SB, Ramsay J (1977) Weeds as indicators of soil conditions. The McDonald Journal $38: 8-12$ 
Hoeksema JD, Chaudhary VB, Gehring CA, Johnson NC, Karst J, Koide RT, Pringle A, Zabinski C, Bever JD, Moore JC, Wilson GWT, Klironomos JN, Umbanhowar J (2010) A meta-analysis of context-dependency in plant response to inoculation with mycorrhizal fungi. Ecol Lett 13:394-407

Jan F (1991) Aluminum Effects on Growth, Nutrient Net Uptake and Transport in 3 Rice (Oryza-Sativa) Cultivars with Different Sensitivity to Aluminum. Physiol Plantarum $83: 441-448$

Johnson CE (2002) Cation exchange properties of acid forest soils of the northeastern USA. Eur J Soil Sci 53:271-282

Kaufman SR, Smouse PE (2001) Comparing indigenous and introduced populations of Melaleuca quinquenervia (Cav.) Blake: response of seedlings to water and $\mathrm{pH}$ levels. Oecologia 127:487-494

Kidd PS, Proctor J (2001) Why plants grow poorly on very acid soils: are ecologists missing the obvious? J Exp Bot 52:791-799

Kinraide TB (1993) Aluminum Enhancement of Plant-Growth in Acid Rooting Media - a Case of Reciprocal Alleviation of Toxicity by 2 Toxic Cations. Physiol Plantarum 88:619-625

Kruger EL, Volin JC (2006) Reexamining the empirical relation between plant growth and leaf photosynthesis. Functional Plant Biology 33:421-429

Larcher W (1996) Physiological plant ecology. Acta Physiologiae Plantarum 18:183-184

Liu F, De Cristofaro A, Violante A (2001) Effect of pH, phosphate and oxalate on the adsorption/desorption of arsenate on/from goethite. Soil Sci 166:197-208

Lott MS, Volin JC, Pemberton RW, Austin DE (2003) The reproductive biology of the invasive ferns Lygodium microphyllum and L. japonicum (Schizaeaceae): Implications for invasive potential. Am J Bot 90:1144-1152

Marschner H (1995) Mineral nutrition of higher plants. Orlando (FL) 7

Mathur D (1980) Influence of soil acidity and liming on the production of Leatherleaf Fern. University of Florida, IFAS, Agricultural Research Center

McConnaughay KDM, Coleman JS (1999) Biomass allocation in plants: Ontogeny or optimality? A test along three resource gradients. Ecology 80:2581-2593

Mooney HA, Cleland EE (2001) The evolutionary impact of invasive species. Proc Natl Acad Sci USA 98:5446-5451 
Nicol GW, Leininger S, Schleper C, Prosser JI (2008) The influence of soil pH on the diversity, abundance and transcriptional activity of ammonia oxidizing archaea and bacteria. Environ Microbiol 10:2966-2978

Nielsen SL, Enriquez S, Duarte CM, SandJensen K (1996) Scaling maximum growth rates across photosynthetic organisms. Funct Ecol 10:167-175

Poorter H, Bergkotte M (1992) Chemical-composition of 24 wild-species differing in Relative Growth-Rate. Plant Cell and Environment 15:221-229

Poorter H, Remkes C, Lambers H (1990) Carbon and nitrogen economy of 24 wildspecies differing in relative growth-rate. Plant Physiol 94:621-627

Prentis PJ, Wilson JR, Dormontt EE, Richardson DM, Lowe AJ (2008) Adaptive evolution in invasive species. Trends Plant Sci 13:288-294

Reich PB, Ellsworth DS, Walters MB (1998) Leaf structure (specific leaf area) modulates photosynthesis-nitrogen relations: evidence from within and across species and functional groups. Funct Ecol 12:948-958

Reich PB, Walters MB (1994) Photosynthesis-nitrogen relations in Amazonian tree species .2. Variation in nitrogen vis-a-vis specific leaf-area influences mass-based and area-based expressions. Oecologia 97:73-81

Rorison I (1980) The effects of soil acidity on nutrient availability and plant response. In: Effects of acid precipitation on terrestrial ecosystems. Springer, pp 283-304

Ryan PR, Ditomaso JM, Kochian LV (1993) Aluminum toxicity in roots - an investigation of spatial sensitivity and the role of the root cap. J Exp Bot 44:437-446

Schindelbeck RR, Riha SJ (1988) Soil acidity, and the growth, biomass partitioning and leaf mineral-composition of Honeylocust (Gleditsia-Triacanthos L) seedlings. Tree Physiol 4:361-369

Shen J, Yuan L, Zhang J, Li H, Bai Z, Chen X, Zhang W, Zhang F (2011) Phosphorus dynamics: from soil to plant. Plant Physiol 156:997-1005

Shen QR, Ran W, Cao ZH (2003) Mechanisms of nitrite accumulation occurring in soil nitrification. Chemosphere 50:747-753

Stephenson RJ, Rechcigl JE (1991) Effects of dolomite and gypsum on weeds. Commun Soil Sci Plant Anal 22:1569-1579

Storer DA (1984) A simple high sample volume ashing procedure for determination of soil organic-matter. Commun Soil Sci Plant Anal 15:759-772 
Thompson DQ, Stuckey RL, Thompson EB (1987) Spread, impact, and control of purple loosestrife (Lythrum salicaria) in North American wetlands

Tyler G (1999) Plant distribution and soil-plant interactions on shallow soils. Acta Phytogeogr Suec 84:21-32

United States. Dept. of Agriculture (1957) Soil. US Government Printing Office

Van Loan AN (2006) Japanese climbing fern: The insidious "other" Lygodium. Wildland Weeds 9:25-27

Volin JC, Kruger EL, Lindroth RL (2002) Responses of deciduous broadleaf trees to defoliation in a CO2 enriched atmosphere. Tree Physiol 22:435-448

Volin JC, Lott MS, Muss JD, Owen D (2004) Predicting rapid invasion of the florida everglades by old world climbing fern (Lygodium microphyllum). Divers Distrib 10:439446

Volin JC, Kruger EL, Volin VC, Tobin MF, Kitajima K (2010) Does release from natural belowground enemies help explain the invasiveness of Lygodium microphyllum? A crosscontinental comparison. Plant Ecol 208:223-234 


\section{ALTERED SOIL BIOGEOCHEMICAL PROPERTIES BY EXOTIC INVASIVE OLD WORLD CLIMBING FERN (LYGODIUM MICROPHYLLUM) IN FLORIDA: IMPLICATIONS FOR MANAGEMENT AND RESTORATION}

Soti Pushpa G., Jayachandran Krish (2013) Altered soil biogeochemical properties by exotic invasive Old World climbing fern (Lygodium microphyllum) in Florida: implications for management and restoration. (In Review) Weed Science.

Abstract

Invasion by exotic species threatens ecosystems not only by competing with native species for resources, but also by having a substantial impact on the structure, function, and composition of the belowground ecosystem by modifying the physical, chemical, and biological properties of the soil. Old World climbing fern (Lygodium microphyllum) is one of the worst non-native plant species and has become a serious threat to the greater Everglades ecosystem of south Florida. In the present study, I analyzed the effects of Old World climbing fern on surface soil characteristics at invaded sites in Florida. I compared soil characteristics of six invaded and adjacent uninvaded plots at three different locations. My results show that the fern can grow and thrive in a wide range of soil types and the impact on the soil was site specific with effects being more prominent in sites with low nutrient status. Additionally, there were significant differences in the soil nutrient status and microbial population in the invaded and uninvaded sites. Sites with Old World climbing fern had significantly higher nutrient concentrations that correlated with higher soil organic matter. Overall my results indicate that this exotic pest plant can alter its belowground environment to its own benefit by enhancing the soil nutrient status by adding soil organic matter. 
Nomenclature: Old World climbing fern, Lygodium microphyllum

Key words: invasive plants, nutrient cycle, $\mathrm{pH}$, soil organic matter

\subsection{Introduction}

Invasion by exotic invasive plants has a substantial impact on the structure, function, and composition of the native communities (Evans et al. 2001; Ehrenfeld 2003; Rice and Emery 2003; Vila et al. 2011). Existing literature provides evidence that invasive plant species can modify physical, chemical, and biological properties of the soil including inputs and cycling of nutrients (Ehrenfeld 2003; Hawkes et al. 2005; Sperry et al. 2006), soil pH (Kourtev et al. 2003), soil organic matter and aggregation (Saggar et al. 1999). Invasive plants also modify the biotic composition of the soil by affecting the soil food web (Duda et al. 2003), total microbial communities (Kourtev et al. 2003), and fungal communities (Hawkes et al. 2006). Some invasive plants are also reported to exude allelochemicals which could inhibit soil borne pathogens, defend against disease, and repel insects (Yuan et al. 2012; and references there in). However, the documented impacts of invasive species on soil characteristics are diverse. While most of the studies have reported increased soil nutrient stock in invaded sites compared to non-invaded sites creating a positive feedback benefiting invasive species (Duda et al. 2003; Vanderhoeven et al. 2005; Liao et al. 2008; Perkins 2011), some other studies have shown negative feedback (Ley and D'Antonio 1998; Mack and D'Antonio 1998; Leary et al. 2006). A meta-analysis of litter decomposition rates by Liao et al. (2008) showed that the litter decomposition rate of the invasive plants was on average, $117 \%$ faster than the cooccurring native species. However, Ehrenfeld (2010) demonstrated slower rates of leaf 
decay in exotic species compared with the native plant species. The species-specific variation was attributed to be the most important factor in determining the decomposition rates (Hoorens et al. 2003), as each plant species has a unique biochemical composition, including the nitrogen concentration and carbon-to-nitrogen ratio. Gordon (1998) in her meta-analysis has shown that out of 31 species considered most invasive, 12-20 (3964\%) potentially alter the ecosystem properties of geomorphology, hydrology, biogeochemistry, and disturbance in Florida.

Lygodium microphyllum (Old World Climbing Fern) is a highly invasive species distributed throughout the freshwater and moist habitats of south Florida. It is common in cypress swamp, pine flatlands, wet prairies, sawgrass marshes, mangrove communities, and Everglades tree islands (Pemberton and Ferriter, 1998). Once established, $L$. microphyllum dominates both understory and overstory native wetland habitats. It has the ability to grow in varying hydrological (Gandiaga et al. 2009), nutrient (Volin et al. 2010), soil pH (Chapter 2), and light gradients (Volin et al. 2004). Results from Chapter 2 also show that L. microphyllum is highly dependent on mycorrhizal fungi for growth and phosphorus uptake; thus, fungi could highly enhance its invasiveness. According to an estimate by (Ferriter and Pernas 2006), L. microphyllum covers 183,080 acres in the entire South/Central Florida region. Managing L. microphyllum has been a significant challenge for land resource managers and researchers as a consequence of its extensive rapid invasion in natural areas of south Florida.

Aboveground changes caused by L. microphyllum in south Florida natural areas are obvious and have remained the focus of land managers and researchers, but belowground changes caused by the plant-soil feedback have not gained much research 
interest so far. However, for the management of this exotic invasive and restoration of invaded sites, it is essential to understand the direct and indirect impacts of $L$. microphyllum on soil processes and how these changes can influence the successful management of invaded areas. If L. microphyllum can successfully modify soil processes such as nutrient cycling, litter decomposition, and soil microbial communities, simply removing it may not be an effective management strategy. Furthermore, it is necessary to assess the effects of soil modification by L. microphyllum on the invasability of plant communities, whether this modification facilitates other invasive species and if it has a negative impact on the native species. The aim of the present is to obtain baseline information on how L. microphyllum alters the physical, chemical, and microbial characteristics of the invaded sites, which would help to better understand and interpret effects of soil additives to control this pest plant species. I compared an invaded and a nearby non-invaded site to examine the impacts of L. microphyllum invasion on the topsoil chemistry and microbial populations at three sites with different soil characteristics.

\subsection{Methods}

\subsubsection{Sampling sites}

Two sites in south Florida were selected for the comparison of soil characteristics: Tree Tops Park (Broward County) and Jonathan Dickinson Park (Martin County), and one site in central Florida, the Trustcorp/Tiedtke property (Lake County). These sites were paired to include one plot with L. microphyllum and another with native plants. The sites were selected on the basis of the following criteria: 1) a well-established 
monospecific population; 2) sites that had not undergone any management activities for at least the last five years; 3) homogeneous soil type under both the native and invasive plants; and 4) adjacent plots with native plants. Site location and dominant vegetation in the sampling sites are given in Table 4.1.

Table 0.1 Site locations, vegetation, and site type.

\begin{tabular}{|c|c|c|c|}
\hline Site & Coordinates & $\begin{array}{l}\text { Dominant species in the } \\
\text { invaded sites }\end{array}$ & Site Type \\
\hline $\begin{array}{l}\text { Tree Tops } \\
\text { Park }\end{array}$ & $\begin{array}{l}26^{\circ} 4^{\prime} 0.04^{\prime \prime} \mathrm{N}, \\
80^{\circ} 16^{\prime} 5.88^{\prime \prime} \mathrm{W}\end{array}$ & $\begin{array}{l}\text { Chrysobalanus icaco, Osmunda } \\
\text { regalis var. spectabilis, Annona } \\
\text { glabra }\end{array}$ & $\begin{array}{l}\text { County Park, } \\
\text { disturbed } \\
\text { habitat }\end{array}$ \\
\hline $\begin{array}{l}\text { Jonathan } \\
\text { Dickinson }\end{array}$ & $\begin{array}{l}27^{\circ} 0{ }^{\prime} 37.33^{\prime \prime} \mathrm{N} \\
80^{\circ} 7^{\prime} 20.28^{\prime \prime} \mathrm{W}\end{array}$ & $\begin{array}{l}\text { Pinus elliottii, Myrica cerifera, } \\
\text { Ilex cassine, Serenoa repens }\end{array}$ & $\begin{array}{l}\text { State Park, } \\
\text { undisturbed } \\
\text { habitat }\end{array}$ \\
\hline $\begin{array}{l}\text { Central } \\
\text { Florida }\end{array}$ & $\begin{array}{l}28^{\circ} 23^{\prime} 4.03^{\prime \prime} \mathrm{N}, \\
81^{\circ} 44^{\prime} 41.30^{\prime \prime} \mathrm{W}\end{array}$ & $\begin{array}{l}\text { Pinus elliottii, Quercus } \\
\text { geminata, Quercus nigra, } \\
\text { Serenoa repens }\end{array}$ & $\begin{array}{l}\text { Private } \\
\text { property, sand } \\
\text { mine spoil }\end{array}$ \\
\hline
\end{tabular}




\subsubsection{Soil sampling and analysis}

At each sampling site, six $1 \mathrm{~m} \times 1 \mathrm{~m}$ plots were selected randomly and soil from the 10-15 cm deep zone was collected from each of the four corners and the center of each plot with a soil corer (ø $18 \mathrm{~mm})$ and mixed homogeneously into one bulk sample for each plot. The soil samples from south Florida were transported to the laboratory in a cooler and the samples from central Florida were cooled to $4^{\circ} \mathrm{C}$ and shipped overnight. A portion of the soil samples from all sites were stored in a $4^{\circ} \mathrm{C}$ refrigerator until analysis for biological measurements. A small portion of each soil sample was air dried and passed through a $2 \mathrm{~mm}$ sieve for analysis of physicochemical properties. Those subsamples were then ground to fine powder with a mortar and pestle, and stored at room temperature in air-tight containers for further analysis of nutrients and trace elements. The soil $\mathrm{pH}$ was measured with a $\mathrm{pH}$ meter, (soil: solution ratio 1:2 in water), texture was measured by the hydrometer method, and total organic matter was measured based on the standard loss-on-ignition method $\left(500^{\circ} \mathrm{C}, 5\right.$ hours; Storer 1984). Total C and N were measured with a Truspec $\mathrm{CN}$ analyzer. Total $\mathrm{Ca}, \mathrm{Fe}, \mathrm{Al}, \mathrm{Mg}, \mathrm{K}, \mathrm{Mn}$, and $\mathrm{P}$ were measured with an ICP-MS at USDA, ARS Laboratory, Homestead, Florida after following the acid digestion Method 3050 (USEPA 1996). One gram of each finely ground soil sample was transferred to a large glass tube and mixed with $10 \mathrm{ml}$ of $30 \%$ $\mathrm{HNO}_{3}$. The tubes were covered with a vapor recovery system and heated to $95 \pm 5^{\circ} \mathrm{C}$ and refluxed for 10 minutes without boiling under the hood in a heating block maintained with a Partlow Mic 6000 Profile Process Controller. After cooling to $40^{\circ} \mathrm{C}, 5 \mathrm{ml}$ of concentrated $\mathrm{HNO}_{3}$ was added and the sample was heated again until no brown fumes were given off. After cooling to $40^{\circ} \mathrm{C}, 2 \mathrm{ml}$ of DI water and $3 \mathrm{ml}$ of $30 \% \mathrm{H}_{2} \mathrm{O}_{2}$ was added 
to each tube and heated until the effervescence subsided. The samples were cooled and diluted to $50 \mathrm{ml}$ with DI water, centrifuged at $2000 \mathrm{rpm}$ for 10 minutes and filtered with Whatman No. 41 filter paper.

The total colony-forming-units (CFU) of bacteria and fungi were determined by the standard dilution spread plate method as described by Seely and VanDemark (1981). The dry equivalent of one gram soil was mixed in $9 \mathrm{ml}$ sterile water (autoclaved) and was diluted serially. Samples were vigorously mixed during dilution to assist in dislodging the bacteria from the soil particles. A serial dilution of $10^{-2}, 10^{-3}, 10^{-4}$, and $10^{-5}$ was made for fungi and $10^{-4}, 10^{-5}, 10^{-6}$, and $10^{-7}$ for bacteria. A total of $100 \mu \mathrm{l}$ of diluted soil suspension was spread on three plates per soil sample for both bacteria and fungi at each dilution level. Nutrient agar containing cycloheximide solution (to prevent fungal growth) was used for bacteria and Rose Bengal Agar (RBA) with streptomycine sulphate (to prevent bacteria growth) was used for the estimation of fungal colonization. Sterilized water was spread on the agar plates that were used as controls.

\subsubsection{Data Analysis}

Differences in soil characteristics between the invaded and uninvaded plots were compared by means of paired t-tests. Additionally, a two-way ANOVA was done with site and vegetation type (invaded and uninvaded) as the fixed main effects for selected soil parameters. Pearson's correlation analysis was done with all sites pooled to determine relationships between the measured soil variables. Differences are reported as significant for tests with $P$-values $\leq 0.05$. All the parameters were analyzed with SAS Version 9.2 software. 


\subsection{Results and Discussion}

Despite increasing evidence for positive feedback between the exotic invasive species and soil, along with the ongoing challenges in successful management of exotic species in the south Florida Everglades, there are very few studies quantifying the impacts of exotic invasive species on ecosystem processes (See Gordon, 1998). The goal of this paper is to determine the soil factors influenced by L. microphyllum and to test whether the competitive advantage of L. microphyllum was due in part to nutrient sequestration and soil factors that might contribute to the suppression of native plant species. I compared soil from three different sites with contrasting soil characteristics and land use history; thus, the differences observed in soil measured soil parameters among these sites are in large part explained by this.

There was a clear contrast between the rhizosphere soils from the three sites (Table 4. 2; Table 4.3). All the study sites were acidic (soil $\mathrm{pH} 4.95-6.36$ ), but the sites in central Florida and at Tree Tops Park had lower soil $\mathrm{pH}$ compared to the sites at Jonathan Dickinson Park. Likewise, the soil texture differed among the sites; Jonathan Dickinson sites had sandy soils, while the soils in central Florida were clayey, and the soil at Tree 
Tops Park was sandy loam. Soil organic matter was highest at Tree Tops Park and was lowest at Jonathan Dickinson Park.

Impacts on the nutrient cycling process are considered the most prominent effects of invasive species in the ecosystem. In my study, several soil characteristics were significantly different between the invaded plots and non-invaded plots in all three sampling sites. Most notably, there were significant differences in the total soil Al, C, Ca, and OM\% at all three sites (Table 4.2). At all the sites, soils invaded by L. microphyllum had higher concentrations of $\mathrm{Al}, \mathrm{Ca}, \mathrm{C}$ and organic matter. Differences in the concentrations of $\mathrm{N}, \mathrm{P}, \mathrm{Zn}$, and $\mathrm{pH}$ were site-specific. Soils under native vegetation were generally more acidic; this was statistically significant at the central Florida and Jonathan Dickinson sites but was not statistically significant at the Tree Tops Park site. This indicates that the effect of L. microphyllum on soil characteristics is site-specific and depends on existing soil conditions. There was no significant difference in the $\mathrm{Cu}, \mathrm{Fe}, \mathrm{K}$, $\mathrm{Mg}$, and $\mathrm{Mn}$ concentrations under native vegetation and L. microphyllum at all the three sites (data not shown).

Plant species can change the soil microbial community structure and function with varying amount and quality of litter deposition (Ehrenfeld 2003; Kurtev et al. 2002), which, in turn, could influence the soil nutrient concentration under the native and invasive species. The bacteria population was significantly higher under the native species compared to L. microphyllum in two sites; the difference was not statistically significant at the central Florida site. On the other hand, the fungal population was significantly higher under L. microphyllum compared to the native plants at all three sites (Table 2). Further analysis on the type of microbes and the role of allelochemicals, which 
are reported to be an important determinant for invasive success of exotic plants (Bais et al. 2003), in regulating the soil microbial community structure is necessary, but my results provide some evidence that L. microphyllum could regulate the structure of soil microbial communities in its rhizosphere.

My results corroborate the results of Ehernfield (2003) and Callaway et al. (2004), where invasive plants enhance productivity and nutrient availability in invaded soils via an abundant litter deposition thus increasing their own success. Soil organic matter was strongly correlated to the available soil nutrients (Table 4.4) which indicates that the difference in the organic matter inputs to the soil under the natives and L. microphyllum could influence the difference in the nutrient availability. The most significant effects on soil characteristics were seen at sites with the lowest nutrient concentrations (Table 4.2). Additionally, the site effect was highly significant for all the soil parameters analyzed, indicating that L. microphyllum can adapt to and thrive in sites with a significant variation in nutrients as well as other soil characteristics. 
Table 0.4 Pearson's correlation coefficients between the selected soil parameters with all sites pooled.

\begin{tabular}{|c|c|c|c|c|c|c|c|c|c|c|}
\hline & $\mathrm{Al}$ & $\mathrm{C}$ & $\mathrm{Ca}$ & $\mathrm{N}$ & OM & $\mathrm{P}$ & $\mathrm{Zn}$ & $\mathrm{pH}$ & TBC & TFC \\
\hline $\mathrm{Al}$ & - & & & & & & & & & \\
\hline $\mathrm{C}$ & $\begin{array}{r}-0.171 \\
\mathrm{~ns}\end{array}$ & - & & & & & & & & \\
\hline $\mathrm{Ca}$ & $\begin{array}{r}-0.173 \\
\mathrm{~ns}\end{array}$ & $\begin{array}{r}\mathbf{0 . 8 9 2} \\
* * *\end{array}$ & - & & & & & & & \\
\hline $\mathrm{N}$ & $\begin{array}{r}-0.241 \\
\mathrm{~ns}\end{array}$ & $\begin{array}{r}0.894 \\
* * *\end{array}$ & $\begin{array}{r}0.792 \\
* * *\end{array}$ & - & & & & & & \\
\hline $\mathrm{OM}$ & $\begin{array}{r}-0.030 \\
*\end{array}$ & $\begin{array}{r}\mathbf{0 . 9 2 8} \\
* * *\end{array}$ & $\begin{array}{r}\mathbf{0 . 8 7 4} \\
* * *\end{array}$ & $\begin{array}{r}\mathbf{0 . 8 7 5} \\
* * *\end{array}$ & - & & & & & \\
\hline $\mathrm{P}$ & $\begin{array}{r}-0.099 \\
\mathrm{~ns}\end{array}$ & $\begin{array}{r}0.542 \\
* *\end{array}$ & $\begin{array}{r}0.571 \\
* *\end{array}$ & $\begin{array}{r}0.524 \\
* *\end{array}$ & $\begin{array}{r}0.433 \\
* *\end{array}$ & - & & & & \\
\hline $\mathrm{Zn}$ & $\begin{array}{r}0.255 \\
\mathrm{~ns}\end{array}$ & $\begin{array}{r}0.389 \\
*\end{array}$ & $\begin{array}{r}0.447 \\
* *\end{array}$ & $\begin{array}{r}0.325 \\
\text { ns }\end{array}$ & $\begin{array}{r}0.470 \\
* *\end{array}$ & $\begin{array}{r}-0.151 \\
\mathrm{~ns}\end{array}$ & - & & & \\
\hline $\mathrm{pH}$ & $\begin{array}{r}-0.385 \\
*\end{array}$ & $\begin{array}{r}-0.127 \\
\mathrm{~ns}\end{array}$ & $\begin{array}{r}-0.142 \\
\mathrm{~ns}\end{array}$ & $\begin{array}{r}-0.069 \\
\mathrm{~ns}\end{array}$ & $\begin{array}{r}-0.321 \\
\mathrm{~ns}\end{array}$ & $\begin{array}{r}0.457 \\
* *\end{array}$ & $\begin{array}{r}-0.716 \\
* * *\end{array}$ & - & & \\
\hline TBC & $\begin{array}{r}0.254 \\
\mathrm{~ns}\end{array}$ & $\begin{array}{r}0.463 \\
* *\end{array}$ & $\begin{array}{r}0.339 \\
*\end{array}$ & $\begin{array}{r}0.533 \\
* *\end{array}$ & $\begin{array}{r}0.651 \\
* * *\end{array}$ & $\begin{array}{r}-0.057 \\
\mathrm{~ns}\end{array}$ & $\begin{array}{r}0.469 \\
* *\end{array}$ & $\begin{array}{r}-0.632 \\
* * *\end{array}$ & - & \\
\hline TFC & $\begin{array}{r}0.776 \\
* * *\end{array}$ & $\begin{array}{r}0.190 \\
\mathrm{~ns}\end{array}$ & $\begin{array}{r}0.135 \\
\mathrm{~ns}\end{array}$ & $\begin{array}{r}0.029 \\
\mathrm{~ns}\end{array}$ & $\begin{array}{r}0.270 \\
\mathrm{~ns}\end{array}$ & $\begin{array}{r}-0.035 \\
\mathrm{~ns}\end{array}$ & $\begin{array}{r}0.524 \\
* *\end{array}$ & $\begin{array}{r}-0.432 \\
* *\end{array}$ & $\begin{array}{r}0.255 \\
\mathrm{~ns}\end{array}$ & - \\
\hline
\end{tabular}

Probability levels: *: $\mathrm{P}<0.05 ; * * \mathrm{P}<0.01 ; * * * \mathrm{P}<0.0001$. Coefficients higher than 0.75 are in bold.

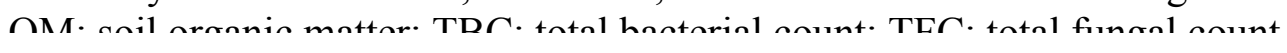


Overall, my results show increased mineral nutrient concentrations in the rhizosphere of L. microphyllum compared to the rhizosphere of adjacent native species. These results follow the general trend reported by various researchers, where the nutrient pools in the invasive species rhizosphere are significantly increased compared to the coexisting natives (Duda et al. 2003; Vanderhoven 2005; Dassonville et al. 2008; Liao et al. 2008; Perkins 2011). This effect was most evident at sites with lowest nutrient concentration. As reported by Ehrenfeld (2003) and Liao et al. (2008), this may be the direct effect of increased amounts of $\mathrm{C}$ and $\mathrm{N}$ added to the soil with higher litter input. Dassonville et al. (2008), have reported an opposite impact of invasive species in nutrient-poor versus nutrient-rich sites. Although any pre-existing differences in the plots with and without L. microphyllum cannot be disregarded with complete certainty, I believe that the differences in the soil characteristics between the invaded and uninvaded plots could be the result of difference in plant species in them. L. microphyllum invasion is still expanding and pre- and post invasion comparison could provide a better insight. Successful management of habitats invaded by exotic plant species requires a prior knowledge of whether the invaders have significantly altered the ecosystem (Walker and Smith 1997) because soil properties such as texture, $\mathrm{pH}$, and organic matter content influence herbicide efficiency and therefore control success. Along with the added organic matter, nutrients, and changes in the $\mathrm{pH}$ of the soil, other specific ecosystem process as outlined by Gordon (1998) could also be influenced by various exotic invasive species that create positive feedback for themselves and future invaders. Additionally, mechanisms such as production of allelochemicals, and changes in the microbial 
communities merit future research to achieve successful control of L. microphyllum and other exotic invasive species in the Everglades.

\section{Acknowledgement}

This research was supported by the Dissertation Evidence Acquisition Fellowship, to $\mathrm{PhD}$ candidate Pushpa Soti from the Graduate School, Florida International University. Helpful comments on the manuscript were made by, Suzanne Koptur, and Michael Sukop. I also thank Stewart T. Reed, USDA, ARS, Miami, Florida for his help in analyzing the samples

\section{References}

Bais, HP, Vepachedu R, Gilroy S, Callaway RM, Vivanco JM (2003) Allelopathy and exotic plant invasion: from molecules and genes to species interactions. Science, 301: 1377-1380.

Callaway RM, Ridenour WM (2004) Novel weapons: Invasive success and the evolution of increased competitive ability. Frontiers in Ecology and the Environment 2:436443.

Dassonville N, Vanderhoeven S, Vanparys V, Hayez M, Gruber W, Meerts P (2008) Impacts of alien invasive plants on soil nutrients are correlated with initial site conditions in NW europe. Oecologia 157:131-140.

Duda J J, Freeman DC, Emlen JM, Belnap J, Kitchen SG, Zak JC, Sobek E, Tracy M, Montante J (2003) Differences in native soil ecology associated with invasion of the exotic annual chenopod, Halogeton glomeratus. Biol. Fertility Soils 38:72-77.

Ehrenfeld JG (2010) Ecosystem consequences of biological invasions. Annual Review of Ecology, Evolution, and Systematics 41:59-80.

Ehrenfeld JG (2003) Effects of exotic plant invasions on soil nutrient cycling processes. Ecosystems 6:503-523. 
Evans R, Rimer R, Sperry L, Belnap J (2001) Exotic plant invasion alters nitrogen dynamics in an arid grassland. Ecol. Appl. 11:1301-1310.

Ferriter A, Pernas T (2006) An explosion in slow motion: Tracking the spread of Lygodium microphyllum in Florida. Wildland Weeds 9:7-9.

Gandiaga S, VolinJ, Kruger E, Kitajima K (2009) Effects of hydrology on the growth and physiology of an invasive exotic, Lygodium microphyllum (old world climbing fern). Weed Res. 49:283-290.

Gordon D R (1998) Effects of invasive, non-indigenous plant species on ecosystem processes: Lessons from Florida. Ecol. Appl. 8:975-989.

Hawkes CV, Belnap J, D’Antonio C, Firestone MK (2006) Arbuscular mycorrhizal assemblages in native plant roots change in the presence of invasive exotic grasses. Plant Soil 281:369-380.

Hawkes CV, Wren IF, Herman DJ, Firestone MK (2005) Plant invasion alters nitrogen cycling by modifying the soil nitrifying community. Ecol. Lett. 8:976-985.

Hoorens B, Aerts R, Stroetenga M (2003) Does initial litter chemistry explain litter mixture effects on decomposition? Oecologia 137:578-586.

Kourtev P, Ehrenfeld J, Häggblom M (2003) Experimental analysis of the effect of exotic and native plant species on the structure and function of soil microbial communities. Soil Biol. Biochem. 35:895-905.

Leary J, Hue N, Singleton P, Borthakur D (2006) The major features of an infestation by the invasive weed legume gorse (Ulex europaeus) on volcanic soils in Hawaii. Biol. Fertility Soils 42:215-223.

Ley RE, D'Antonio CM (1998) Exotic grass invasion alters potential rates of $\mathrm{N}$ fixation in Hawaiian woodlands. Oecologia 113:179-187.

Liao C, Peng R, Luo Y, Zhou X, Wu X, Fang C, Chen J, Li B (2008) Altered ecosystem carbon and nitrogen cycles by plant invasion: A meta-analysis. New Phytol. 177:706-714.

Mack MC, D'Antonio CM (1998) Impacts of biological invasions on disturbance regimes. Trends in Ecology \& Evolution 13:195-198.

Pemberton RW, Ferriter AP (1998) Old world climbing fern (Lygodium microphyllum), a dangerous invasive weed in Florida. Am. Fern J. 165-175. 
Perkins LB, Johnson DW, Nowak RS (2011) Plant-induced changes in soil nutrient dynamics by native and invasive grass species. Plant Soil 345:365-374.

Rice KJ, Emery NC (2003) Managing microevolution: Restoration in the face of global change. Frontiers in Ecology and the Environment 1:469-478.

Saggar S, McIntosh P, Hedley C, Knicker H (1999) Changes in soil microbial biomass, metabolic quotient, and organic matter turnover under Hieracium (H. pilosella L.). Biol. Fertility Soils 30:232-238.

Seeley Jr HW, VanDemark PJ (1962) Microbes in action. A laboratory manual of microbiology. Microbes in action. A laboratory manual of microbiology.

Sperry L, Belnap J, Evans R (2006) Bromus tectorum invasion alters nitrogen dynamics in an undisturbed arid grassland ecosystem. Ecology 87:603-615.

Storer DA (1984) A simple high sample volume ashing procedure for determination of soil organic matter. Communications in Soil Science \& Plant Analysis 15:759-772.

USEPA Method 3050 (1996) Acid digestion of sediments, sludges, and soils. Available at: <www.epa.gov/epaoswer/hazwaste/test/pdfs/3050b.pdf $>$.

Vanderhoeven S, Dassonville N, Meerts P (2005) Increased topsoil mineral nutrient concentrations under exotic invasive plants in Belgium. Plant Soil 275:169-179.

Vilà M, Espinar JL, Hejda M, Hulme PE, Jarošík V, Maron JL, Pergl J, Schaffner U, Sun Y, Pyšek P (2011) Ecological impacts of invasive alien plants: A meta-analysis of their effects on species, communities and ecosystems. Ecol. Lett. 14:702-708.

Volin JC, Kruger E L, Volin VC, Tobin MF, Kitajima K (2010) Does release from natural belowground enemies help explain the invasiveness of Lygodium microphyllum? A cross-continental comparison. Plant Ecol. 208:223-234.

Volin JC, Lott MS, Muss JD, Owen D (2004) Predicting rapid invasion of the Florida Everglades by old world climbing fern (Lygodium microphyllum). Divers. Distrib. 10:439-446.

Walker LR, Smith SD (1997) Impacts of invasive plants on community and ecosystem properties. Pages 69 - 86 in Assessment and management of plant invasions. Springer New York.

Yuan Y, Wang B, Zhang S, Tang J, Tu C, Hu S, Yong JW, Chen X (2012) Enhanced allelopathy and competitive ability of invasive plant Solidago canadensis in its introduced range. Journal of Plant Ecology. 


\title{
INFLUENCE OF SOIL BIOGEOCHEMICAL PROPERTIES ON EXOTIC INVASIVE LYGODIUM MICROPHYLLUM: A CROSS CONTINENT COMPARISON OF SOIL CHARACTERISTICS TO INVASION SUCCESS
}

\begin{abstract}
With the influence in the plant's ability to extract water and nutrients, soil characteristics play an important role in the distribution of plant species. The objective of this research was to analyze the soil characteristics associated with exotic invasive, Lygodium microphyllum, in its native range in Australia and the recipient habitat in south Florida. Rhizosphere soil samples from both the continents were analyzed for the soil physical, chemical and biological characteristics. The results from this study indicate that rhizosphere soil characteristics were very different in the two regions. Likewise, leaf nutrient status of this plant also varied in the two continents. The composition of mycorrhizal fungi, which is believed to aid this plant in the recipient habitat, was also very different with higher diversity in the disturbed sites compared to the undisturbed sites. The most important result was the Australian sites had a high concentration of aluminum and zinc which are phytotoxic in a highly acidic soil conditions compared to the Florida sites. Overall, my results indicate that L. microphyllum could be growing poorly in its native range in Australia because of the soil toxic effects associated with strong soil acidity and low foliar nitrogen concentration which in turn could affect the photosynthetic capacity of the plant. On the other hand, Jonathan Dickinson Park, which has the worst case of L. microphyllum infestation in Florida, provides a more favorable growth environment for this plant with well drained sandy, slightly acidic soils with low concentration of soil elements. This study highlights that along with the characteristics of
\end{abstract}


exotic plant species and native plant community, the understanding of invasive success of exotic plants needs the understanding of belowground community and ecology.

Key words: soil toxicity, habitat restoration, exotic invasive species, mycorrhizal fungi.

\subsection{Introduction}

Lygodium microphyllum (Old World climbing fern) is an invasive exotic plant species taking over many sites in freshwater and moist habitats across southern and central Florida. It is reported to have reached a "critical mass" of coverage and begun exponential rate of expansion, where the spread rate is higher than the management effort. Biannual surveys conducted by South Florida Water Management District estimate that this fern had doubled its coverage in just two years (FNPS 2005). Lygodium microphyllum does not have a high economic value in its native range, thus there is very little information available about its native ecology and the available information is mostly on its native herbivores. Very little is known about why this plant is invasive outside its native range (Ferriter 2001). It is reported to be found in a variety of habitats including freshwater creeks, perennial creeks, coastal depression wetlands, upland rainforests and sheltered canyons near permanent springs in its native range in Australia (Goolsby et al. 2003). It Asia, the fern is reported to occur in lowland rainforests in peat soils, coastal wetlands and in habitats dominated by wet clay soils (Goolsby et al. 2003).

In the invaded regions of south Florida L. microphyllum displays most of the ecological characteristic associated with successful invasive plants (Westbrooks 1998): it has the ability to grow in varying hydrological (Gandiaga et al. 2009), nutrient (Volin et al. 2010), and light conditions (Volin et al. 2004). It produces millions of spores all year 
round which can be transported by wind up to 30 miles; it tolerates a wide range of soil $\mathrm{pH}$ (Chapter 3); has a symbiotic relationship with arbuscular mycorrhizal fungi (AMF) (Chapter 2). Comparative analysis of soil samples from both its native range and invaded region have shown that L. microphyllum, which had adapted to close-to-neutral soils in Florida, grows in highly acidic soils in its native range in Australia (Chapter 2). Additionally the Food and Agriculture Organization (FAO) world soil distribution map shows the soil in the native habitats, identified by Goolsby et al. (2006), is a highly acidic region (Fig 5.1).

Soil $\mathrm{pH}$ has complex effect on plant growth leading to the variation in the distribution of plant species in acidic or calcareous soils. Diekmann and Lawesson (1999) reported that $\mathrm{pH}$ is one of the major underlying variables determining the floristic variation within forests. The major growth limiting factors associated with acid soil infertility include toxicities of aluminum and manganese, and deficiencies or low availability of certain essential elements including calcium, magnesium, phosphorus and molybdenum (Foy 1984). These factors may directly restrict plant growth or indirectly restrict plant growth through interference in the development and functioning of symbiotic associations with rhizobia, mycorrhizas and actinomycetes. It is reported that Al toxicity as a result of strong acidic soils have a detrimental effect in plant growth by lowering rooting depth, increasing susceptibility to drought and decreased uptake of subsoil nutrients. Plants exposed to Al toxicity are reported to have stunted growth, small dark green leaves, and late maturity, the root tips and lateral roots are thickened. They have many stubby lateral roots but lack in fine branching, thus, inefficient in absorbing nutrients and water (Kochian et al. 2004, and references there in). Similarly, soil texture 
is also an important factor influencing the distribution of minerals, organic matter and microbial community and other soil properties (Scott and Robert 2006). Along with soil $\mathrm{pH}$, soil texture plays an important role in controlling the mobility of elements in the soil, with the mobility of metals being highest in acidic coarse-textured soils (McBride 1994). Likewise, soils which are sandy or better drained have extensive fine roots compared to clay soils. Volin et al. (2010) indicated that the growth of L. microphyllum was highest in sandy soils which indicate that this plant prefers well drained sandy soils. Furthermore, the root and rhizome growth of L. microphyllum was highest in the sandy soils of south Florida compared to the native Australian soils (Volin et al. unpublished data).

Most of the research on exotic invasive species is focused on the traits that enhance the probability such as high growth rate, short lifecycle, high levels of resource allocation to reproduction, and flexible utilization of available environmental resources, of a particular species being a successful invader in a recipient community. There are several studies with biogeographic comparison of invasive species in their native range and invaded range focusing on the impact of variable soil microbes on plant performance (Callaway and Aschehoug 2000; Hierro et al 2005; Vermeij et al. 2009; Volin et al. 2010). However, there are no studies conducted comparing the soil element status and its effect on plant growth in the native and recipient habitat.

I conducted a cross continent comparison of soil characteristics associated with $L$. microphyllum. Here, I present evidence that the invasion by L. microphyllum in south Florida is not only facilitated by the soil microbial community but also by the soil chemical characteristics. In this paper I suggest that invasive plants not only escape from their natural herbivores but also the toxic soil environment in their native habitats. 


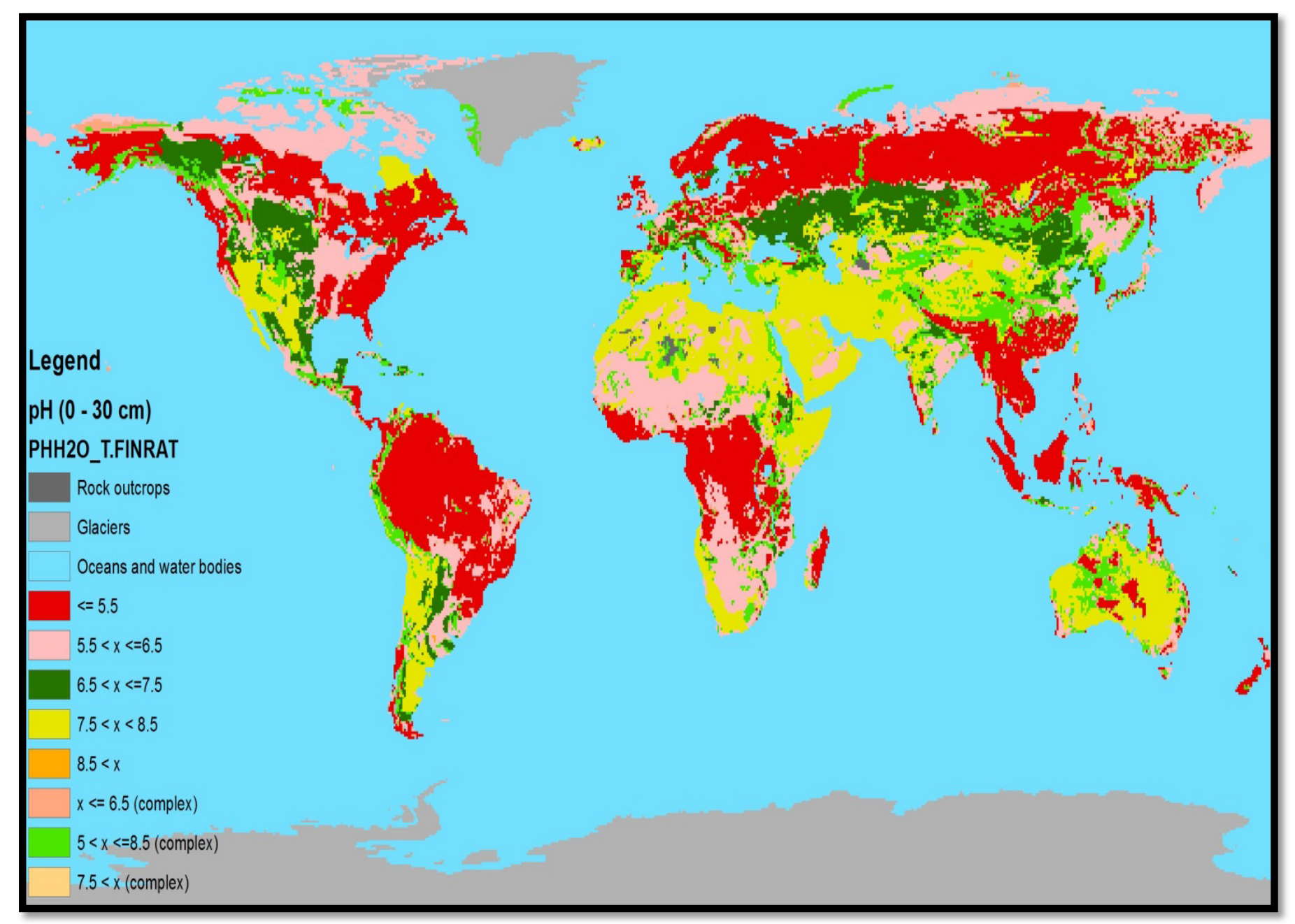

Fioure 01 World snil nH man data source ISR IC.-Wise world dataset 


\subsection{Methods}

\subsubsection{Sites and sample collection}

I compared soil samples collected from three different sites in Australia, where the plant is native, and the invaded sites in Florida. Sampling dates and site information are given in Table 5.1. The soil samples were collected during the dry season in both the continents except for the central Florida site, which was added later, because of its unique characteristics. At each sampling site, six $1 \mathrm{~m} \times 1 \mathrm{~m}$ plots were selected randomly and soil from the 10-15 cm deep zone was collected from all four corners and the center of each plot with a soil corer (diameter: $18 \mathrm{~mm}$ ) and mixed homogeneously into one bulk sample for each plot. The soil samples from south Florida were transported to the laboratory in a cooler. Samples from Australia and central Florida were stored in $4^{\circ} \mathrm{C}$ and shipped overnight.

\subsubsection{Soil nutrient analysis}

Small portion of each soil sample was air dried, passed through a $2 \mathrm{~mm}$ sieve for analysis of physicochemical properties. They were then ground to fine powder with a mortar and pestle, and stored at room temperature in air-tight containers for further analysis of nutrients and trace elements. The soil $\mathrm{pH}$ was measured with a $\mathrm{pH}$ meter, (soil solution ratio 1:2 in water), texture was measured by the hydrometer method, total organic matter was measured based on the standard loss on ignition method $\left(500^{\circ} \mathrm{C}, 5\right.$ hours; Storer 1984). Total C and N in soil and leaves were measured with a Truspec CN analyzer. Total $\mathrm{Ca}, \mathrm{Fe}, \mathrm{Al}, \mathrm{Mg}, \mathrm{K}, \mathrm{Mn}$ and $\mathrm{P}$ in soil were measured with an $\mathrm{ICP}-\mathrm{MS}$ at USDA, ARS Laboratory, Miami, Florida after following the acid digestion Method 
3050B (USEPA 1996). One gram of finely ground soil samples were transferred to large glass tubes and mixed with $10 \mathrm{ml}$ of $30 \% \mathrm{HNO}_{3}$. The tubes were covered with a vapor recovery system and heated to $95 \pm 5^{\circ} \mathrm{C}$ and refluxed for 10 minutes without boiling under the hood in a heating block maintained with a Partlow Mic 6000 Profile Process Controller.

Table 0.1 Sampling sites, dominant vegetation and date of sample collection for the two continents.

\begin{tabular}{cccc}
\hline Site & Coordinates & Dominant vegetation & Sample date \\
\hline Tree Tops Park, FL, & $26^{\circ} 4^{\prime} 0.04^{\prime \prime N}$, & Royal fern & Dec, 2010 \\
US & $80^{\circ} 16^{\prime} 5.88^{\prime \prime} \mathrm{W}$ & & \\
Central Florida & $28^{\circ} 23^{\prime} 4.03^{\prime \prime} \mathrm{N}$ & Royal fern & June 2012 \\
US & $81^{\circ} 44^{\prime} 41.30^{\prime \prime} \mathrm{W}$ & & \\
Jonathan Dickinson, & $27^{\circ} 0^{\prime} 37.33^{\prime \prime} \mathrm{N}$, & Slush pine & Dec, 2010 \\
FL, US & $80^{\circ} 7^{\prime} 20.28^{\prime \prime} \mathrm{W}$ & & \\
& & & \\
Daintree Ferry, & $16^{\circ} 15^{\prime} 25.57^{\prime \prime S}$, & Drynaria & June, 2011 \\
Queensland, AU & $145^{\circ} 24^{\prime} 3.94 " \mathrm{E}$ & & June, 2011 \\
Logan Reserve, & $27^{\circ} 40^{\prime} 4.16^{\prime \prime S}$, & Bungwall fern & \\
Queensland, AU & $153^{\circ} 16^{\prime} 0.44^{\prime \prime} \mathrm{E}$ & & June, 2011 \\
Nudgee, & $27^{\circ} 22^{\prime} 31.12^{\prime \prime S}$, & Melaleuca & \\
Queensland, AU & $153^{\circ} 5^{\prime} 39.42^{\prime \prime E}$ & & \\
\hline
\end{tabular}

After cooling to $40^{\circ} \mathrm{C} 5 \mathrm{ml}$ of concentrated $\mathrm{HNO}_{3}$ was added and the sample was heated again until no brown fumes were given off. After cooling to $40^{\circ} \mathrm{C}, 2 \mathrm{ml}$ of DI 
water and $3 \mathrm{ml}$ of $30 \% \mathrm{H}_{2} \mathrm{O}_{2}$ was added and heated until the effervescence subsided. The samples were cooled and diluted to $50 \mathrm{ml}$ with DI water, centrifuged at $2000 \mathrm{rpm}$ for 10 minutes and filtered with a Whatman No. 41 filter paper.

\subsubsection{Microbial analysis: bacteria and fungi population}

The total colony forming units (CFU) of bacteria and fungi was determined by the standard spread plate dilution method as described by Seely and VanDemark (1981). Dry equivalent of one gram soil was mixed in $9 \mathrm{ml}$ sterile water (autoclaved) and was diluted serially. Samples were vigorously mixed during dilution to assist in dislodging the bacteria from the soil particles. A serial dilution of $10^{-2}, 10^{-3}, 10^{-4}$, and $10^{-5}$ was made for fungi and $10^{-4}, 10^{-5}, 10^{-6}$, and $10^{-7}$ for bacteria. A total of $100 \mu 1$ of diluted soil suspension was spread on three plates per soil sample for both bacteria and fungi at each dilution level. Nutrient agar containing cycloheximide solution (to prevent fugal growth) was used for bacteria and Rose Bengal Agar (RBA) with streptomycine sulphate (to prevent bacteria growth) was used for the estimation fungal colonization. Sterilized water was spread on the agar plates were used as control. Inoculated plates were incubated at $26^{\circ} \mathrm{C}$ for 3 days before the colonies were counted. Dilution plates with 100 to 300 colonies per plate were counted.

\subsubsection{Mycorrhizal spore identification}

Results from previous chapters indicate that the mycorrhizal root colonization in L. microphyllum is significantly higher in the invaded regions compared to the native regions in Australia. I further identified the mycorrhizal spores in the rhizosphere soil of 
L. microphyllum in both the regions following the wet sieving technique (Gerdemann and Nicolson 1963). $100 \mathrm{ml}$ of DI water was added to dry equivalent of $50 \mathrm{~g}$ of soil from each site. It was then mixed vigorously to separate the spores from soil aggregates. The mixture was washed through a series of sieves ( $2 \mathrm{~mm}, 100 \mu \mathrm{m}$ and $32 \mu \mathrm{m})$. Washing was done until the water flowing through the sieves was clear. The sievate retained on the sieves was washed and centrifuged with water to remove floating organic debris and the supernatant was discarded. The pellet in the bottom was re-suspended in a $50 \%$ sucrose solution, and centrifuged for one minute at 2000 RPM to separate the spores from denser soil components. Immediately after centrifugation, spores in the sucrose supernatant were rinsed in a fine sieve to remove the sucrose. The spores were then washed into a filter paper for vacuum filtration. The fungal spores were then mounted on slides for taxonomic identification to the genus level based on the spore morphology and wall characteristics, using the descriptions by the International Culture Collection of Arbuscular and Vesicular-Arbuscular Mycorrhizal Fungi (http:// invam.caf.wvu.edu). The genus that was dominant was taken as the representative mycorrhizal AMF type for each site. 


\subsubsection{Statistical analysis}

Analysis of variance (ANOVA) was done to compare the difference in the soil and leaf nutrient status of L. microphyllum among the different sites in the two continents. Linear regression with Pearson's correlation analysis and was done with all sites pooled to determine relationship between the measured soil variables. Differences are reported as significant for tests with $P$-values $\leq 0.05$. All the parameters were analyzed with SAS Version 9.2 software.

\section{3 Results}

\subsubsection{Soil texture}

Soil texture, shown in Table 5.2, varied significantly among the different sites. Soil in Jonathan Dickenson was dominantly sand (98\% sand), sandy loam in Tree Tops, sandy clay loam in Logan, loam in Nudgee, silt loam in Daintree and clay in Central Florida.

\subsubsection{Nutrient analysis}

My results indicate a significant variation in the soil properties in the recipient habitat in Florida and native range in Australia (Table 5.3). The native range in Australia had strong acidic soil ranging from $\mathrm{pH}=4.1$ at Nudgee to $\mathrm{pH}=4.55$ at Logan. The Florida sites had significantly higher soil $\mathrm{pH}$ ranging from 5.60 at Tree Tops Park to 6.57 at Jonathan Dickinson Park. Soil Al concentration was highest at the Central Florida site followed by Logan and Nudgee in Australia. Soil C\% and organic matter \% was highest in Tree Tops park followed by Logan, C\% was lowest in Daintree while organic matter \% 
was lowest in Jonathan Dickinson. Total $\mathrm{Cu}$ ranged from $43.94 \mu \mathrm{g} \mathrm{g}^{-1}$ in Daintree to 1.84 $\mu \mathrm{g} \mathrm{g}^{-1}$ in Jonathan Dickinson, there was no significant difference among the other four sites. Total Fe was also highest in Daintree in Australia: $15.86 \mathrm{mg} \mathrm{g}^{-1}$ and lowest in Jonathan Dickinson $0.54 \mathrm{mg} \mathrm{g}^{-1}$. Total $\mathrm{K}$ in soil was also highest in Daintree $\left(1.77 \mathrm{mgg}^{-1}\right)$ and Logan (1.49) while there was no significant difference among the other sites. The Australian sites and Central Florida site had significantly lower level of $\mathrm{N}$ compared to the Tree Tops and Jonathan Dickinson sites. Total Mg in soil was highest in Logan (1.27 $\left.\mathrm{mg} \mathrm{g}^{-1}\right)$ followed by Tree Tops Park $\left(0.68 \mathrm{mg} \mathrm{g}^{-1}\right)$ and was lowest in Central Florida $(0.20$ $\left.\mathrm{mg} \mathrm{g}^{-1}\right)$. Total soil $\mathrm{Mn}$ was also highest in Daintree $\left(0.27 \mathrm{mg} \mathrm{g}^{-1}\right)$ while there was no significant difference among other five sites. N\% in the soil was highest in Tree Tops $(1.27 \%)$ followed by Logan $(0.71 \%)$, and Jonathan Dickinson $(0.49 \%)$. There was no significant difference in the total $\mathrm{P}$ level among all the sites. Logan had highest concentration of $\mathrm{Zn}$ in the soil $\left(37.80 \mu \mathrm{g} \mathrm{g}^{-1}\right)$ followed by Daintree $\left(27.91 \mu \mathrm{g} \mathrm{g}^{-1}\right)$ and Tree Tops $\left(23.21 \mu \mathrm{g} \mathrm{g}^{-1}\right)$

\subsubsection{Bacteria and fungi population}

The average counts of bacteria and fungi, colony forming units CFU per gram of $1 \mathrm{~g}$ dry soil, was significantly different in all the sites (Table 5.3). The CFU of bacteria and fungi was influenced by soil texture. Total colony forming units of bacteria was highest in Daintree $\left(288 \times 10^{7}\right)$ and lowest in Jonathan Dickinson $\left(43.83 \times 10^{7}\right)$ and there was no significant difference in the population in the other four sites. Likewise, the total colony forming units of fungi was also highest in Daintree $\left(123.5 \times 10^{3}\right)$ while there was no significant difference among the other five sites. Correlation analysis indicated that, 
there was no relationship between the soil organic matter, total carbon on the soil bacteria and fungal population, however there a strong relationship with the soil texture. There was a strong negative relationship between the sand content in the soil and the CFU of bacteria $(\mathrm{r}=-0.62 ; \mathrm{p}<0.0001)$ and fungi $(\mathrm{r}=-0.67 ; \mathrm{p}<0.0001)$ on the other hand there was strong positive relationship with the silt content in the soil (bacteria: $r=0.76 ; \mathrm{p}<$ 0.0001 and fungi: $r=0.75 ; \mathrm{p}<0.0001)$. Surprisingly the bacteria population had a negative relationship with the soil $\mathrm{pH}(\mathrm{r}=-0.57 ; \mathrm{p}=0.0003)$ while the fungi had no relationship with the soil $\mathrm{pH}$.

\subsubsection{AMF spores}

The spore composition based on the morphology was different among the six sampling sites. Spores of different sizes and colors were present in all sites. Highest morphological diversity was a seen in Tree Tops followed by Central Florida, and the lowest diversity was seen in Jonathan Dickinson. Glomus was found in all the locations but was dominant in Nudgee, Logan and central Florida; Scutellospora was dominant in Tree Tops, and Jonathan Dickinson; and Gigaspora in Daintree (Fig. 5.2). 


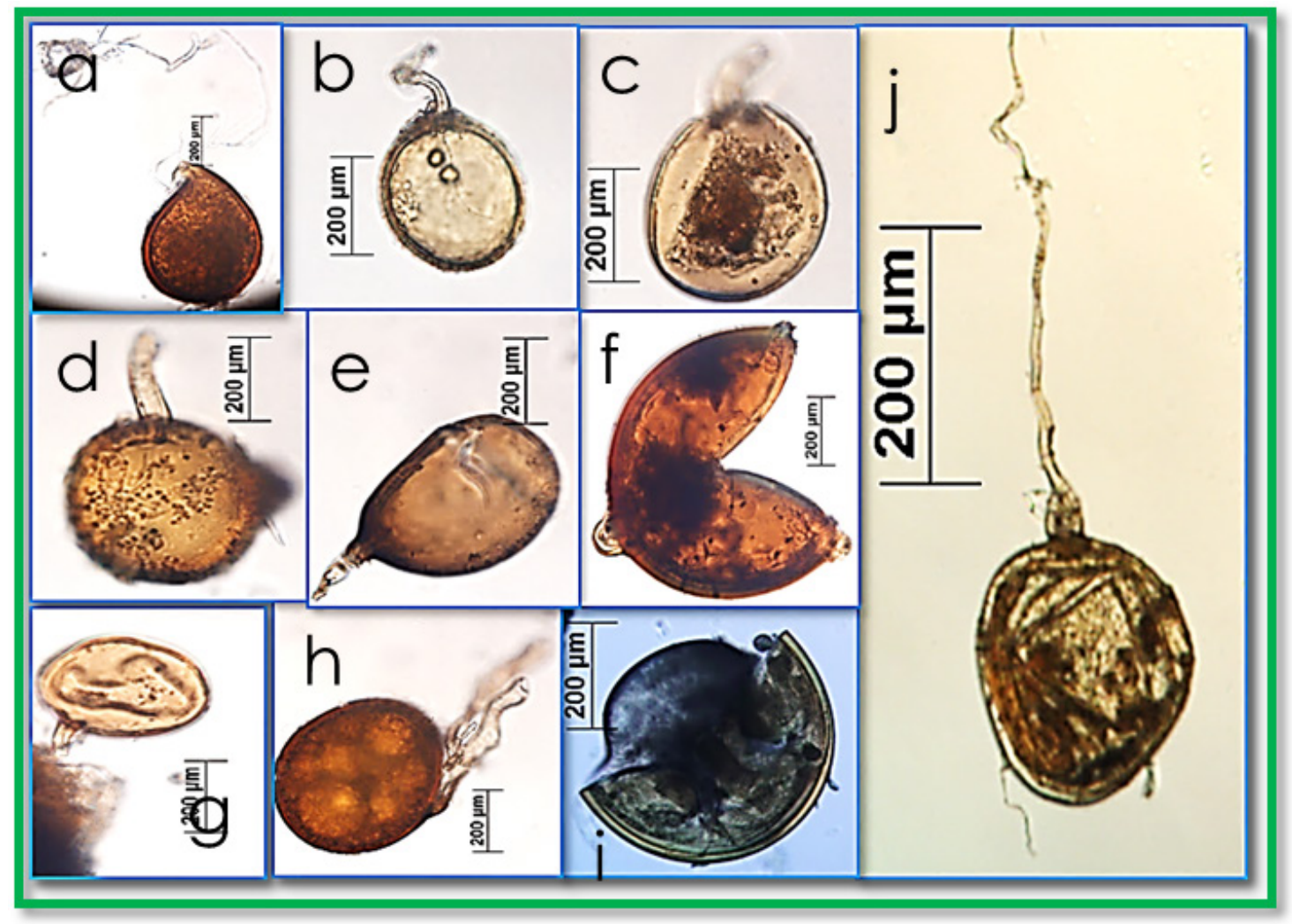

Figure 0. 2 AMF morphotypes extracted from the rhizosphere soil of L. microphyllum in the two continents. Glomus sp. spore (a, e, f); Gigaspora sp. with the bulbous sporangeneous cell $(\mathrm{h}, \mathrm{j})$; Scutellospora sp. showing the germination shield (b, d, g, i). 
Table 0. 2 Soil texture and mean \pm standard error of the means of total colony forming units (counts $\times 107$ ) of bacteria; (count $\times$ $10^{3}$ ) of fungi per gram of soil in the invaded and native sites.

\begin{tabular}{|c|c|c|c|c|c|c|}
\hline Site & Soil Texture & Sand \% & Silt \% & Clay $\%$ & $\begin{array}{c}\text { CFU of Bacteria } \mathrm{g}^{-1} \\
\text { soil }\end{array}$ & $\begin{array}{l}\text { CFU of Fungi } \\
\mathrm{g}^{-1} \text { soil }\end{array}$ \\
\hline $\begin{array}{c}\text { Tree Tops Park, FL, } \\
\text { US }\end{array}$ & Sandy loam & 78 & 16.5 & 5.5 & $143.66(13.00)$ & $73.83(12.27)$ \\
\hline $\begin{array}{c}\text { Central Florida } \\
\text { US }\end{array}$ & Clay & 13 & 40 & 47 & $152.5(16.42)$ & $61.16(9.82)$ \\
\hline $\begin{array}{c}\text { Jonathan Dickinson, } \\
\text { FL, US }\end{array}$ & Sand & 98 & 2 & 0 & $43.83(8.13)$ & $46.66(7.76)$ \\
\hline $\begin{array}{l}\text { Daintree Ferry, } \\
\text { Queensland, AU }\end{array}$ & Silt loam & 25 & 57.5 & 17.5 & $288(16.56)$ & $123.5(13.63)$ \\
\hline $\begin{array}{l}\text { Logan Reserve, } \\
\text { Queensland, AU }\end{array}$ & $\begin{array}{l}\text { Sandy clay } \\
\text { loam }\end{array}$ & 67.5 & 20 & 12.5 & $103.83(10.12)$ & $50.5(8.75)$ \\
\hline $\begin{array}{c}\text { Nudgee, } \\
\text { Queensland, AU }\end{array}$ & Loam & 50 & 32.5 & 17.5 & $153.5(6.15)$ & $49(4.60)$ \\
\hline
\end{tabular}


Table 5.3 Mean (Std. Dev.) of the selected soil chemical characteristics in the native sites in Australia and invaded sites in Florida

\begin{tabular}{|c|c|c|c|c|c|c|}
\hline Variable & Central Florida (FL) & Daintree (AU) & $\begin{array}{l}\text { Jonathan Dickinson } \\
\text { (FL) }\end{array}$ & Logan (AU) & Nudgee (AU) & Tree Tops (FL) \\
\hline $\mathrm{Al}\left(\mathrm{mg} \mathrm{g}^{-1}\right)$ & $5.07(0.61) \mathrm{a}$ & $2.14(0.30) \mathrm{b}$ & $0.8(0.07) \mathrm{c}$ & $2.55(0.07) \mathrm{b}$ & $2.35(0.11) \mathrm{b}$ & $1.38(0.37) \mathrm{d}$ \\
\hline $\mathrm{C} \%$ & $4.03(0.84) \mathrm{a}$ & $2.70(0.44) \mathrm{a}$ & $3.02(1.88) \mathrm{a}$ & $12.90(2.43) b$ & $4.28(1.19) \mathrm{a}$ & $22.43(4.15) \mathrm{c}$ \\
\hline $\mathrm{Ca}\left(\mathrm{mg} \mathrm{g}^{-1}\right)$ & $0.41(0.13) \mathrm{a}$ & $0.47(0.11) a$ & 3.35 (1.77)a & $0.43(0.25) \mathrm{a}$ & $0.09(0.01) \mathrm{a}$ & $17.21(6.31) b$ \\
\hline $\mathrm{Cu}\left(\mu \mathrm{g} \mathrm{g}^{-1}\right)$ & $8.42(2.81) a$ & $43.94(12.31) b$ & $1.84(0.54) \mathrm{c}$ & $10.16(0.57) \mathrm{a}$ & $6.74(1.57) \mathrm{a}$ & $14.76(4.02) \mathrm{a}$ \\
\hline $\mathrm{Fe}\left(\mathrm{mg} \mathrm{g}^{-1}\right)$ & $2.92(1.78) \mathrm{ad}$ & $15.86(2.96) \mathrm{b}$ & $0.54(0.25) \mathrm{a}$ & $8.34(1.10) \mathrm{c}$ & $5.38(1.86) \mathrm{ac}$ & $4.46(1.91) \mathrm{d}$ \\
\hline $\mathrm{K}\left(\mathrm{mg} \mathrm{g}^{-1}\right)$ & $0.16(0.10) a$ & $1.77(0.35) b$ & $0.09(0.05) \mathrm{a}$ & $1.49(0.30) b$ & $0.12(0.02) \mathrm{a}$ & $0.18(0.05) \mathrm{a}$ \\
\hline $\operatorname{Mg}\left(\mathrm{mg} \mathrm{g}^{-1}\right)$ & $0.20(0.10) \mathrm{a}$ & $0.55(0.18) b$ & $0.21(0.11) \mathrm{a}$ & $1.27(0.17) \mathrm{c}$ & $0.25(0.05) \mathrm{a}$ & $0.68(0.27) \mathrm{b}$ \\
\hline $\operatorname{Mn}\left(\mathrm{mg} \mathrm{g}^{-1}\right)$ & $0.02(0.01) \mathrm{a}$ & $0.27(0.14) \mathrm{b}$ & $0.02(0.01) \mathrm{a}$ & $0.02(0.00) \mathrm{a}$ & $0.04(0.00) \mathrm{a}$ & $0.05(0.03) \mathrm{a}$ \\
\hline $\mathrm{N} \%$ & $0.20(0.26) \mathrm{a}$ & $0.18(0.03) \mathrm{a}$ & $0.49(0.10) b$ & $0.71(0.04) b$ & $0.26(0.10) a$ & $1.27(0.17) \mathrm{c}$ \\
\hline OM $\%$ & 8.65 (1.09)a & $8.07(2.89) \mathrm{a}$ & $4.32(0.90) \mathrm{a}$ & $35.50(7.04) b$ & $11.45(4.71) \mathrm{a}$ & $44.42(2.71) \mathrm{c}$ \\
\hline$P\left(\mathrm{mg} \mathrm{g}^{-1}\right)$ & $1.03(0.25)$ & $0.91(0.16)$ & $1.15(0.09)$ & $1.16(0.05)$ & $0.97(0.06)$ & $1.22(0.16)$ \\
\hline $\mathrm{Zn}\left(\mu \mathrm{g} \mathrm{g}^{-1}\right)$ & $15.93(8.25) \mathrm{a}$ & $27.91(5.63) \mathrm{a}$ & $8.77(1.86) \mathrm{b}$ & $37.80(12.43) \mathrm{c}$ & $14.28(3.77) \mathrm{a}$ & $23.21(4.53) \mathrm{a}$ \\
\hline $\mathrm{pH}$ & $5.77(0.12) \mathrm{a}$ & $4.24(0.15) b$ & $6.57(0.10) c$ & $4.55(0.14) \mathrm{d}$ & $4.01(0.05) \mathrm{e}$ & $5.60(0.06) \mathrm{a}$ \\
\hline
\end{tabular}

Note: values in the same row followed by different letters represent significant difference at $\mathrm{p}<0.05$. 


\subsubsection{Leaf nutrient status}

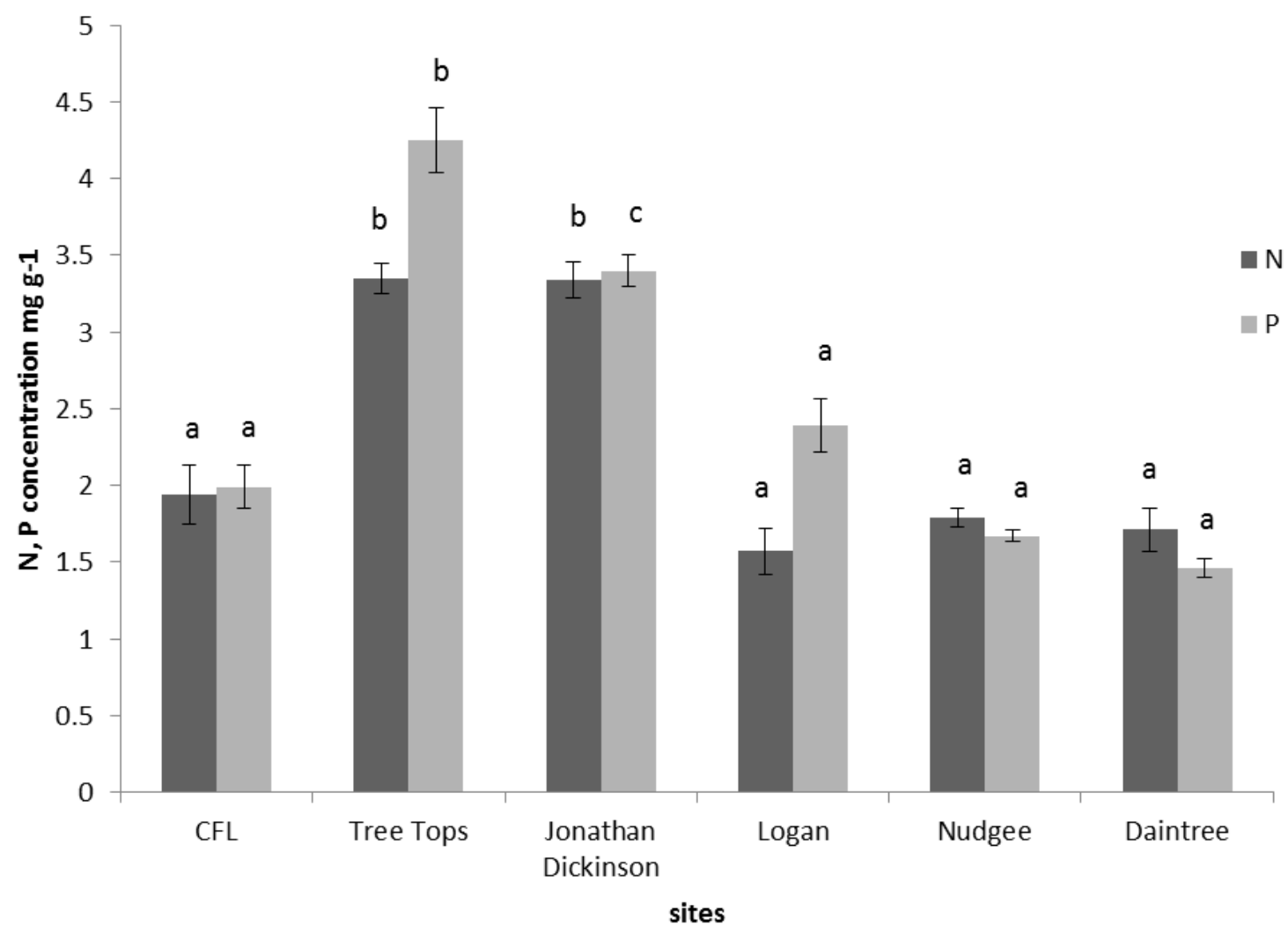

Figure 0.3 Nutrient concentration in the leaves (Mean $\pm \mathrm{S}$ E) of L. microphyllum collected from different sites. For $\mathrm{N}$ and $\mathrm{P}$ separately, different letters indicate significant differences in leaf concentration of $\mathrm{N}$ and $\mathrm{P}(\mathrm{P}<0$ 05; Tukey's test $)$.

There was a significant positive correlation between the leaf $\mathrm{N}$ concentration and soil $\mathrm{C}(\mathrm{r}=0.48 ; \mathrm{p}=0.003) ; \mathrm{Ca}(\mathrm{r}=0.63 ; \mathrm{p}<0.0001) ; \mathrm{N}(\mathrm{r}=0.50 ; \mathrm{p}=0.002) ; \mathrm{P}(\mathrm{r}=\mathrm{pH}$ $(\mathrm{r}=0.71 ; \mathrm{p}<0.0001)$; sand $\%(\mathrm{r}=0.65 ; \mathrm{p}<0.0001)$. Likewise leaf $\mathrm{P}$ concentration had a negative correlation with soil $\mathrm{Al}(\mathrm{r}=-0.47 ; \mathrm{p}=0.1013) ; \mathrm{Cu}(\mathrm{r}=-0.34 ; \mathrm{p}=0.04) ; \mathrm{Fe}(\mathrm{r}=$ $0.49 ; \mathrm{p}=0.002) ; \mathrm{K}(\mathrm{r}=-0.40 ; \mathrm{p}=0.01) ;$ silt $(\mathrm{r}=-0.65 ; \mathrm{p}<0.0001)$ and clay $\%(\mathrm{r}=-0.55$ 
$\mathrm{p}=0.0005$ ). There was a significant positive correlation between leaf $\mathrm{P}$ concentration and soil C\% ( $\mathrm{r}=0.75 ; \mathrm{p}<0.0001) ; \mathrm{Ca}(\mathrm{r}=0.82 ; \mathrm{p}<0.0001) ; \mathrm{N} \%(\mathrm{r}=0.81 ; \mathrm{p}<0.0001) ; \mathrm{OM} \%$ $(\mathrm{r}=0.54 ; \mathrm{p}=0.0006) ; \mathrm{P}(\mathrm{r}=0.54 ; \mathrm{p}=0.0006) ; \mathrm{pH}(\mathrm{r}=0.64 ; \mathrm{p}<0.0001)$ and sand $\%(\mathrm{r}=0.73$; $\mathrm{p}<0.0001)$.

\subsection{Discussion}

My goal was to determine if there was significant difference in the soil characteristics in the native and recipient habitats of $L$. microphyllum. There was a significant difference in the soil chemical, biological as well as physical characteristics in the two regions. These soil characteristics can, on their own or in association with other habitat features, promote the extensive growth of L. microphyllum in its recipient habitat in Florida. There was also a significant difference in the foliar nutrient concentration among the sites. My results show soil texture and $\mathrm{pH}$ to be the major factors influencing L. microphyllum growth.

My results show that $L$. microphyllum has adapted to nutrient poor highly acidic soils in its native range and invades slightly acidic soils in Florida. Along with strongly acidic conditions, the Australian soils have high concentration of Al, which is considered phytotoxic in strongly acidic soils. Acidic soil conditions are reported to enhance the presence of trivalent cation $\left(\mathrm{Al}^{3+}\right)$, the most toxic form of $\mathrm{Al}$ available to plants (Delhaaize and Ryan 1995; Lidon and Barreiro 2002; Kochian et al. 2005). My Central Florida site, where L. microphyllum was growing over sand mine spoil, had the highest concentration of Al. However this was not a restricting factor for L. microphyllum which could be because of the soil $\mathrm{pH}$. Al toxicity in plants is widely studied in crop plants, 
according to Kochian (1995), Al toxicity causes alterations of physiological and biochemical process of plants and consequently in their productivity. Plant species differ in their $\mathrm{Al}$ tolerance, but given that L. microphyllum grown in Australian soil had lower biomass allocation to the belowground structures (rhizomes and roots) compared to the plants grown in Florida soils (Volin et al. unpublished data), my results indicate the possibility of the "evolution of increased competitive ability hypothesis". When $L$. microphyllum escaped the highly acidic soil environment to the sites in Jonathan Dickinson sandy sites, the plants could have evolved with lowered investment cost to defense and reallocation of the resources to growth and reproduction, increasing their colonizing success.

Even with varying soil nitrogen status, foliar $\mathrm{N}$ concentration was significantly higher in all south Florida plants compared to the Australian plants. Leaf N concentration is directly related to increase in relative growth rate (RGR) and photosynthetic capacity leading to increased plant productivity and litter decomposition in L. microphyllum (Chapter 3) and several other plant species (Vitousek 2004; Treseder 2008; Vitousek 2010; Chen et al. 2011). This could in part explain the higher growth of L. microphyllum in south Florida invaded areas compared to its native range in Australia. Similar results of higher nutrient concentration in the Florida plants compared to the Australian plants have been reported by Goolsby et al. (2006). Lygodium microphyllum is reported to be highly mycorrhizal in south Florida compared to its native range in Australia (Chapter 2), this higher degree of mycorrhizal colonization could play a role in the increased foliar $\mathrm{N}$ concentration. 
Various soil and plant factors cause a significant influence in the soil microbial community, which have a fundamental role in nutrient cycling, plant growth and root health. It is widely reported that the rhizosphere community of different plant species growing in the same soil are distinct. Likewise an individual plant species scan harbor different microbial communities in different soil types. A strong effect of soil texture on bacteria and fungi population was evident in this study. Daintree, in Australia with the highest percentage of silt harbored highest CFUs of bacteria and fungi, while Jonathan Dickinson in Florida with $98 \%$ sand had the lowest CFUs of bacteria and fungi. This kind of influence of soil texture on the structure of microbial population has been reported previously (Garbeva et al. 2004; Fang et al. 2005). An unexpected result was: the bacteria and fungi population remained uninfluenced by the soil organic matter, $\mathrm{C} \%$ or soil $\mathrm{pH}$ which indicates a possible difference in the litter quality and secondary metabolites produced by the plant in its native range and invaded community.

My results indicate that L. microphyllum had a symbiotic relationship with multiple species of AMF depending on the site conditions. My two sites, Central Florida and Tree Tops which had higher diversities of spores are relatively disturbed sites compared to the other sites which had lower diversity of spores. This is an expected result and is in line with the Intermediate Disturbance Hypothesis (IDH) (Huston, 1979) which suggests that a less disturbed healthy ecosystem has lower diversity of arbuscular mycorrhizal fungi. I found that Glomus, which is reported to be the dominant and most abundant genus of AMF, was present in all sites but dominated in Logan and Nudgee in Australia and Central Florida sites. Scutellospora was dominant in Jonathan Dickinson, which has the worst case of L. microphyllum infestation in Florida and in the Tree Tops 
Park. This indicates the influence of soil texture in the composition of AMF species in the soil. Even though spore morphology has been used to identify AMF species, it has been reported that this technique is not sufficient (Kruger et al. 2009). This study provides evidence that the mycorrhizal fungi composition is different in the native and recipient habitats along with the soil characteristics, but an in-depth analysis with the use of molecular technique is necessary to identify the AMF species and their relationship with L. microphyllum.

Overall, this study provides baseline information on the variation in the rhizosphere soil characteristics of L. microphyllum in its native and recipient habitat. My results indicate that $\mathrm{Al}$ sensitivity could be a determining factor that restricts the growth of L. microphyllum in the highly acidic soils rich in $\mathrm{Al}$ in its native range in Australia. Further research is necessary to gain an insight on the Al tolerance level of $L$. microphyllum and the role of $\mathrm{Al}$ concentration in soil in the growth limitation of $L$. microphyllum. I found that there was significant difference in the microbial populations and types in the regions, but I was not able to determine the specific roles of these microbes. However, these results are in line with the conclusion of Volin et al. (2010) who reported that escape from pathogenic soil microbial community could in part explain the extensive growth of L. microphyllum in the recipient habitats of Florida. My results indicate that L. microphyllum can be growing poorly in its native range in Australia because of the soil toxic effects associated with soil acidity and low foliar nitrogen concentration which in turn could affect the photosynthetic capacity of the plant. 


\section{References}

Callaway RM, Aschehoug E T 2000 Invasive plants versus their new and old neighbors: a mechanism for exotic invasion. Science, 290(5491), 521-523.

Chen FL, Jiang B, Zhang K, Zheng H, Xiao Y, Ouyang ZY, Tu NM 2011 Relationships between initial chemical composition of forest leaf litters and their decomposition rates in degraded red soil hilly region of Southern China. The journal of applied ecology. 22(3), 565 .

Delhaize E, Ryan PR 1995. Aluminum toxicity and tolerance in plants. Plant Physiol. 107,315-321.

Diekmann M, Lawesson JE 1999. "Shifts in ecological behaviour of herbaceous forest species along a transect from northern Central to North Europe." Folia Geobotanica 34.1: 127-141.

Fang M, Kremer RJ, Motavalli PP, Davis G 2005 Bacterial diversity in rhizospheres of nontransgenic and transgenic corn. Applied and environmental microbiology, 71(7), 4132-4136.

Ferriter A 2001 Lygodium management plan for Florida: a report from the Florida Exotic Pest Plant Council's Lygodium Task Force. Florida Exotic Pest Plant Council,

Foy CD 1984. Physiological effects of hydrogen, aluminum, and manganese toxicities in acid soil. In: Soil Acidity and Liming. Adams, F. (ed.). American Society of gronomy, Inc., Madison, WI. pp. 57-97.

Gandiaga S, Volin JC, Kruger EL, Kitajima K 2009 Effects of hydrology on the growth and physiology of an invasive exotic, Lygodium microphyllum (Old World climbing fern). Weed Res.; 49:283-290.

Garbeva P, Van Veen JA, Van Elsas JD 2004 Microbial diversity in soil: selection of microbial populations by plant and soil type and implications for disease suppressiveness. Annu. Rev. Phytopathol., 42, 243-270.

Gerdemann JW, Nicolson TH, 1963 Spores of mycorrhizal Endogone species extracted from soil by wet-sieving and decanting. Trans. Br. Mycol. Soc., 46: 235-244 Goolsby JA, Wright AD, Pemberton RW 2003 Exploratory surveys in Australia and Asia for natural enemies of Old World climbing fern, Lygodium microphyllum: Lygodiaceae. Biological Control 28.1: 33-46.

Hierro JL, Maron JL, Callaway RM 2005 A biogeographical approach to plant invasions: the importance of studying exotics in their introduced and native range. Journal of Ecology, 93(1), 5-15. 
Huston M 1979 A general hypothesis of species diversity. American naturalist, 81-101.

Kochian LV 1995 Cellular mechanisms of aluminum toxicity and resistance in plants. Annual review of plant biology, 46(1), 237-260.

Kochian LV, Hoekenga OA, Piñeros MA 2004 How do crop plants tolerate acid soils? Mechanisms of aluminum tolerance and phosphorous efficiency. Annu. Rev. Plant Biol. 55: 459-493.

Kochian LV, Pineros MA, Hoekenga OA 2005. The physiology, genetics and molecular biology of plant aluminum resistance and toxicity. Plant Soil 274, 175 - 195.

Krüger M, Stockinger H, Krüger C, Schüßler A 2009 DNA-based species level detection of Glomeromycota: one PCR primer set for all arbuscular mycorrhizal fungi. New Phytologist, 183(1), 212-223.

Lidon F, Barreiro M 2002. An overview into aluminum toxicity in maize. Bulg. J. Plant Physiol. 28, 96-112.

McBride MB 1995 Toxic metal accumulation from agricultural use of sludge: are USEPA regulations protective? Journal of Environmental Quality, 24(1), 5-18.

Scott BJ, Naiman RJ 2006 Soil texture and nitrogen mineralization potential across a riparian toposequence in a semi-arid savanna. Soil Biology and Biochemistry, 38(6), 1325-1333.

Seeley Jr H W, VanDemark P J 1962 Microbes in action. A laboratory manual of microbiology. Microbes in action. A laboratory manual of microbiology.

Storer D 1984 A Simple High Sample Volume Ashing Procedure for Determination of Soil Organic-Matter. Commun.Soil Sci.Plant Anal. ;15:759-772.

Treseder, KK 2008 Nitrogen additions and microbial biomass: A meta-analysis of ecosystem studies. Ecology Letters, 11(10), 1111-1120.

USEPA Method 30501996 Acid digestion of sediments, sludges, and soils. Available at: $<$ www.epa.gov/epaoswer/hazwaste/test/pdfs/3050b.pdf $>$.

Vermeij MJA, Smith TB, Dailer ML, Smith C M 2009 Release from native herbivores facilitates the persistence of invasive marine algae: a biogeographical comparison of the relative contribution of nutrients and herbivory to invasion success. Biological invasions, 11(6), 1463-1474. 
Vitousek, P. M. 2004. Nutrient cycling and limitation: Hawai'i as a model system. Princeton 476 University Press, Princeton, NJ.

Vitousek, P. M., S. Porder, B. Z. Houlton, and O. A. Chadwick. 2010 Terrestrial phosphorus 480 limitation: mechanisms, implications, and nitrogen-phosphorus interactions. Ecological 481 Applications 20:5-15.

Volin J, M Lott, J Muss, D Owen 2004 Predicting rapid invasion of the Florida Everglades by old world climbing fern (Lygodium microphyllum). Divers. Distrib. ;10:439-446.

Volin JC, EL Kruger, VC Volin, MF Tobin, K Kitajima 2010 Does release from natural belowground enemies help explain the invasiveness of Lygodium microphyllum? A crosscontinental comparison. Plant Ecol. ;208:223-234.

Westbrooks R 1998 Invasive plants, changing the landscape of America: fact book. Federal Interagency Committee for the Management of Noxious and Exotic Weeds (FICMNEW), Washington, D.C. 


\section{CONCLUSIONS AND RECOMMENDATIONS}

This study was conducted to determine why Lygodium microphyllum becomes a strong competitor in all hydrological, nutrient, light gradient habitats in south Florida compared to its native range in Australia. The studies presented in this dissertation provide baseline information and help to understand the complex feedbacks between exotic invasive species, soil microbial community and soil elements. I tested the hypothesis that the biogeochemical properties of Florida soils provide a more favorable condition for this species in the invaded region in Florida than in its native range. I did a cross-continent comparison of rhizosphere soil properties to determine if there were any specific characteristics in the soil which promote the invasiveness of this plant species in Florida.

Based on the results presented in the second chapter, L. microphyllum appears to be a strong host for arbuscular mycorrhizal fungi. However, this relationship with AMF varied with location, most probably by site hydrological conditions. Lygodium microphyllum had a stronger association with AMF in the dry areas of invaded regions in Florida compared to the flooded sites in Florida as well as its native range in Australia. The enhanced mycorrhizal fungi are also likely responsible for the greater $\mathrm{P}$ uptake and biomass accumulation in the control study. This strong association with mycorrhizae and an extensive belowground rhizome growth could in part explain efficient nutrient uptake leading to the competitiveness of L. microphyllum in nutrient poor Florida soils.

The green house study in the third chapter indicates that L. microphyllum is able to survive and grow in a wide range of soil $\mathrm{pH}$; however, final biomass, relative growth rate, photosynthesis and specific leaf area were all significantly greater in soil $\mathrm{pH} 5.5$ - 
6.5 compared to the other treatments. Correspondingly, nitrogen concentration was also significantly related to these four plant parameters. Additionally root colonization by mycorrhizal fungi was significantly higher in soil $\mathrm{pH}$ 5.5-7.5 and lowest in plants growing in 4.5 or 8.0. Arbuscular mycorrhizal fungi colonization in roots was significantly correlated with plant growth parameters and nutrient concentration in the leaves. Comparison of soil characteristics in the invaded and uninvaded sites in three different locations in the fourth chapter shows that even after removal the effect of $L$. mcirophyllum may persist leaving behind a "legacy" influencing the belowground ecology. It causes a slight increase in soil $\mathrm{pH}$, increase in soil organic matter and changes the ratio of bacteria and fungi population in the soil. This can have long-term effects on the restoration of the invaded sites or sites difficult or challenging for management. Cross continent soil characteristics comparison in the fourth chapter show that L. microphyllum can be growing poorly in its native range in Australia because of the soil toxic effects associated with soil acidity and low foliar nitrogen concentration which in turn could affect the photosynthetic capacity of the plant. Plant species differ in their Al tolerance, my results indicate the possibility of the "evolution of increased competitive ability hypothesis". When L. microphyllum escaped the highly acidic soil environment to the sites in Jonathan Dickinson sandy sites the plants could have evolved with lowered investment cost to defense and reallocation of the resources to growth and reproduction, increasing their colonizing success. This study documents that that L. microphyllum can allocate up to $40 \%$ of the total biomass to the rhizomes, which remain unaffected by the different control techniques. Thus, L. microphyllum immediately regenerates from the 
rhizomes after the use of management techniques such as fire, chemical spray, burning or cutting.

Overall, the results of this study could provide broader understanding in the ability of L. microphyllum being equally competitive in different habitat types in Florida. This study highlights that along with the characteristics of exotic plant species and native plant community, the understanding of invasive success of exotic plants needs the understanding of belowground community and ecology. It also provides information applicable for land managers responsible for protecting the Everglades, developing a sustainable control program towards minimizing the impacts of L. microphyllum as well as other exotic invasive species. Based on this study I recommend the following issues to be addressed in future studies:

- Lygodium microphyllum can form a very strong symbiotic relationship with AMF in its introduced environment in Florida. It is likely that this relationship is strongly influenced by site hydrological conditions, but this hypothesis needs to be tested in future research, especially when the Florida Everglades is undergoing a major hydrological shift as an effort for restoration. Future studies should also look into the possibilities of developing an integrated management plan which targets the micorrhizal fungi in the roots and rhizosphere of L. microphyllum.

- Prescribed burning, which causes a temporary rise in soil $\mathrm{pH}$, is a widely used method to control L. microphyllum, but my study shows that L. microphyllum could be benefiting from the slight increase in soil $\mathrm{pH}$ resulting from fire as well as the release of nutrients that are associated with burning. Further 
research should be done to determine the effect of fire on the mycorrhizal fungi and in soil with various $\mathrm{pH}$ levels.

- In my study, L. microphyllum had highest growth at neutral soil $\mathrm{pH}$ 's and began to show a significant decrease at a soil $\mathrm{pH}$ of 8.0 , likely further growth reductions would happen in even more alkaline soils. Thus, raising soil $\mathrm{pH}$ may be a possible management option to explore in the future, but increasing the soil $\mathrm{pH}$ would need to be studied carefully for its potential adverse effects to native flora as well, including both native plants and soil microorganisms.

- My results indicate that L. microphyllum recruits different species of AMF in different sites. This relationship of L. microphyllum with AMF merits further research. In-depth analysis with the use of molecular technique is necessary to identify the AMF species and their relationship with L. microphyllum.

Finally, exotic species invasion will be a continuous threat to the Everglades ecosystem and will continuously challenge land managers and researchers. With the increased rate and number of exotic species invasion, herbicide treatment will most likely become the widely used technique to control invasive species in the future. But, the effort of invasive species control should not ignore the belowground effects of invasive plants in the Florida Everglades ecosystem, especially when it is undergoing a major hydrological shift as an effort for restoration. Understanding the soil nutrient and microbial dynamics will provide opportunities to develop a successful integrated management technique. I believe a complete understanding of the soil ecosystem is necessary before adopting a management technique to achieve a successful long-term invasive species management strategy in the south Florida Everglades. 


\section{VITA}

\section{PUSHPA GAUTAM SOTI}

B.Sc, Environment Management

Pokhara University

Kathmandu, Nepal

2004

M. Sc. Environment Management

Pokhara University

Kathmandu, Nepal

2008

M.S., Environment Science

Florida Atlantic University

Boca Raton, Florida

$2006-2008$

Teaching Assistant

Florida Atlantic University

Boca Raton, Florida

$2008-2013$

Doctoral Candidate

Florida International University

Miami, Florida

Teaching Assistant

Florida International University

Miami, Florida

\section{PEER REVIEWED PUBLICATIONS}

Soti, P.G. and J.C. Volin. 2010. Does water hyacinth (Eichhornia crassipes) compensate for simulated defoliation? Implications for effective biocontrol. Biological Control 54: $35-40$.

Soti PG, Jayachandran K, Purcell M, Volin JC, and Kitajima K, (2013) Mycorrhizal Symbiosis and Lygodium microphyllum Invasion in South Florida- a Biogeographic Comparison. Symbiosis (In Review).

Soti Pushpa G., K Jayachandran, S Koptur, and JC Volin (2013) Effect of soil pH on growth, nutrient uptake, and mycorrhizal colonization in exotic invasive Lygodium microphyllum Biological Invasions (In Review). 
Soti Pushpa G., Jayachandran Krish (2013) Altered soil biogeochemical properties by exotic invasive Old World climbing fern (Lygodium microphyllum) in Florida: implications for management and restoration. Weed Science (In Review).

Boglaienko D., P. Soti, K. G. Shetty and K Jayachandran (2013) Buckwheat as a Cover Crop in Florida: Mycorrhizal Status and Soil Analysis. Journal of Sustainable Agriculture (In Review)

\section{POSTERS \& PRESENTATIONS}

Soti PG, Jayachandran K, Purcell M, Volin JC, and Kitajima K , (2013) Mycorrhizal Symbiosis and Lygodium microphyllum Invasion in South Florida- a Biogeographic Comparison. FLEPPC/SE-EPPC Joint Annual Conference, May 20-23, 2013, Panama City Beach, FL.

Soti Pushpa G., K Jayachandran, S Koptur, and JC Volin (2013) Effect of soil pH on growth, nutrient uptake, and mycorrhizal colonization in exotic invasive Lygodium microphyllum. Plant Biologists of South Florida, April 13, 2013, Miami FL

Soti Pushpa G., K Jayachandran (2013) Effect of soil pH on growth, nutrient uptake and mycorrhizal colonization in exotic invasive Lygodium microphyllum. Agroecology Symposium at FIU, March 4, 2013.

Soti Pushpa G., K Jayachandran (2013) Do soil geochemical properties promote exotic species invasion in Florida? A cross continent comparison. Department of Earth and Environment, Graduate Research Symposium, February 15, 2013.

Soti PG, Jayachandran K (2012) Soil Bio-geochemical Properties Associated with Exotic Species Invasion in Florida: A Cross Continent Comparison. Graduate Student Research Symposium, April 11, 2012.

Soti Pushpa G., K Jayachandran (2010) Influence of Soil Biogeochemical Properties on the Invasiveness of Old World Climbing Fern (Lygodium microphyllum). Environmental Studies Graduate Seminar, November 3, 2010.

Soti Pushpa G., K Jayachandran (2010) Role of mycorrhizal fungi in supporting invasiveness of Old World Climbing Fern in south Florida natural areas. Greater Everglades Ecosystem Restoration, The Greater Everglades: A Living Laboratory Change - Planning, Policy, and Science Meeting, July 12-16, 2010, Naples, FL. 